NATIONAL LABORATORY

MANAGED BY UT-BATTELLE

FOR THE DEPARTMENT OF ENERGY

\title{
High Performance Homes That Use 50\% Less Energy Than the DOE Building America Benchmark Building
}

\author{
January 2011
}

Prepared by

Jeff Christian
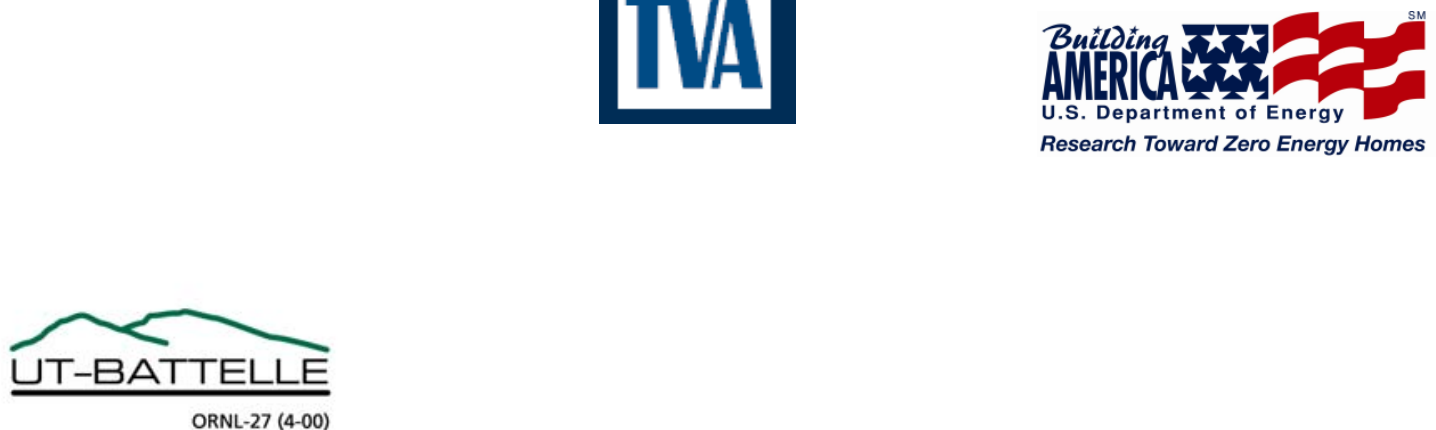


\section{DOCUMENT AVAILABILITY}

Reports produced after January 1, 1996, are generally available free via the U.S. Department of Energy (DOE) Information Bridge.

Website http://www.osti.gov/bridge

Reports produced before January 1, 1996, may be purchased by members of the public from the following source.

National Technical Information Service

5285 Port Royal Road

Springfield, VA 22161

Telephone 703-605-6000 (1-800-553-6847)

TDD 703-487-4639

Fax 703-605-6900

E-mail info@ntis.gov

Website http://www.ntis.gov/support/ordernowabout.htm

Reports are available to DOE employees, DOE contractors, Energy Technology Data Exchange (ETDE) representatives, and International Nuclear Information System (INIS) representatives from the following source.

Office of Scientific and Technical Information

P.O. Box 62

Oak Ridge, TN 37831

Telephone 865-576-8401

Fax 865-576-5728

E-mail reports@osti.gov

Website http://www.osti.gov/contact.html

This report was prepared as an account of work sponsored by an agency of the United States Government. Neither the United States Government nor any agency thereof, nor any of their employees, makes any warranty, express or implied, or assumes any legal liability or responsibility for the accuracy, completeness, or usefulness of any information, apparatus, product, or process disclosed, or represents that its use would not infringe privately owned rights. Reference herein to any specific commercial product, process, or service by trade name, trademark, manufacturer, or otherwise, does not necessarily constitute or imply its endorsement, recommendation, or favoring by the United States Government or any agency thereof. The views and opinions of authors expressed herein do not necessarily state or reflect those of the United States Government or any agency thereof. 
Building Technologies Research and Integration Center

\section{HIGH PERFORMANCE HOMES THAT USE 50\% LESS ENERGY THAN THE DOE BUILDING AMERICA BENCHMARK BUILDING}

Prepared by OAK RIDGE NATIONAL LABORATORY

Oak Ridge, Tennessee 37831-6283

managed by

UT-BATTELLE, LLC

for the

U.S. DEPARTMENT OF ENERGY

under contract DE-AC05-00OR22725 



\section{CONTENTS}

Page

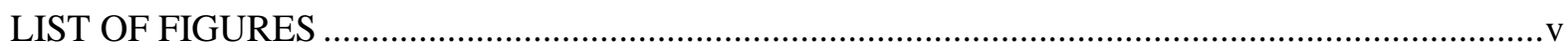

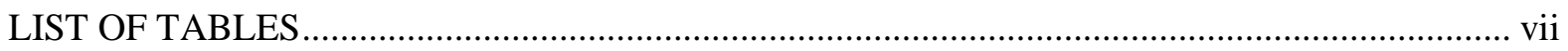

ABBREVIATIONS, INITIALISMS, AND ACRONYMS ….......................................................ix

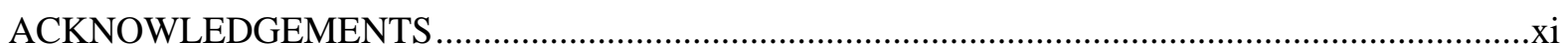

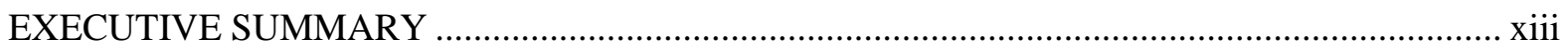

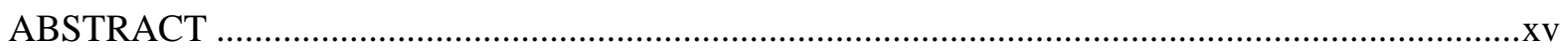

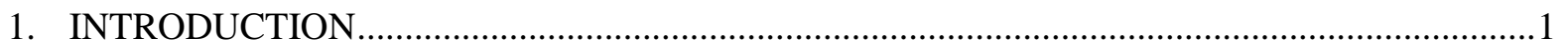

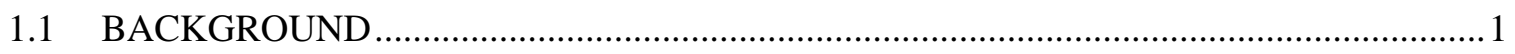

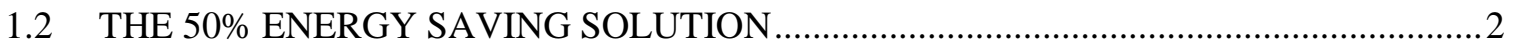

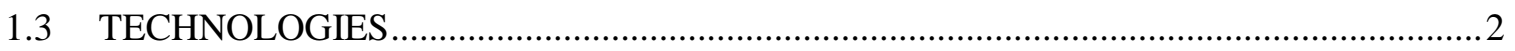

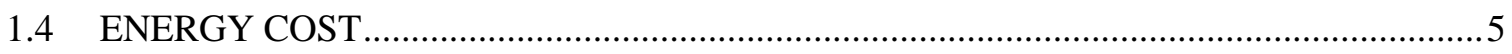

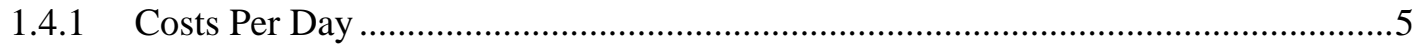

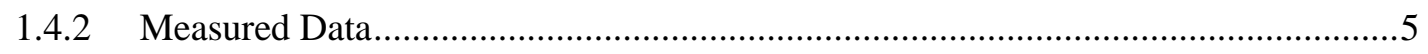

1.5 ENERGY SAVINGS-ZEH5 VS. BUILDING AMERICA BENCHMARK.......................

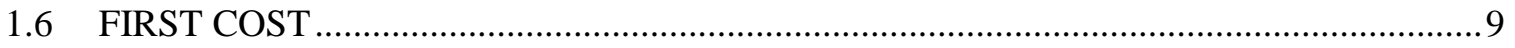

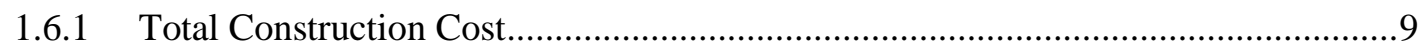

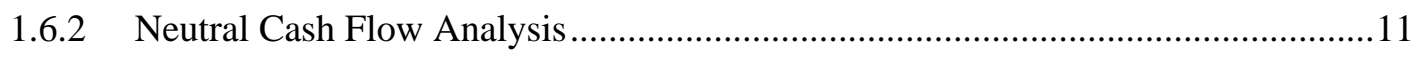

2. FLOOR PLANS, CROSS SECTIONS, AND ELEVATIONS …...........................................15

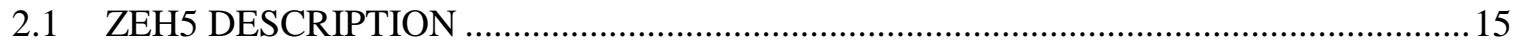

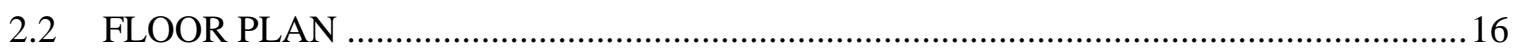

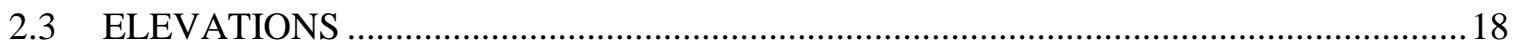

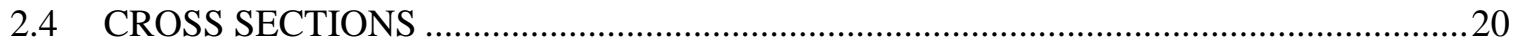

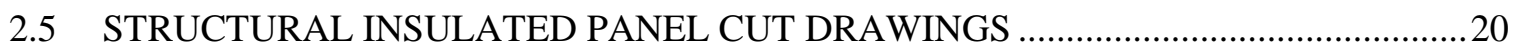

3. SITE CHARACTERIZATION AND HOUSE ORIENTATION ..............................................29

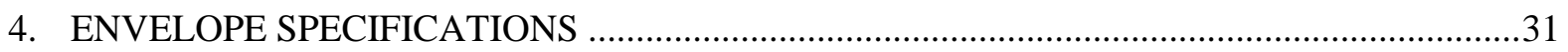

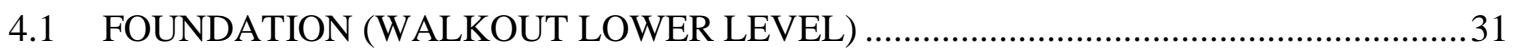

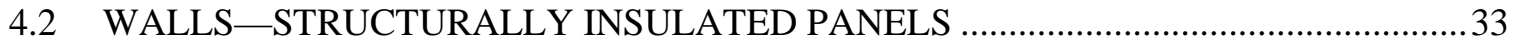

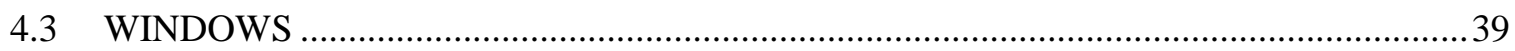

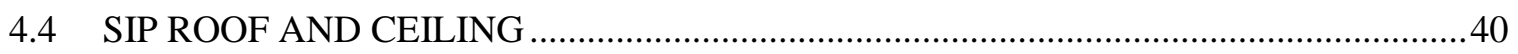

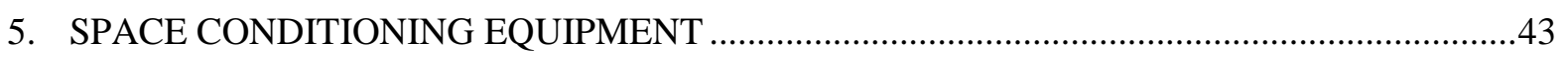

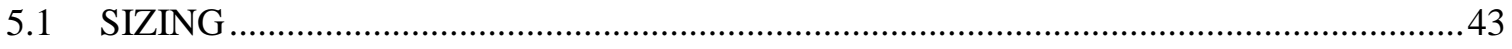

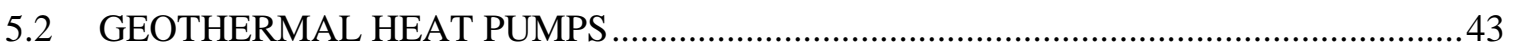




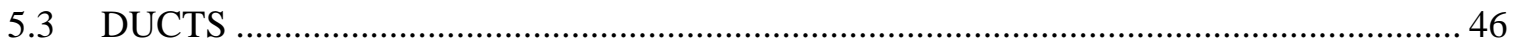

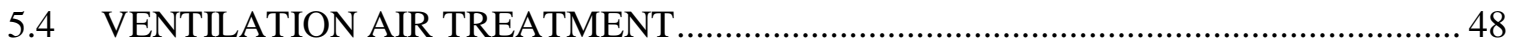

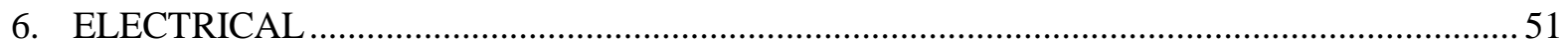

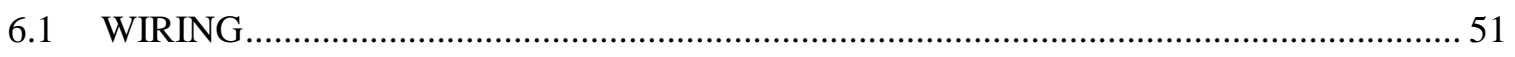

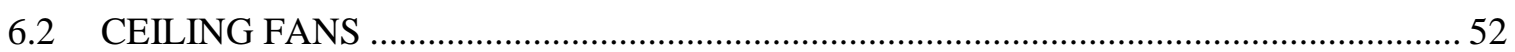

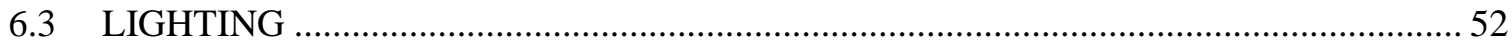

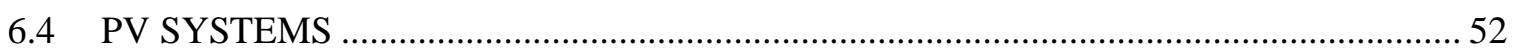

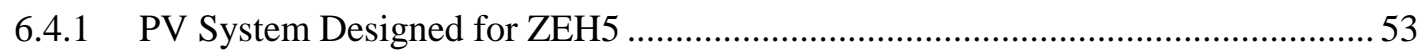

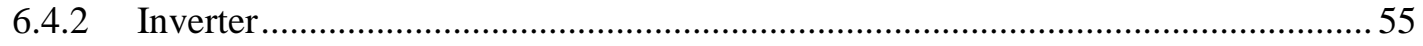

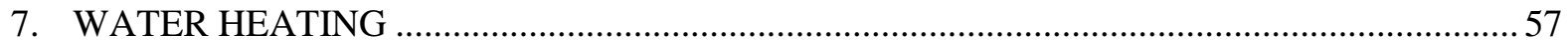

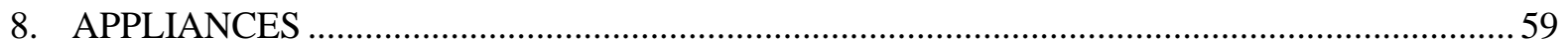

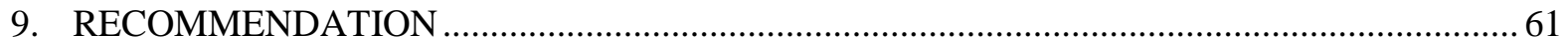

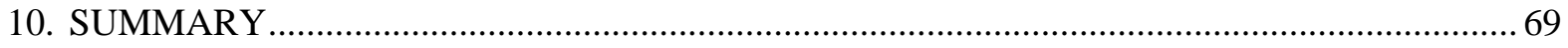

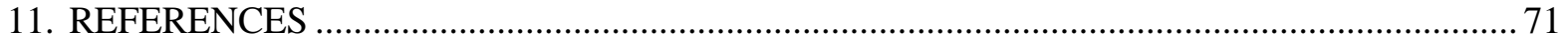

APPENDIX A: GEOTHERMAL HEAT PUMP PERFORMANCE ISSUES AND

ASSOCIATED DATA …................................................................................... A

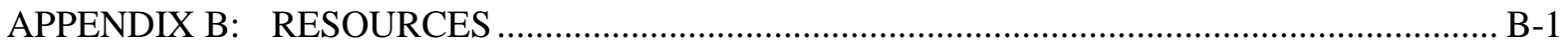




\section{LIST OF FIGURES}

Figure

Page

1 Layout of Harmony Heights development with five high performance houses ............... 1

2

Annual energy consumption and solar production of ZEH5 .5

East elevation of ZEH5 from the street................................................................ 15

Structural insulated panels (SIPs) for ZEH5 come numbered to match the panel cut drawings

Before the metal roofing is installed, 2 in. of XPS is laid directly on top of the

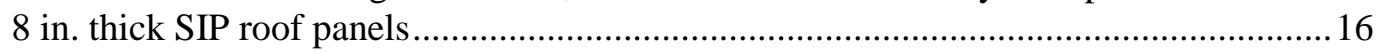

Solar water heater collectors and the $11 \mathrm{~W}$ PV panel to power a $12 \mathrm{~V}$ DC pump............16

Top floor plan of ZEH5

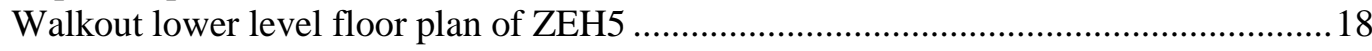

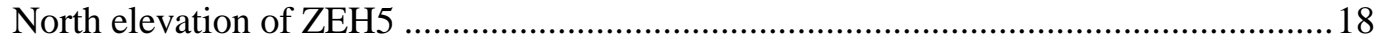

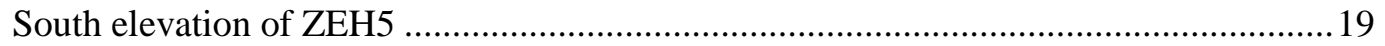

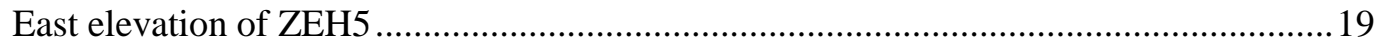

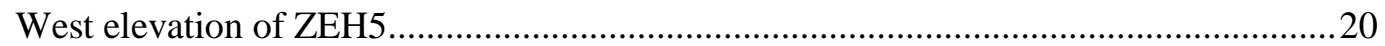

Longitudinal section through ZEH5; floor plan shown in Fig. 7 ................................21

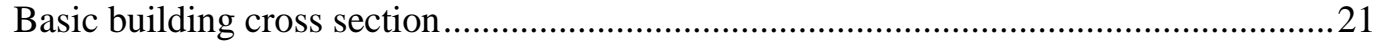

Panel layout of the north (wall 3) and south (wall 1) walls ............................................22

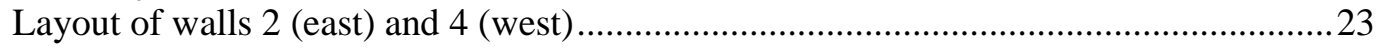

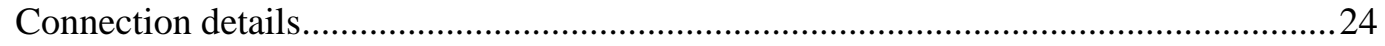

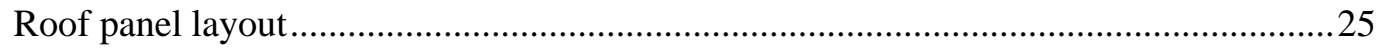

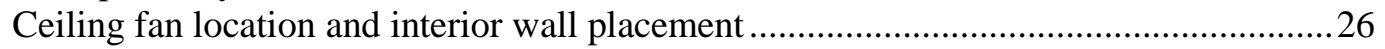

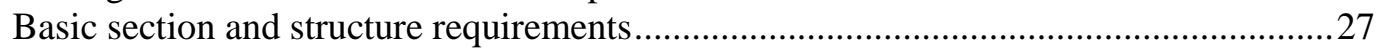

ZEH5 foundation detail, Eason Architects, 2007 .......................................................... 31

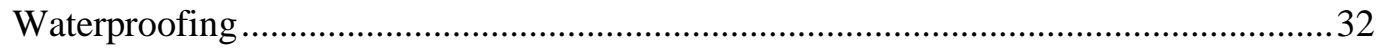

Installation of $4 \times 8 \mathrm{ft}$ fiberglass boards sized to cover the waterproofing ....................... 32

Detailing around inset windows to avoid thermal shorts and minimize water

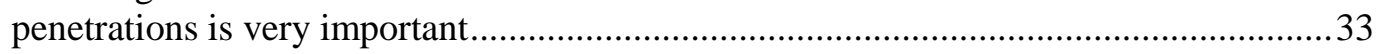

25 The above-grade portion of the foundation wall receiving final spray covering .............33

26 Footer drains run to daylight on both sides of the wall below the walkout lower

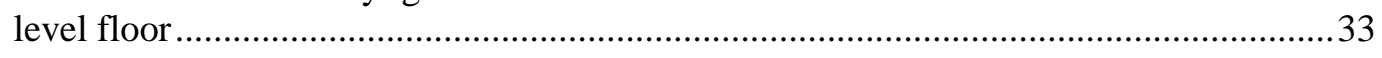

27 Peel-and-stick panel tape provides added assurance that panel seams will remain

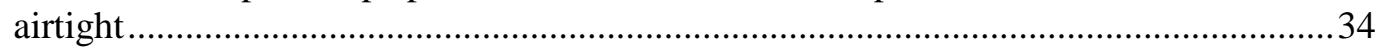

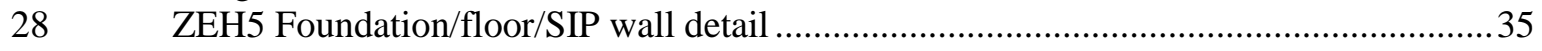

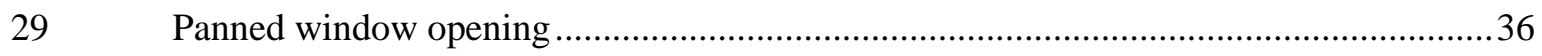

$30 \quad$ Roof drainage plane under the raised metal roof ....................................................36

31 Infrared selective coating was used on the brown raised metal seam roof to cover

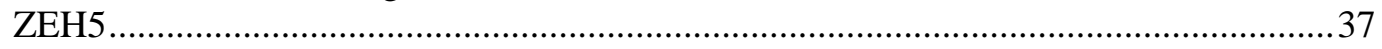

32 S-5 mini clamp holding a solar module on ZEH5 to the raised metal seam ...................38

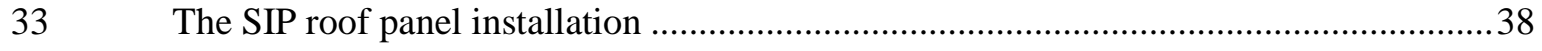

$34 \quad$ Locations and lengths along trenches where ground heat exchanger pipe was

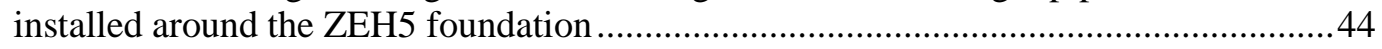

35 Ground loop being installed in the bottom of the sewer pipe trench ..............................45

36 The shaded area marks where the ceiling is dropped to accommodate the HVAC

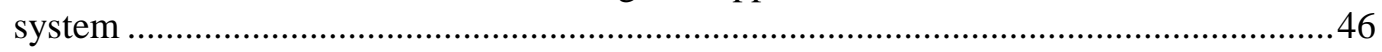

37 Supply ducts located in the conditioned chase formed by the ceiling SIP and dropped ceiling 
Measured air supply cfm delivered to each room in ZEH5 and location of each high sidewall register.

Measured hourly temperatures and relative humidity of the interior space from

November 2008 to October 31, 2009 electric wires from the walkout lower level into the vertical wiring chases in the wall SIP

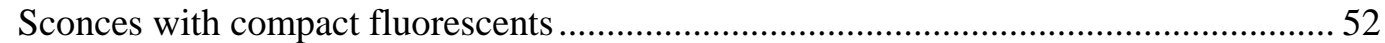

Arrangement TVA requires for tying solar systems to the grid .................................... 52

Method used to tie the PV into the Gridpoint platform that houses the Outback inverter......

Solar modules on the roof of ZEH5 are installed directly to the raised metal seam using the S5 mini clamps without the rails typically run parallel to the raised seams

Solar module cost in the United States and Europe, December 2001 to October 2009 .

Temperatures under the PV modules from 8:00 AM until 7:00 PM on August 1, 2009 .

Sunny Boy (red box at left) installed in TVA-approved Green Power Generation hookup .56

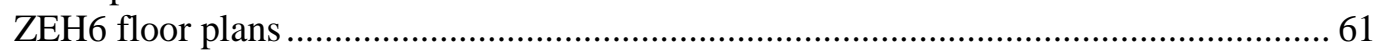

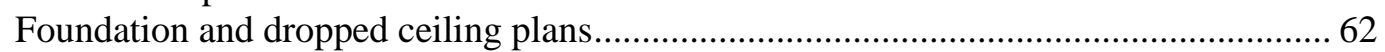

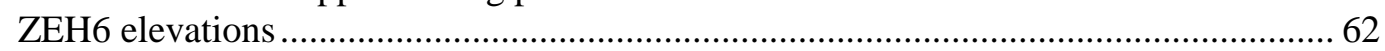

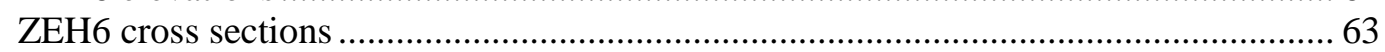

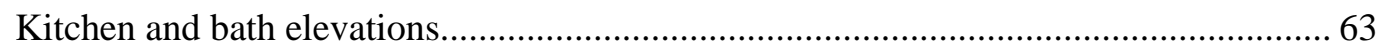

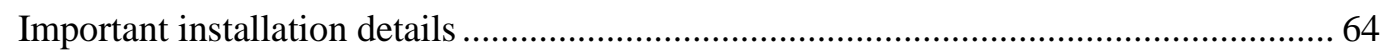

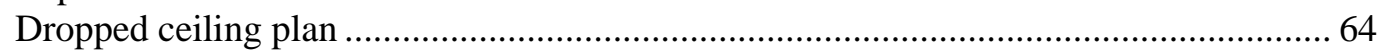

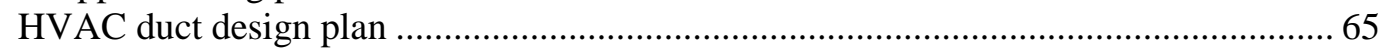

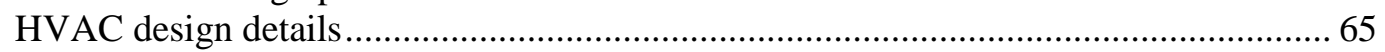

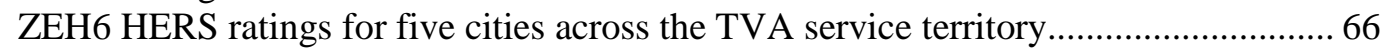

Perspective drawing of ZEH6 by Eason Architects ...................................................... 67

Entering water loop temperature from February 2006-September 2009 ...................... A-2

Geothermal heat pump runtime supply and return average daily air temperature......... A-2

Hourly temperatures and relative humidity upstairs and down in ZEH5 on August 10, 2009

Geothermal heat pump energy needed for the pump, compressor, and fan on

4 days in August 2009

Geothermal heat pump measured monthly kWh for 2007, 2008, and 2009

compared with "best model" (BA prototype model of ZEH5) and with a calibrated model using the actual measured internal loads and an EER of 6.5 instead of the 15.5 used in the best model 


\section{LIST OF TABLES}

Table

Page

1 Envelope technology package in ZEH5 and the Building America benchmark house...... 3 Equipment technology packages in ZEH5 and the Building America benchmark

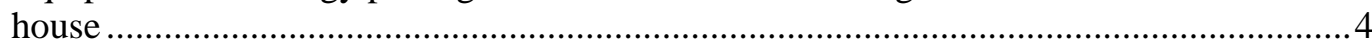

3 Average whole house measured $\mathrm{kWh} / \mathrm{d}$ by data acquisition system for each month ........6

4 ZEH5 two-story measured energy use compared with calibrated model, November 2008-October 2009.

$5 \quad$ ZEH5 two-story and measured energy use and annual cost breakdown, November 2008-October 2009.

$6 \quad$ EnergyGauge results for ZEH5 and Building America benchmark house

7 ZEH5 two-story individual technology energy savings using the Building America

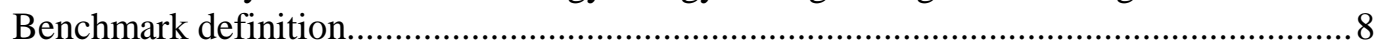

$8 \quad$ Detailed construction costs (estimates) for the ZEH5 two-story test house ....................9

$9 \quad$ Building America cash flow analysis for ZEH5 (Two-story) .......................................11

10 Detailed incremental amortized annual cost using builder cost plus 10\% markup, 30 year mortgage, and $6 \%$ interest......................................................................... 12

11 Increase in calculated heating and cooling loads for ZEH5 when modeled house is

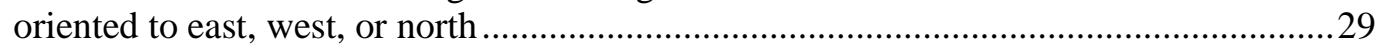

12 Heating and cooling design load breakdowns for ZEH5, calculated using Manual J......43

13 Heating degree days (HDD) and cooling degree days (CDD) for cities across the TVA service territory....

A.1 ZEH5 two-story measured energy use compared with calibrated model, November 2008-October 2009...................................................................................A-1

A.2 ZEH5 two-story and measured energy use and annual cost breakdown, November 2008-October 2009...... 



\section{ABBREVIATIONS, INITIALISMS, AND ACRONYMS}

$\begin{array}{ll}\text { BA } & \text { Building America } \\ \text { CDD } & \text { cooling degree days } \\ \text { cfm } & \text { cubic feet per minute } \\ \text { COP } & \text { coefficient of performance } \\ \text { DAS } & \text { data acquisition system } \\ \text { DOE } & \text { US Department of Energy } \\ \text { ECM } & \text { electronically commuted motor } \\ \text { EER } & \text { energy efficiency ratio } \\ \text { EF } & \text { energy factor } \\ \text { EPS } & \text { expanded polystyrene } \\ \text { HDD } & \text { heating degree days } \\ \text { HDP } & \text { high density polyethylene } \\ \text { HP } & \text { heat pump } \\ \text { HPWH } & \text { heat pump water heater } \\ \text { HSPF } & \text { heating seasonal performance factor } \\ \text { kWp } & \text { peak photovoltaic solar system rating in kilowatts } \\ \text { MEL } & \text { miscellaneous electric loads } \\ \text { ORNL } & \text { Oak Ridge National Laboratory } \\ \text { OSB } & \text { oriented strand board } \\ \text { PV } & \text { photovoltaic } \\ \text { SEER } & \text { seasonal energy efficiency rating } \\ \text { SHGC } & \text { solar heat gain coefficient } \\ \text { SIP } & \text { structural insulated panel } \\ \text { SLA } & \text { specific leakage area } \\ \text { SWH } & \text { solar water heater } \\ \text { TMY } & \text { typical meteorological year } \\ \text { TVA } & \text { Tennessee Valley Authority } \\ \text { XPS } & \text { extruded polystyrene }\end{array}$





\section{ACKNOWLEDGEMENTS}

The author wishes to thank the Tennessee Valley Authority and the US Department of Energy's Building America Program for the resources to conduct this research and prepare this document. The authors are most grateful to the Habitat for Humanity of Loudon County, Tennessee, for opening up the Habitat's Harmony Heights Subdivision and working with us to create a living laboratory that provides invaluable information for builders and homeowners. 



\section{EXECUTIVE SUMMARY}

The US Department of Energy (DOE) Building America (BA) program is an industry-driven research program designed to accelerate the development and adoption of advanced building energy technologies in new and existing homes. This document describes lessons learned from designing, building, and monitoring five affordable, energy-efficient test houses in a single development in the Tennessee Valley Authority (TVA) service area. This work was done through a collaboration of Habitat for Humanity Loudon County, the US Department of Energy (DOE), TVA, and Oak Ridge National Laboratory (ORNL). The houses were designed by a team led by ORNL and were constructed by Habitat volunteers in Lenoir City, Tennessee.

ZEH5, a two-story, four-bedroom, $21 / 2$ bath, $2632 \mathrm{ft}^{2}$ house and the last of the five test houses to be built, was constructed with structural insulated panel walls and roof, a standing-seam roof with infrared reflective coating, an airtight envelope (1.65 air changes per hour at $50 \mathrm{~Pa}$ ), supply mechanical ventilation and ducts inside the conditioned space, an extensive moisture control package, a foundation geothermal space heating and cooling system, a ZEHcor wall (an internal steel-framed utility wall that enables waste heat recovery and optimize usage within the house), a solar water heater, and a $2.5 \mathrm{kWp}$ grid-connected photovoltaic (PV) system. The detailed specifications for the envelope and the equipment used in ZEH5 were compared with the BA Benchmark building, which was created to provide a common baseline for determining energy savings of proposed or existing residential buildings using hourly energy simulations.

ZEH5 had a home energy rating system (HERS) index of 43, which represents more than $50 \%$ less energy than the DOE BA Benchmark building. A high performance, maximum energy efficient house that produces as much energy as it uses would have a HERS rating of 0. Most conventional new houses have HERS ratings around 100, as does the Benchmark building, which is representative of such houses. This house provided an excellent model for conducting research on affordable highperformance houses.

Based on a year's worth of data collected from 94 sensors installed in ZEH5, a computer simulation of house was developed using typical occupancy patterns and energy services for six occupants. Results from the computer simulation indicated that the daily energy costs would be $\$ 1.90 / \mathrm{d}$ based on energy prices at the time of the study (August 2009 residential rates of $\$ 0.10 / \mathrm{kWh}$ and solar buyback at $\$ 0.22 / \mathrm{kWh}$ ). In contrast, costs for the Benchmark building would have been $\$ 5.71 / \mathrm{d}$. The solar fraction for ZEH5 was $25 \%$ or $35 \mathrm{kWh} / \mathrm{d}$; the roof-mounted $2.5 \mathrm{kWp}$ PV system generated $8.7 \mathrm{kWh} / \mathrm{d}$.

ZEH5's impressively low energy bills have generated considerable interest from builders and homeowners who want a similar design adaptable to different climates. Accordingly, the plans for ZEH5 were redesigned without the project constraints to appeal to a more commercial market, and two adaptations were developed: a one-story design (ZEH6) and a two-story design (ZEH7).

The purpose of this report is to educate builders and homeowners about building a similar high performance, maximum energy efficiency house. Detailed drawings, specifications, and lessons learned during construction and from the analysis of data from 94 sensors monitoring electric submetered usage, temperature and relative humidity, hot water usage, and heat pump operation over 1 year are presented. This information should be especially useful to those considering structural insulated panel walls and roof, foundation geothermal technology, space heating and cooling, solar water heaters, and roof-mounted, grid-tied photovoltaic systems.

This report focuses on ZEH6, identical to ZEH5 except that the geothermal system is replaced with a SEER 16 air source unit (like that used in ZEH4). The report also contains plans for the ZEH6 house with projected performance in five major metropolitan areas across the TVA service territory. ZEH6 is much more versatile than the two-story ZEH7 and meets the housing needs of a much larger market. HERS ratings projections for this all-electric house vary from 36 in Memphis, Tennessee, to 46 in Bristol, Tennessee. 



\begin{abstract}
This document describes lessons learned from designing, building, and monitoring five affordable, energy-efficient test houses in a single development in the Tennessee Valley Authority (TVA) service area. This work was done through a collaboration of Habitat for Humanity Loudon County, the US Department of Energy (DOE), TVA, and Oak Ridge National Laboratory (ORNL). The houses were designed by a team led by ORNL and were constructed by Habitat's volunteers in Lenoir City, Tennessee.

ZEH5, a two-story house and the last of the five test houses to be built, provided an excellent model for conducting research on affordable high-performance houses. The impressively low energy bills for this house have generated considerable interest from builders and homeowners around the country who wanted a similar home design that could be adapted to different climates. Because a design developed without the project constraints of ZEH5 would have more appeal for the mass market, plans for two houses were developed from ZEH5: a one-story design (ZEH6) and a two-story design (ZEH7). This report focuses on ZEH6, identical to ZEH5 except that the geothermal heat pump is replaced with a SEER 16 air source unit (like that used in ZEH4). The report also contains plans for the ZEH6 house.

ZEH5 and ZEH6 both use 50\% less energy than the DOE Building America protocol for energyefficient buildings. ZEH5 is a 4 bedroom, $2^{1 / 2}$ bath, $2632 \mathrm{ft}^{2}$ house with a home energy rating system (HERS) index of 43, which qualifies it for federal energy-efficiency incentives (a HERS rating of 0 is a zero-energy house, and a conventional new house would have a HERS rating of 100).

This report is intended to help builders and homeowners build similar high-performance houses. Detailed specifications for the envelope and the equipment used in ZEH5 are compared with the Building America Benchmark building, and detailed drawings, specifications, and lessons learned in the construction and analysis of data gleaned from 94 sensors installed in ZEH5 to monitor electric sub-metered usage, temperature and relative humidity, hot water usage, and heat pump operation for 1 year are presented. This information should be particularly useful to those considering structural insulated panel (SIP) walls and roofing; foundation geothermal heat pumps for space heating and cooling; solar water heaters; and roof-mounted, grid-tied photovoltaic systems. The document includes plans for ZEH6 (adapted from ZEH5), a one-story, high-performance house, as well as projections of how the design might perform in five major metropolitan areas across the TVA service territory. The HERS ratings for this all-electric house vary from 36 (Memphis, Tennessee) to 46 (Bristol, Tennessee).
\end{abstract}





\section{INTRODUCTION}

\subsection{BACKGROUND}

This report provides information for building one- and two-story energy-efficient houses using a commercially available technology package in the mixed-humid climate region. These houses are designed to achieve whole-house energy savings of 50\% less than the US Department of Energy (DOE) Building America (BA) standard for energy efficiency.

Although the information within includes as-built floor plans, cross sections, and elevations for both models (see Sect. 2), the report's final recommendations are for building an affordable one-story house. The plans for the one-story house are based on the same energy technologies used in the twostory, but they also include enhanced architectural features created with the help of focus groups interested in constructing an affordable high performance, maximum energy efficiency house. Technical specifications and detailed costs are provided for the following.

- site development

- building orientation

- envelope components (foundation, above-grade walls, windows, and roof)

- lighting

- appliances

- solar water heaters

- space conditioning systems, including mechanical ventilation, heating, cooling, dehumidification,

- and roof-mounted, grid-tied photovoltaic

Data for the two-story house are provided including construction cost, energy consumption over 1 year, and predicted energy consumption (typical weather year and average United States residential energy use). To predict consumption, data measured from 94 sensors were used to simulate performance with a validated computer model of the house assuming a typical energy use profile for a six-person occupancy over 1 year and a roof-mounted $2.5 \mathrm{kWpeak}$ photovoltaic (PV) solar energy system. This document also contains lessons learned and advice on key construction and commissioning for the house, which should be particularly useful for developing a coordinated set of trade-specific plans, for example, for plumbers, electricians, or roofers.

The lessons learned presented herein come from the experience of designing, building, and monitoring five affordable highly energy-efficient houses through a collaboration of Tennessee Valley Authority (TVA), Habitat for Humanity Loudon County (Habitat), DOE, and Oak Ridge National Laboratory (ORNL). The houses were designed by a team led by ORNL and constructed by Habitat volunteers in Lenoir City, Tennessee.

This report focuses on ZEH5, the fifth in the series of test houses built in the same development, as shown in Fig. 1. ZEH5 is a $2632 \mathrm{ft}^{2}$, two-story design. To meet the Habitat's international guidelines for a single-floor, four-bedroom Habitat for Humanity home, the house was built without steps between the upstairs and downstairs. This house is the largest allowed under

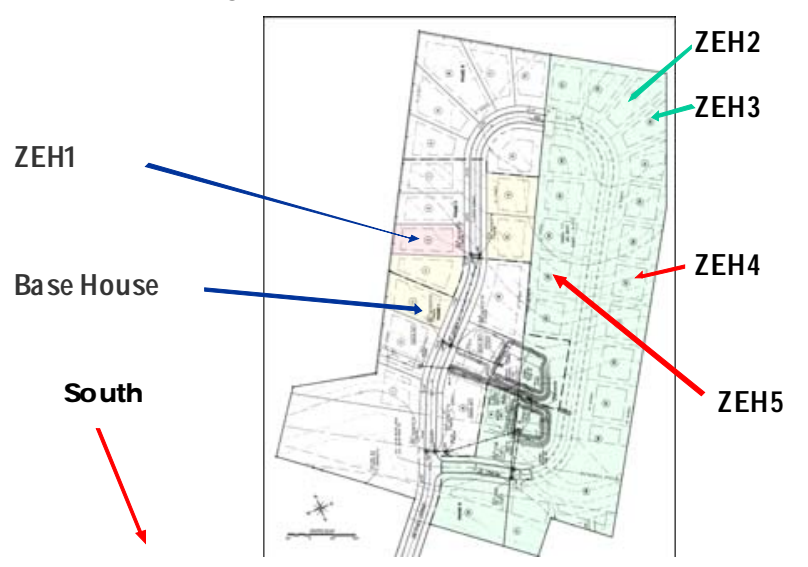

Fig. 1. Layout of Harmony Heights development with five high performance houses. 
Habitat's guidelines. From January 1, 2007, to September 30, 2009, the upstairs and downstairs were heated and cooled continuously. The house was occupied by a family of six from November 1, 2008, until August 31, 2009. The homeowner's son converted the unfinished insulated and conditioned walkout lower level over the summer of 2009 and moved in with his wife and 2 year old daughter on September 1. His material costs for finishing out the living unit downstairs were $\$ 10,000$, which included construction of a full bath, a laundry room, a kitchen, two bedrooms, and dining/living area plus appliances. Flooring is either tile or hardwood, and all walls and ceilings are constructed completely of drywall.

\subsection{THE 50\% ENERGY SAVING SOLUTION}

Together, the construction methods, building products, appliances and equipment used in this allelectric, single-family house, resulted in a very low energy consumption, approaching maximum energy efficiency, meaning that ZEH5 produced almost as much energy as it consumed.)

ZEH5 was instrumented with 94 sensors to record electric sub-metered usage; temperature and relative humidity (ambient, indoor top floor, and lower walkout level); hot water usage; heat pump operation; and other data. Data taken at 15 min intervals were gathered from January 1, 2007, through October 30, 2009. The data were analyzed to determine component performance and energy consumption and to validate computer models. The models predicted that this house, with assumed typical occupancy and $2.5 \mathrm{~kW}$ peak solar PV system, would consume total off-site energy averaging $\$ 1.07 / \mathrm{d}$, including 0.24/d for current hook-up charges, which are fees a utility requires from customers connected to the grid or pipeline even if they do not use a single kilowatt-hour or therm of natural gas. This represents an average residential rate of $\$ 0.10 / \mathrm{kWh}$.

The 2005 total estimated construction cost of $\$ 174,400$ includes the market value of donated materials and estimate of Habitat for Humanity labor. The costs include the rooftop grid-tied $2.5 \mathrm{~kW}$ peak solar PV system, horizontal loop geothermal heat pump (GHP) system, and solar water heater. Federal and electric utility incentives, land cost and development infrastructure, Tennessee sales tax $(\sim 10 \%)$, and the cost of constructing a garage are not included. The cost of materials and value of materials and donated labor were tracked during construction. There is some uncertainty in the cost of labor other than labor associated with plumbing, HVAC, excavation, and foundation. The above-grade envelope can be assembled quickly with a structural insulated panel (SIP) technician and crew with good general carpentry skills. The design's cathedral ceiling meant that the interior framing was a bit more extensive than that of a flat, fixed height ceiling under roof trusses. Section 1.6 details the cost breakdown for ZEH5.

\subsection{TECHNOLOGIES}

Tables 1 and 2 list building envelope and mechanical features used in ZEH5 and compares them with those of the BA Benchmark building (referred to in this report as the benchmark house). This benchmark acts as a reference building for new construction test houses, and has recently been updated to be generally consistent with construction practices from 2010. Details on the other four high performance houses and a baseline Habitat house can be found in a Federal Energy Management Program new technology demonstration publication, "Energy Savings from Small Near-Zero-Energy Houses Integration." (Christian 2007).

The benchmark house HERS Index was 104; the ZEH5 had a HERS Index of 43. Without PV, the HERS Index rose to 54; without the solar water heater, the HERS index rose to 68 (without the PV and solar water heater) (RESNET 2002).

The houses were equipped with two electric utility meters, one to track PV system AC generation and a net meter to show in real time whether the house is using more energy than it is producing, or vice versa. The sum of these two meters, read once a month, represents actual household energy consumption. The net meter allows the surplus energy to flow into the utility grid when a house is 
Table 1. Envelope technology package in ZEH5 and the Building America benchmark house (Note: Both the benchmark house and ZEH5 are two-story, $2632 \mathrm{ft}^{2}$ houses with conditioned volumes of $26,214 \mathrm{ft}^{3}$ )

\begin{tabular}{|c|c|c|}
\hline & Benchmark house & ZEH5 \\
\hline Foundation & $\begin{array}{l}\text { Walkout lower level with same volume as } \\
\text { ZEH5, R-6.5 }\end{array}$ & $\begin{array}{l}\text { Walkout conditioned lower level with no } \\
\text { interior steps to top floor with exterior } \\
\text { insulated block walls (nominal steady state } \\
\text { R-value of R-11) Concrete slab, insulated } \\
\text { underneath with R-10 XPS and exterior } 4 \mathrm{ft} \\
\text { wide apron of R-10 XPS on south side }\end{array}$ \\
\hline Walls & $\begin{array}{l}2 \times 4 \text { frame, ins } \mathrm{R} \text {-value } 13 \text {, framing factor of } \\
0.13 \text {, vinyl siding with solar absorptance of } \\
0.5\end{array}$ & $\begin{array}{l}6.5 \text { in SIP 1\#EPS }(\mathrm{R}-21) \text {, structural splines, } \\
\text { wood I-beams, framing fraction for north } \\
\text { wall }=0.03 \text {, east }=0.06 \text {, south }=0.04, \text { west }= \\
.02 \text {, house wrap, vinyl siding with solar } \\
\text { absorptance of } 0.5\end{array}$ \\
\hline Windows & $\begin{array}{l}231 \mathrm{ft}^{2} \text { window area on south, } 67 \mathrm{ft}^{2} \text { on east } \\
\text { and } 52 \mathrm{ft}^{2} \text { on north, } \mathrm{U} \text {-factor and SHGC of } \\
0.58 \text {, no overhangs }\end{array}$ & $\begin{array}{l}13 \text { windows, } 203 \mathrm{ft}^{2} \text { total window area, } 0.34 \\
\mathrm{U} \text {-factor, } 0.33 \mathrm{SHGC}, \mathrm{VT}=.55 \text {, sill seal pans }\end{array}$ \\
\hline Doors & $\begin{array}{l}2 \text { doors, one solid insulated, one half- view, } \\
\text { both with } U \text {-value of } 0.2 \text {, one } 8 \times 7 \mathrm{ft} \text { garage } \\
\text { door with } U=0.2\end{array}$ & $\begin{array}{l}3 \text { doors, one solid, one half-view insulated, } \\
\text { both with } \mathrm{U} \text {-value of } 0.2 \text { and one full-view } \\
\text { patio door of } 20 \mathrm{ft}^{2} \text { with } 0.33 \mathrm{U} \text {-factor, } \\
0.27 \mathrm{SHGC} \text {, one } 8 \times 7 \mathrm{ft} \text { garage door with } \mathrm{U}= \\
0.2\end{array}$ \\
\hline Roof & Attic floor (R-25.5), framing fraction of 0.13 & $\begin{array}{l}\text { Cathedral ceiling, } 8 \text { in. SIP } 1 \text { \#EPS plus } 2 \text { in. } \\
\text { XPS (R-35), I-joist splines, framing fraction of } \\
0.013\end{array}$ \\
\hline Roofing & $\begin{array}{l}0.75 \text { solar absorptance, composition shingles, } \\
\text { attic ventilation ratio } 1: 300\end{array}$ & $\begin{array}{l}15 \text { in. brown standing } 24 \mathrm{GA} \text { steel seam, } 0.31 \\
\text { reflectivity }\end{array}$ \\
\hline Infiltration & $\mathrm{SLA}=0.00057, \mathrm{ACH}(50)=8.6$ & $\mathrm{SLA}=.00011, \mathrm{ACH}(50)=1.69$ \\
\hline
\end{tabular}

$\mathrm{ACH}=$ air changes per hour, $\mathrm{ECM}=$ electronically commuted motor, $\mathrm{EF}=$ energy factor, $\mathrm{EPS}=$ expanded polystyrene, $\mathrm{HP}=$ heat pump, $\mathrm{HPWH}=$ heat pump water heater, $\mathrm{HSPF}=$ heating seasonal performance factor, OSB = oriented strand board, SEER = seasonal energy efficiency rating, SHGC = solar heat gain coefficient, SIP = structural insulated panel, SLA = specific leakage area, XPS = extruded polystyrene. 
Table 2. Equipment technology packages in ZEH5 and the Building America benchmark house

\begin{tabular}{|c|c|c|}
\hline & Benchmark house & ZEH5 (two-story) \\
\hline Heating and cooling & $\begin{array}{l}\text { Unitary } 3.5 \text { ton } \mathrm{HP}, \text { SEER } 10, \mathrm{SHR}= \\
0.75 \text {, cooling capacity }=27 \mathrm{kBtu} / \mathrm{h}, \\
\text { heating capacity } 44.0 \mathrm{kBtu} / \mathrm{h}, \\
1320 \mathrm{cfm}, \mathrm{HSPF}=6.8\end{array}$ & $\begin{array}{l}2 \text { ton water-loop geothermal, } \\
\text { R-410A, variable speed ECM } \\
\text { indoor fan used a EER } 15.5 \text {, } \\
\text { cooling capacity } 24.7 \mathrm{kBtu} / \mathrm{hr} \text {, } \\
900 \mathrm{cfm} \text {, no superheat recovery, } \\
\mathrm{COP}=3.7 \text {, heating capacity } \\
21.7 \mathrm{kBtu} / \mathrm{h}\end{array}$ \\
\hline Thermostat settings & $76^{\circ} \mathrm{F}$ in summer, $71^{\circ} \mathrm{F}$ in winter & $76^{\circ} \mathrm{F}$ in summer, $71^{\circ} \mathrm{F}$ in winter \\
\hline Mechanical ventilation & None & $\begin{array}{l}\text { Supply to return side of coil, bath } \\
\text { fan exhaust, fixed run time of } \\
33 \% \text {, supply ventilation } \\
\text { rate }=63.7 \mathrm{cfm} \text {, exhaust } \\
\text { ventilation }=36 \mathrm{cfm}\end{array}$ \\
\hline Duct location & $\begin{array}{l}\text { Inside conditioned space, } \mathrm{R}-4 \text {, supply } \\
\text { area } 526 \mathrm{ft}^{2} \text {, return area } 210 \mathrm{ft}^{2} \text {, duct air } \\
\text { leakage }=15 \%\end{array}$ & $\begin{array}{l}\text { Supply and return ducts inside } \\
\text { conditioned space, duct air } \\
\text { leakage }=9.45 \%, \mathrm{R}-5, \text { supply area } \\
394 \mathrm{ft}^{2} \text {, return area } 64.5 \mathrm{ft}^{2},\end{array}$ \\
\hline Air handler location & Interior & Interior \\
\hline Water heater & $\begin{array}{l}\text { Electric, } 50 \text { gal capacity, } E F=0.84 \text {, } \\
\text { usage }=59 \mathrm{gal} / \mathrm{d} \text {, set temp }=120^{\circ} \mathrm{F}\end{array}$ & $\begin{array}{l}\text { Solar water heater, } 80 \mathrm{gal}, \mathrm{EF} \\
=0.91 \text {, set temp }=120 \mathrm{~F}, 40 \mathrm{ft}^{2} \\
\text { collector area, PV pump, } \\
\text { usage }=59 \mathrm{gal} / \mathrm{d}\end{array}$ \\
\hline Lighting & $\begin{array}{l}10 \% \text { fluorescent, } 90 \% \text { incandescent, } \\
2354 \mathrm{kWh} / \mathrm{yr}\end{array}$ & $100 \%$ fluorescent, $753 \mathrm{kWh} / \mathrm{yr}$ \\
\hline Solar PV system & None & $\begin{array}{l}20-110 \mathrm{~W} \text { polycrystalline } \\
2.5 \mathrm{kWp}\end{array}$ \\
\hline
\end{tabular}

$\mathrm{COP}=$ coefficient of performance, $\mathrm{cfm}=$ cubic feet per minute, $\mathrm{ECM}=$ electronically commuted motor, $\mathrm{EER}=$ energy efficiency rating, EF = energy factor; EPS = expanded polystyrene, HP = heat pump, HPWH = heat pump water heater, HSPF = heating seasonal performance factor, OSB = oriented strand board, SEER = seasonal energy efficiency rating, SHGC = solar heat gain coefficient, SIP = structural insulated panel, XPS = extruded polystyrene

using less electricity than the PV system produces, which usually happens on sunny summer afternoons. The power consumed by the household and generated by the PV system is metered separately. Under TVA's Green Power Switch Program, the homeowner is credited $\$ 0.12$ per kWh more than the utility residential rate $(\$ 0.22 \mathrm{kWh}$ at the time of this study) for all the solar power produced.

Supply mechanical ventilation is provided in compliance with American Society of Heating, Refrigerating, and Air-Conditioning Engineers Standard (ASHRAE) 62.2 (ASHRAE 2004). ZEH5 was the first of the five test houses to use a solar water heater. ZEH5 included an extensive moisture management package: a capillary break between the footer and foundation wall, below-grade waterproofed walls covered with insulating drainage board, a footer drain on both sides of the footer, extruded polystyrene (XPS) placed under the walkout lower level slab to minimize condensation by increasing the inside slab surface temperature, airtight construction, balanced mechanical ventilation, insulated ducts inside the conditioned space, panned windows and door openings, transfer grills and jump ducts relieving pressure differences within the house when bedroom doors are shut, windows properly installed with shingle style flashings, roof and wall drainage planes (both above grade and below grade), extended roof overhangs to minimize wind-driven rain envelope penetration, minimum roof membrane penetrations, peel and stick tape on all interior SIP seams, right-sized HVAC (per 
ACCA Manuals J and D, and final grade sloped 5\% at least 6 in. to allow $10 \mathrm{ft}$ from the foundation. Whole house commissioning prior to occupancy included a blower door envelope airtightness test, duct blaster duct tightness test, supply and return cubic feet per minute (cfm) measured and balanced with Manual D design specifications, and a HERS index estimate.

\subsection{ENERGY COST}

\subsubsection{Costs Per Day}

The cost effectiveness of a house like ZEH5 varies with energy rates; climate; energyconsumption habits; utility, state, and federal incentives; and the cost of the selected technologies. The local electricity rate in 2008-2009 test period for ZEH5 was $\$ 0.10$ per $\mathrm{kWh}$, the national average rate in July 2009 was $\$ 0.12$ (EIA 2010). Energy cost savings would be greater in regions with higher electricity and solar buy back rates.

From November 1, 2008-October 30, 2009, with an occupancy of six, ZEH5 had an average daily electricity cost of $\$ 1.58 / \mathrm{d}$ including the solar credit for $3151 \mathrm{kWh}$ at $\$ 0.22 / \mathrm{kWh}$ totaling $\$ 693$ or a credit of $\$ 1.90 / \mathrm{d}$. The benchmark house of the same size and in the same community would be expected to average $\$ 5.71$ per day for electricity. Figure 2 shows the energy consumption and solar generation of ZEH5 (two story) compared with that of the benchmark house; ZEH5 achieves a savings of $\$ 11,307 \mathrm{kWh} / \mathrm{yr}$.

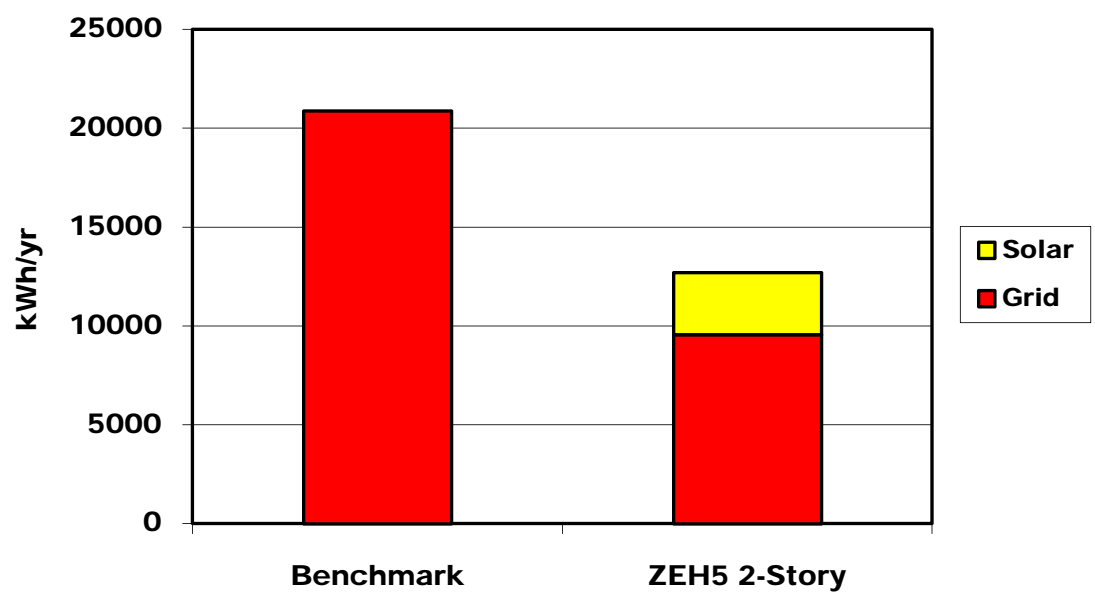

Fig. 2. Annual energy consumption and solar production of ZEH5.

\subsubsection{Measured Data}

Table 3 shows the actual average daily energy consumption data for each month from November 1,2008 -October 31,2009 . The average thermostat settings are very close to $71^{\circ} \mathrm{F}$ for the heating season and $76^{\circ} \mathrm{F}$ for the cooling season. The heat pump coefficient of performance (COP) used for the calibration model was 3.7. The manufacturer's listed COP was 4.4, but the measured water loop pump power is not included, so an additional $16 \%$ increase in total power for the pump is included in the 3.7 value. This results in a very close match of our computer model and actual measurements. For the solar water heating back-up, the manufacturer's suggested energy factor (a measurement of energy-efficiency) was reduced from 0.91 to 0.88 . In addition, the average daily hot water load for the 6-9 people living in this house was found to average 40 gal per day-less than the BA benchmark suggestion of 57 for a 4 bedroom house. These two changes resulted in a very good match of actual measurement with what the model predicted for the backup kilowatt hours needed to 
Table 3. Average whole house measured kWh/d by data acquisition system for each month

\begin{tabular}{lc}
\hline \multicolumn{1}{c}{ Month } & $\begin{array}{c}\text { Measured total energy } \\
(\mathbf{k W h} / \mathbf{d})\end{array}$ \\
\hline November 2008 & 26 \\
December & 33 \\
January 2009 & 38 \\
February & 36 \\
March & 28 \\
April & 23 \\
May & 29 \\
June & 37 \\
July & 36 \\
August & 45 \\
September & 49 \\
October 2009 & 37 \\
Average & 35 \\
\hline
\end{tabular}

provide hot water with a set point of $125^{\circ} \mathrm{F}$. The other loads in the house measured out with about $1000 \mathrm{KWh}$ more than the BA benchmark reference; this was added to the miscellaneous loads in the model, which resulted in a perfect match between model and prediction in the Table 4 "other" column.

As a result of some technical issues with the GHP system, the cooling energy consumed by the GHP was found to be much higher than experienced prior to occupancy on October 28, 2008. A discussion of the GHP and its performance can be found in Appendix A.

Table 4. ZEH5 two-story measured energy use compared with calibrated model, November 2008-October 2009

\begin{tabular}{|c|c|c|c|c|c|c|}
\hline Month & $\begin{array}{l}\text { Space heat } \\
\text { (kWh) }\end{array}$ & $\begin{array}{l}\text { Space } \\
\text { cool } \\
(\mathbf{k W h})\end{array}$ & $\begin{array}{c}\text { Solar water } \\
\text { heater backup } \\
(\mathrm{kWh})\end{array}$ & $\begin{array}{l}\text { Other } \\
(\mathbf{k W h})\end{array}$ & $\begin{array}{c}\text { Total } \\
(\mathbf{k W h})\end{array}$ & $\begin{array}{c}\text { Solar } \\
\text { generation } \\
(\mathbf{k W h})\end{array}$ \\
\hline November 2008 & 176 & & 107 & 458 & 741 & 169 \\
\hline December & 326 & & 151 & 610 & 1087 & 218 \\
\hline January 2009 & 491 & & 158 & 599 & 1248 & 237 \\
\hline February & 334 & & 61 & 704 & 1099 & 299 \\
\hline March & 222 & & 105 & 816 & 943 & 308 \\
\hline April & 144 & & 51 & 525 & 720 & 335 \\
\hline May & & 321 & 36 & 554 & 911 & 316 \\
\hline June & & 642 & 5 & 452 & 1099 & 323 \\
\hline July & & 621 & 2 & 472 & 1095 & 289 \\
\hline August & & 856 & 2 & 501 & 1359 & 298 \\
\hline September & & 652 & 26 & 714 & 1392 & 206 \\
\hline October & & 338 & 87 & 585 & 1010 & 154 \\
\hline Measured & 1693 & 3430 & 791 & 6990 & 12,704 & 3152 \\
\hline $\begin{array}{l}\text { Calibration } \\
\text { model }\end{array}$ & 1688 & 2099 & 786 & 6989 & 11,562 & 3074 \\
\hline $\begin{array}{l}\text { Measured vs. } \\
\text { model }\end{array}$ & $0.3 \%$ & $63 \%$ & $0.6 \%$ & $0 \%$ & $9.9 \%$ & $2.5 \%$ \\
\hline
\end{tabular}


The monthly energy consumption values in Table 5 are based on hard measurements during November 2008-October 2009, when 6 to 9 people were living in this house. The unfinished lower level was occupied full time on Sept. 1, 2009 after being finished out with open living room, dining room and kitchen, laundry room, bathroom, and two bedrooms. The actual energy cost for an entire year to the homeowners was $\$ 1.58 / \mathrm{d}$. If the cooling performance of the geothermal system was 15.5 as expected, this daily cost would have been $\$ 1.25 / \mathrm{d}$.

Table 5. ZEH5 two-story and measured energy use and annual cost breakdown, November 2008-October 2009

\begin{tabular}{lccccccc}
\hline Month & $\begin{array}{c}\text { Space } \\
\text { heat } \\
(\mathbf{k W h})\end{array}$ & $\begin{array}{c}\text { Space } \\
\mathbf{c o o l} \\
\mathbf{( k W h )}\end{array}$ & $\begin{array}{c}\text { Solar water } \\
\text { heater backup } \\
(\mathbf{k W h})\end{array}$ & $\begin{array}{c}\text { Other } \\
(\mathbf{k W h})\end{array}$ & $\begin{array}{c}\text { Total } \\
(\mathbf{k W h})\end{array}$ & $\begin{array}{c}\text { Solar } \\
\text { generation } \\
(\mathbf{k W h})\end{array}$ & \$/d \\
\hline Measured & 1693 & 3430 & 791 & 6990 & 12,704 & 3152 & \\
Annual cost $^{a}$ & $\$ 169$ & $\$ 343$ & $\$ 79$ & $\$ 699$ & $\$ 1270$ & $-\$ 693$ & $\$ 1.58$ \\
\hline
\end{tabular}

${ }^{a}$ Residential rate $\$ 0.10 / \mathrm{kWh}$, solar buyback of $\$ 0.22$.

\subsection{ENERGY SAVINGS-ZEH5 VS. BUILDING AMERICA BENCHMARK}

Using the EnergyGauge program (FSEC 2006), we constructed a benchmark model following the Building America Research Benchmark Definition (NREL 2008) to compare with the two-story ZEH5. ZEH5 required 68\% less energy than the benchmark house. Without the solar PV system, the reduction in energy savings decreases to 53\%. ZEH5 has a HERS index of 43, which qualifies for the $\$ 2000$ federal tax credit for the builder. The benchmark house has a HERS index of 104. Table 6 shows where the improvements in the home were made to lower energy usage. The space heating, space cooling, lighting and domestic hot water loads had about $70 \%$ reductions. The only other energy savings assumed is from the Energy Star refrigerator. The hard measured energy consumption of the fridge was $447 \mathrm{kWh}$ during the occupied test period from November 1, 2008 until October 31, 2009. The plug loads and all the remaining appliance energy usages are assumed to be the same in ZEH5 and the benchmark house, as called for in the BA energy savings methodology. The remaining appliance and plug loads represent $50 \%$ of the total energy consumption of this all-electric house and after subtracting the onsite PV generation, $71 \%$ of the energy needed from off site.

Tables 1 and 2 showed the envelope and equipment features used to generate the computer model comparison of ZEH5 and the benchmark house. Table 7 shows the energy and dollar savings from

Table 6. EnergyGauge results for ZEH5 and Building America benchmark house

\begin{tabular}{lccc}
\hline \multirow{2}{*}{ End use } & \multicolumn{2}{c}{$\begin{array}{c}\text { Annual site energy } \\
(\mathbf{k W h})\end{array}$} & \multirow{2}{*}{ \% Savings } \\
\cline { 2 - 3 } & Two-story benchmark & ZEH5 & \\
\hline Space heating & 6297 & 1703 & $73 \%$ \\
Space cooling & 3640 & 938 & $74 \%$ \\
Domestic hot water & 3325 & 1142 & $66 \%$ \\
Lighting & 2354 & 753 & $68 \%$ \\
Refrigerator & 669 & 475 & $29 \%$ \\
Appliances + plug & 4787 & 4788 & $0 \%$ \\
Total usage & 21,072 & 9799 & $53 \%$ \\
\hline Site generation & 0 & 3074 & \\
\hline Net energy use & 21,072 & 6725 & $68 \%$ \\
\hline
\end{tabular}


Table 7. ZEH5 two-story individual technology energy savings using the Building America Benchmark definition

\begin{tabular}{|c|c|c|c|c|c|c|c|c|c|c|}
\hline & \multirow{2}{*}{$\begin{array}{l}\text { Technologies in } \\
\text { incremental stages }\end{array}$} & \multirow{2}{*}{$\begin{array}{c}\text { Site } \\
\text { energy } \\
(\mathbf{k W h})\end{array}$} & \multirow{2}{*}{$\begin{array}{l}\text { Est. } \\
\text { source } \\
\text { energy } \\
\text { (MBtu) }\end{array}$} & \multirow{2}{*}{$\begin{array}{l}\text { Savings } \\
(\%)\end{array}$} & \multicolumn{2}{|c|}{$\begin{array}{c}\text { National average } \\
\text { energy cost }^{a}\end{array}$} & \multicolumn{3}{|c|}{$\begin{array}{c}\text { Builder standard } \\
{\text { (local costs })^{b}}^{\text {B. }} \\
\end{array}$} & \multirow{2}{*}{$\begin{array}{c}\text { Package } \\
(\$ / y r)\end{array}$} \\
\hline & & & & & $(\$ / y r)$ & $\begin{array}{l}\text { Savings } \\
(\%)\end{array}$ & $\begin{array}{c}\text { Energy } \\
\text { cost } \\
(\$ / y r) \\
\end{array}$ & $\begin{array}{l}\text { Savings } \\
(\%)\end{array}$ & $\begin{array}{c}\text { Measure } \\
\text { value } \\
(\$ / y r)\end{array}$ & \\
\hline (a) & BA Benchmark & 20,860 & 225 & & 2,503 & & 2,086 & & & \\
\hline (b) & $\begin{array}{l}\mathbf{a}+\text { improved roof } \\
\text { R-value and reflectivity }\end{array}$ & 20,495 & 221 & 2 & 2,459 & 2 & 2,050 & 2 & 37 & \\
\hline (c) & $\begin{array}{l}\mathbf{b}+\text { thermal mass } \\
\text { (concrete slab and } \\
\text { lower level block } \\
\text { walls) }\end{array}$ & 19,450 & 210 & 7 & 2,334 & 7 & 1,945 & 7 & 105 & 141 \\
\hline (d) & $\mathbf{c}+$ foundation R-value & 18,933 & 204 & 9 & 2,272 & 9 & 1,893 & 9 & 52 & 193 \\
\hline (e) & $\begin{array}{l}\mathbf{d}+\text { improved wall } \\
\text { R-value }\end{array}$ & 18,546 & 200 & 11 & 2,226 & 11 & 1,855 & 11 & 39 & 231 \\
\hline (f) & $\begin{array}{l}\mathbf{e}+\text { high performance } \\
\text { windows and smaller } \\
\text { window area }\end{array}$ & 17,782 & 192 & 15 & 2,134 & 15 & 1,778 & 15 & 76 & 308 \\
\hline (g) & $\mathbf{f}+$ lighting & 16,035 & 173 & 23 & 1,924 & 23 & 1,604 & 23 & 175 & 483 \\
\hline (h) & $\begin{array}{l}\mathbf{g}+\text { Energy Star } \\
\text { refrigerator } \\
\mathbf{h}+\text { tighter envelope, } \\
\text { mechanical ventilation } \\
\text { and smaller ducts }\end{array}$ & 15,863 & 171 & 24 & 1,904 & 24 & 1,586 & 24 & 17 & 500 \\
\hline (j) & $\mathbf{i}+$ geothermal & 11,790 & 127 & 43 & 1,415 & 43 & 1,179 & 43 & 225 & 907 \\
\hline $\begin{array}{l}\text { (k) } \\
\text { (l) }\end{array}$ & $\begin{array}{l}\mathbf{j}+\text { solar water heater } \\
\text { photovoltaic site }\end{array}$ & 9,603 & 104 & 54 & 1,152 & 54 & 960 & 54 & 219 & 1,126 \\
\hline (m) & $\begin{array}{l}\text { generation } \\
\mathbf{k}+\mathbf{l}\end{array}$ & $\begin{array}{l}3,153 \\
6,672\end{array}$ & 72 & 68 & 396 & 84 & 267 & $87 \%$ & 694 & 1,819 \\
\hline
\end{tabular}


individual components of ZEH5. The entire package of features saves $\$ 1819$ per year with the PV generation and the $\$ 0.22 /$ solar kWh buyback. For this house to attain a DOE Building America defined 50\% savings, all but the solar PV features are needed. This includes the geothermal heat pump and the solar water heater.

\subsection{FIRST COST}

\subsubsection{Total Construction Cost}

Table 8 shows the cost break down for constructing ZEH5 in 2005. Phase codes indicate actual costs that are supported by invoices obtained from Habitat records. The approximate market value of volunteer labor and donated materials are also shown in Table 8. The estimate of the actual cost to construct this house, including finishing the lower level $(\$ 14,755)$, is $\$ 174,406$. It is interesting to note that the current homeowner converted the lower level to a second living unit for a total material cost of $\$ 10,000$, which included all appliances, which were estimated at $\$ 2,000$. Since Habitat is a nonprofit, there was no sales tax on the cost of construction materials. To approximate a realistic market cost for this house, a 10\% sales tax (actual Tennessee sales tax) and a 20\% overhead and profit margin were added to the estimated total cost of construction. This results in an overall estimated cost of $\$ 226,728$, which is representative of a market sale price for this house (and includes $\$ 22,200$ for the lot) and a per-square-foot cost of $\$ 86$ - a reasonable estimate with very low-cost finish out details (kitchen and bath cabinets, flooring, etc.).

Table 8. Detailed construction costs (estimates) for the ZEH5 two-story test house

\begin{tabular}{|c|c|c|}
\hline $\begin{array}{l}\text { Phase } \\
\text { code }\end{array}$ & Phase description & Cost $(\$)$ \\
\hline 1 & Site preparation & $4,841.01$ \\
\hline 3 & Foundation & $13,794.88$ \\
\hline 4 & Termite pre-treatment & 200 \\
\hline 5 & Framing and decking & 8226.27 \\
\hline 6 & Trusses & - \\
\hline 7 & Roofing materials & 133.06 \\
\hline 8 & Roofing labor & - \\
\hline 9 & Guttering & 325 \\
\hline 10 & Windows & 250 \\
\hline 11 & Bathtub and water heater & 720.68 \\
\hline 12 & Exterior doors & 830.5 \\
\hline 13 & Siding and scaffolding & $1,794.04$ \\
\hline 14 & Plumbing materials & $2,740.39$ \\
\hline 15 & Plumbing labor & $2,606.25$ \\
\hline 16 & Toilets & 526.47 \\
\hline 17 & HVAC (not total cost-see below) & 450 \\
\hline 18 & Insulation & - \\
\hline 19 & Sheetrock materials & 1676.17 \\
\hline 20 & Sheetrock labor & $1,871.03$ \\
\hline 21 & Interior doors & 926.69 \\
\hline 22 & Paint & 286.59 \\
\hline 23 & Trim molding and casing & - \\
\hline 24 & Cabinets & $2,327.03$ \\
\hline 26 & Closet Maid & - \\
\hline 27 & Flooring & $1,600.00$ \\
\hline 29 & Electrical materials \& fixtures & $2,629.39$ \\
\hline
\end{tabular}


Table 8. (continued)

\begin{tabular}{|c|c|c|}
\hline $\begin{array}{c}\text { Phase } \\
\text { code }\end{array}$ & Phase description & Cost $(\$)$ \\
\hline 30 & Electrical labor & - \\
\hline 31 & Landscaping & 1741.78 \\
\hline 32 & Driveway & 4143.52 \\
\hline 33 & Final grade & 2665.16 \\
\hline 37 & Storage building & 900 \\
\hline 39 & Land \& infrastructure costs & $16,911.70$ \\
\hline 40 & Miscellaneous & 300.28 \\
\hline & Extra excavation for geothermal loop and labor to install & \\
\hline 50 & walkout lower level floor insulation & $3,215.16$ \\
\hline \multirow[t]{4}{*}{55} & Closing costs & 100 \\
\hline & Overhead & $5,000.00$ \\
\hline & Total construction expenditures & $83,733.05$ \\
\hline & Private-sector donations & \\
\hline 3 & Foundation labor & 467 \\
\hline 9 & Gutter installation & 136 \\
\hline 10 & Windowsills & - \\
\hline 27 & Flooring & 200 \\
\hline 39 & Land \& infrastructure costs & $4,000.00$ \\
\hline \multirow[t]{6}{*}{45} & Miscellaneous: & - \\
\hline & Labor & $6,000.00$ \\
\hline & Campbell \& Associates & - \\
\hline & Southeastern Title & 345 \\
\hline & Total private-sector donations & $11,148.00$ \\
\hline & Total-construction and private donations & $94,881.05$ \\
\hline \multicolumn{3}{|c|}{ ORNL donations } \\
\hline & SIP & 17,000 \\
\hline & Andersen Windows & 3,830 \\
\hline & Andersen patio door & 1,000 \\
\hline & Englert roof (2006 costs) & 6,950 \\
\hline & Solar water heater & 2,400 \\
\hline & Solar water heater installation & 800 \\
\hline & DuPont Tyvek and window install & 1,200 \\
\hline & HVAC (City Heat and Air), labor & 1,500 \\
\hline & WaterFurnace equipment and piping & 4,000 \\
\hline & Coil install & 1,500 \\
\hline & AirCycler & 150 \\
\hline & Tremco foundation system & 7,000 \\
\hline & Gordon Myers, donated time and equipment & 1,300 \\
\hline & Dow XPS & 1,100 \\
\hline & Pipe insulation & 40 \\
\hline & Solar PV system & 15,000 \\
\hline & Total ORNL donations & 64,770 \\
\hline \multicolumn{3}{|c|}{ Walkout lower level finishing } \\
\hline & Interior wall framing & 2,400 \\
\hline & Drywall & 2,000 \\
\hline & Steps to upstairs & 3,000 \\
\hline & HVAC ducts & 655 \\
\hline & Flooring materials & 1,600 \\
\hline & Flooring labor & 1,000 \\
\hline & Bathtub & 300 \\
\hline & More plumbing & 800 \\
\hline & Interior doors & 500 \\
\hline
\end{tabular}


Table 8. (continued)

\begin{tabular}{|c|c|c|}
\hline $\begin{array}{l}\text { Phase } \\
\text { code }\end{array}$ & Phase description & Cost $(\$)$ \\
\hline & More electrical wiring & 1,300 \\
\hline & Bathroom cabinets & 1,200 \\
\hline & Total, walkout lower level finishing & 14,755 \\
\hline \multicolumn{2}{|c|}{ Total costs-construction and donations } & $\begin{array}{l}\$ 174,406.05 \\
\$ 226,727.87\end{array}$ \\
\hline \multicolumn{2}{|c|}{ Total with $10 \%$ sales tax and $20 \%$ builder markup } & $\$ 85.88$ \\
\hline
\end{tabular}

\subsubsection{Neutral Cash Flow Analysis}

ZEH5 meets neutral cash flow criteria without solar PV and without incentives. Table 9 shows a positive cash flow of $\$ 6.25$ per year (annual energy savings_-amortized cost). With all the available incentives (excluding PV incentives), the positive cash flow rises to \$324 per year. Including PV and PV incentives keeps a positive cash flow of $\$ 160$. EnergyGauge modeling for a typical weather year in Knoxville projects that ZEH5 would need to purchase $6672 \mathrm{kWh}$ from the electric grid. The nextto-last row in Table 9 shows that for an incremental cost of $\$ 178$, renewable grid power can be purchased from TVA under the Green Power Switch Program. For \$18/yr negative cash flow, a house like ZEH5 (two-story) in the Knoxville, Tennessee, climate could be powered entirely by renewable energy.

Table 9. Building America cash flow analysis for ZEH5 (Two-story)

\begin{tabular}{lcc}
\hline & $\$$ & $\$ /$ year \\
\hline Added annual mortgage cost w/o site gen., w/o incentives & & $(\$ 1,119)$ \\
Annual energy savings w/o site generation & & $\$ 1125.70$ \\
Net cash flow to consumer w/o site gen. & & $\$ 6.25$ \\
Added annual mortgage cost w/o site gen., with incentives & & \\
$\quad(2,3$, and 5 listed under REBATES/INCENTIVES below) & & $\$ 324$ \\
Net cash flow to consumer w/o site gen. with incentives & & \\
$\quad$ (2,3, and 5 listed under REBATES/INCENTIVES below) & & $(\$ 2,584)$ \\
Added annual mortgage cost with site gen., w/o PV incentives & & \\
Net cash flow to consumer with site gen., w/o PV incentives & & \\
REBATES/INCENTIVES & & $\$ 764)$ \\
1. TVA Generation Partner & -1000 & $\$ 83$ \\
2. Federal 30\% geothermal tax credit & -2477 & $\$ 160$ \\
3. IRS 50\% saver & -2000 & $\$ 439$ \\
4. Federal 30\% Solar PV & -6105 & $\$ 91$ \\
5. Federal Solar water heater & -1263 & $\$ 924$ \\
Total incentives & $-12,845$ & $(\$ 1,659)$ \\
Incremental mortgage cost w PV & 23,065 & $\$ 160$ \\
Net cash flow to consumer with site gen. with incentives & & $(\$ 178)$ \\
Annual cost to by renewable grid power from TVA & & $(\$ 18)$ \\
Net annual cash flow to use 100\% renewable energy & & \\
\hline
\end{tabular}

Table 10 shows the detailed spread sheet used to estimate the incremental amortized annual cost difference between standard builder practices, which in this case is assumed to be the benchmark house and ZEH5. 
Table 10. Detailed incremental amortized annual cost using builder cost plus $10 \%$ markup, 30 year mortgage, and $6 \%$ interest

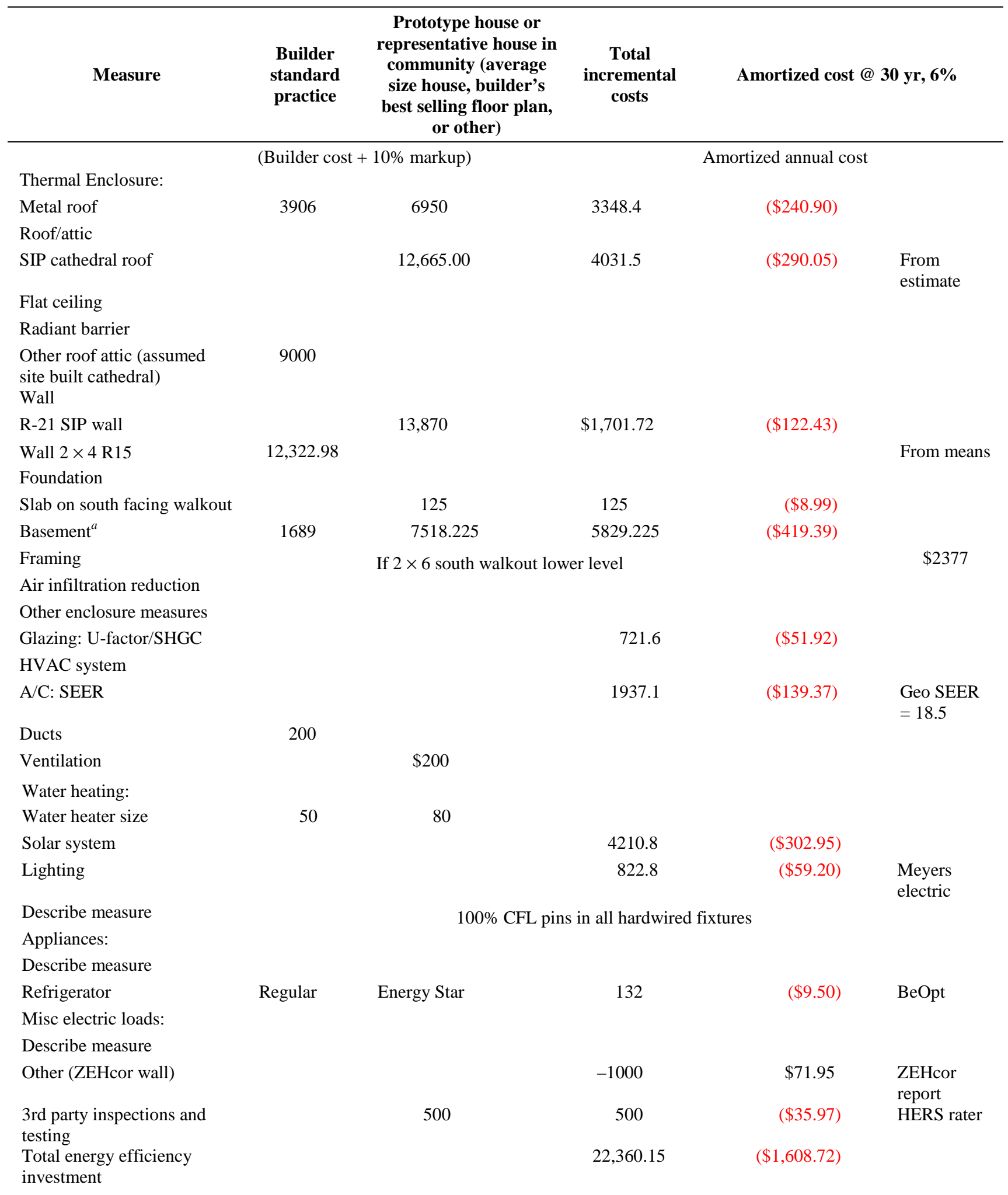


Table 10. (continued)

\begin{tabular}{|c|c|c|c|c|c|}
\hline \multirow[t]{2}{*}{ Measure } & \multirow[t]{2}{*}{$\begin{array}{l}\text { Builder } \\
\text { standard } \\
\text { practice }\end{array}$} & \multirow{2}{*}{$\begin{array}{c}\text { Prototype house or } \\
\text { representative house in } \\
\text { community (average } \\
\text { size house, builder's } \\
\text { best selling floor plan, } \\
\text { or other) }\end{array}$} & \multirow{2}{*}{$\begin{array}{c}\begin{array}{c}\text { Total } \\
\text { incremental } \\
\text { costs }\end{array} \\
\text { First cost }\end{array}$} & \multicolumn{2}{|c|}{ Amortized cost @ 30yr, 6\% } \\
\hline & & & & $\begin{array}{c}\text { Amortized cost @ } \\
30 \mathrm{yr}, 6 \%\end{array}$ & $\begin{array}{l}\text { Simple } \\
\text { payback }\end{array}$ \\
\hline Energy cost savings without PV & & $\$ 1,125.70$ & & & \\
\hline $\begin{array}{l}\text { Cash flow without the solar but } \\
\text { including the metal roof and } \\
\text { insulated masonry foundation }\end{array}$ & & $(\$ 483.02)$ & & & 20 \\
\hline $\begin{array}{l}\text { Remove incremental cost of the } \\
\text { metal roof }\end{array}$ & & & $-3,348.40$ & $\$ 240.90$ & \\
\hline $\begin{array}{l}\text { Change walkout south foundation } \\
\text { wall to } 2 \times 6^{a}\end{array}$ & & & $-3,452.23$ & $\$ 248.37$ & \\
\hline $\begin{array}{l}\text { Without solar PV, metal roof, and } \\
2 \times 6 \text { south foundation wall }\end{array}$ & & $\$ 6.25$ & $15,559.52$ & $(\$ 1,119.45)$ & 14 \\
\hline With incentives added & & $\$ 323.56$ & $9,820.02$ & $(\$ 706.51)$ & 9 \\
\hline \multicolumn{6}{|l|}{ With PV solar electric } \\
\hline $\begin{array}{l}\text { Sharp PV solar electric system } \\
\text { (including install) }\end{array}$ & & & 20,350 & $(\$ 1,464.10)$ & \\
\hline Total with PV, no incentives & & & $35,909.52$ & $(\$ 2,583.55)$ & 20 \\
\hline \multicolumn{6}{|l|}{ REBATES/INCENTIVES } \\
\hline TVA Generation Partner & & & -1000 & $\$ 71.95$ & \\
\hline $\begin{array}{l}\text { Federal } 30 \% \text { geothermal, from cost } \\
\text { table sum }=\$ 8255\end{array}$ & & & -2476.5 & $\$ 82.55$ & \\
\hline IRS 50\% saver & & & -2000 & $\$ 143.89$ & \\
\hline Federal solar water heater & & & -1263 & $\$ 90.87$ & \\
\hline Federal solar PV; $30 \%$ & & & -6105 & $\$ 439.23$ & \\
\hline Total incentives & & & $-12,844.50$ & $\$ 924.11$ & \\
\hline Incremental cost after incentives & & & $23,065.02$ & $(\$ 1,659.44)$ & 13 \\
\hline $\begin{array}{l}\text { Net present value of an energy } \\
\text { savings of } \$ 1819.36\end{array}$ & & $\$ 1,819.36$ & $(\$ 25,288)$ & & \\
\hline Cash flow with existing incentives ${ }^{b}$ & & $\$ 159.92$ & & & \\
\hline $\begin{array}{l}\text { Additional cost to buy green power } \\
\text { for the prototype }\end{array}$ & & & $(\$ 177.92)$ & & \\
\hline $\begin{array}{l}\text { Cost to get to } 100 \% \text { renewable } \\
\text { power }\end{array}$ & & & $(\$ 18.00)$ & & \\
\hline
\end{tabular}

${ }^{a}$ If using $2 \times 6$ south walkout lower level instead of concrete block with exterior insulation and horizon finishing system the cost for the prototype would be only $\$ 2377$.

${ }^{b}$ Increasing the interest rate from $6 \%$ to $7 \%$ makes the cash flow negative on this case.

Table 10 shows the detailed spread sheet used to estimate the incremental amortized annual cost difference between standard builder practices, which in this case is assumed to be the benchmark house and ZEH5.

The neutral cash flow analysis is based on the assumption that the relatively expensive south façade of the lower level with its exterior insulated finish would be replaced with an airtight $2 \times 6$ optimum value frame system. A second assumption is that the added expense of the metal roof, which 
has a longer service life, is not only a convenient method of attaching solar modules to the roof, but also enhances durability; therefore, the metal roof expense is not included in the incremental cost for ZEH5's higher energy performance.

Options for enhancing neutral cash flow criteria are:

1. Increase the utility solar buy back rate for houses like ZEH5 that have a HERS index of less than 70 from $\$ 0.22 / \mathrm{kWh}$ to $\$ 0.40 / \mathrm{kWh}$. This would bring the daily cost for all the energy needs of ZEH5 from $\$ 1.58$ to zero.

2. Reduce the Tennessee state sales tax on the solar equipment, which includes the PV and solar water heater totaling $\$ 24,561$. The current rate is $7 \%$. This would result in a first cost savings of $\$ 1719$ or an amortized cost of $\$ 124 /$ year.

3. Organize a utility-scale mass purchase of key energy efficiency or solar equipment; for example, a mass purchase could help reduce installed cost of PV.

4. Because the house is equipped with extensive energy saving technologies, solar on the roof, and continuous feedback of how incredibly low the energy bills are compared with others, it could be assumed that this would lead to occupants being very mindful of energy efficient practices in the house. An increase in the availability of similar homes could result in reduced plug loads from the typical average U.S. household. 


\section{FLOOR PLANS, CROSS SECTIONS, AND ELEVATIONS}

\subsection{ZEH5 DESCRIPTION}

ZEH5 is a $2632 \mathrm{ft}^{2}$ two story dwelling with a walkout lower level (Fig. 3). The floor plan (shown in Sect. 2.2) has four bedrooms, a combination living-dining room, a kitchen, a laundry room, and two bathrooms. The walls and roof are made of 6.5 in. and 8 in. SIP, respectively (Fig. 4).

The SIPs used on ZEH5 and shown in Fig. 4 are made of expanded polystyrene insulation (EPS) sandwiched between two 7/16 in. sheets of oriented strand board (OSB). Before the metal roofing was installed, 2 in. of XPS was added on top of the 8 in. thick SIP roof. As shown in Fig. 5, XPS is framed with $2 \times 4 \mathrm{~s}$ along the gable and eave edges of the roof.

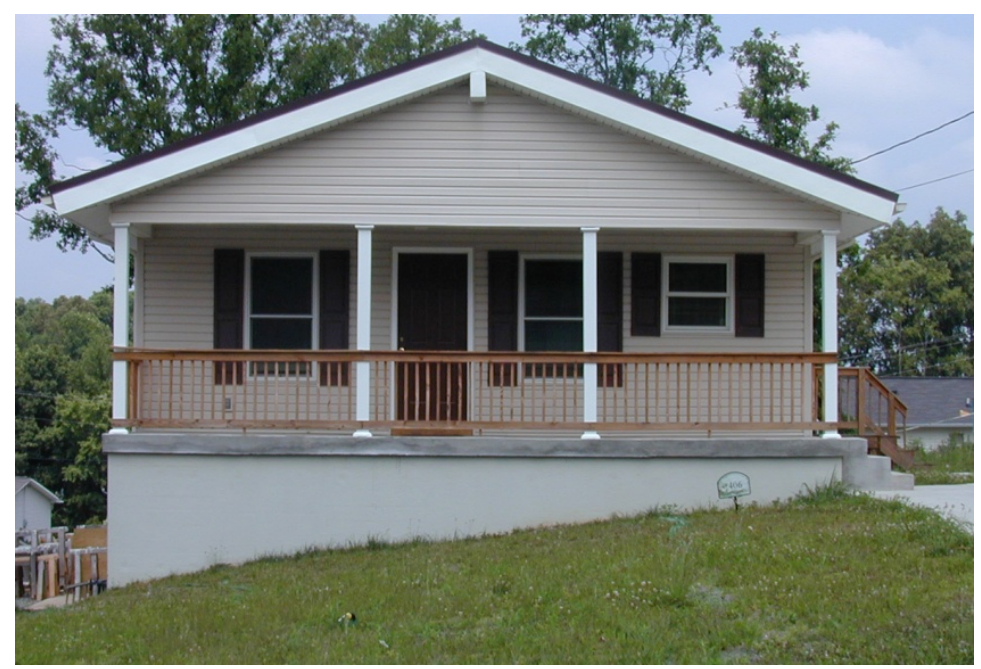

Fig. 3. East elevation of ZEH5 from the street.

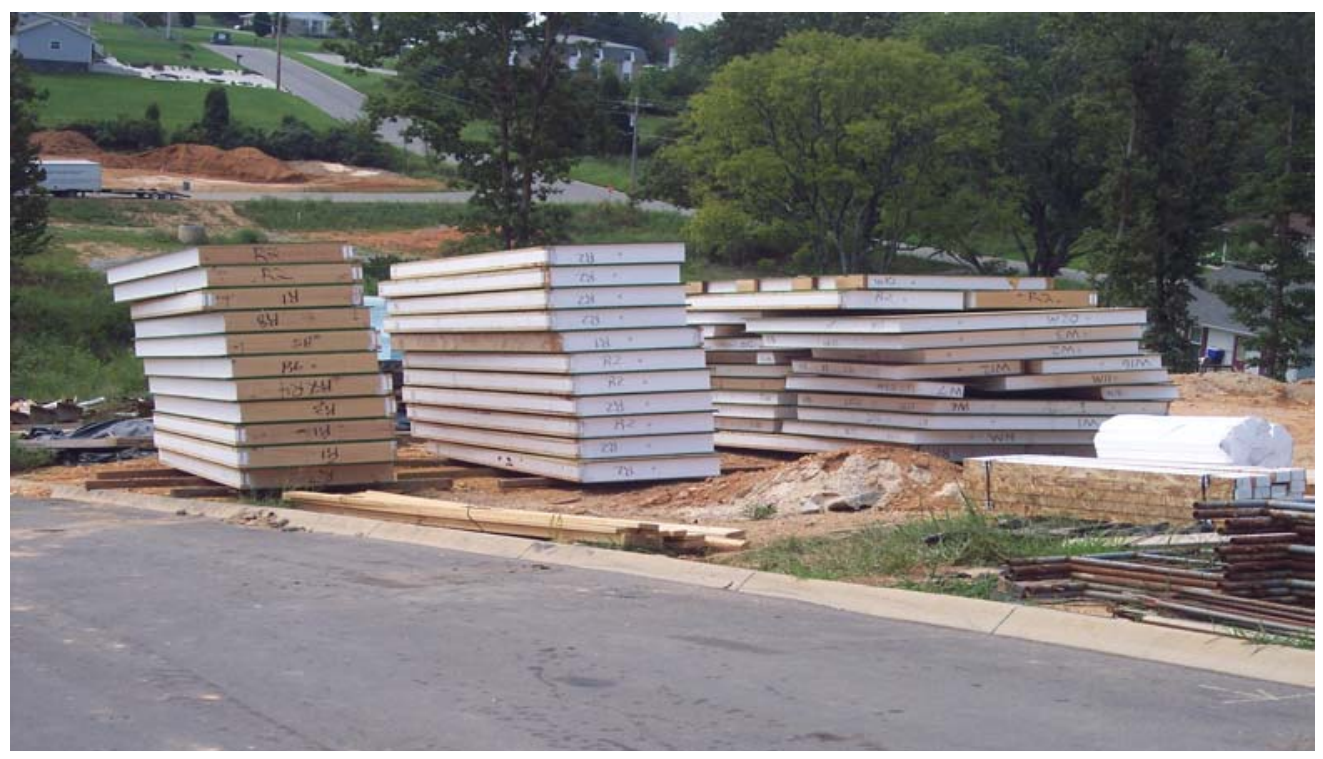

Fig. 4. Structural insulated panels (SIPs) for ZEH5 come numbered to match the panel cut drawings. SIP should be stacked in the order in which they will be installed. 


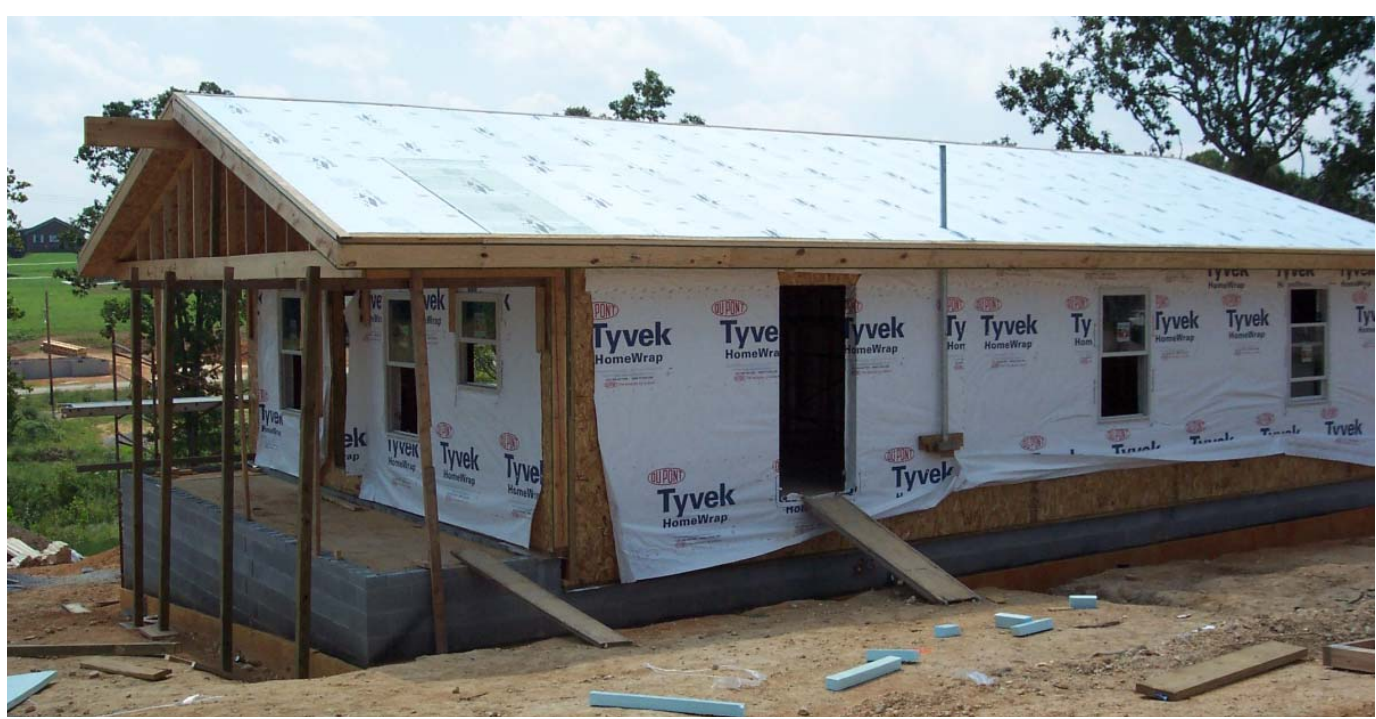

Fig. 5. Before the metal roofing is installed, 2 in. of XPS is laid directly on top of the 8 in. thick SIP roof panels.

A blower-door test of ZEH5 measured 1.65 air changes per hour $(\mathrm{ACH})$ at $50 \mathrm{~Pa}$. The HVAC unit is a 2 ton geothermal horizontal water-loop with a variable-speed indoor circulating fan. The geothermal ground loop was installed without having to do additional excavation beyond what was needed to construct the foundation and connect the buried utilities.

Hot water for ZEH5 is provided by a solar water heater with electric resistance backup. Figure 6 shows the solar water heater collectors and the $11 \mathrm{~W}$ PV panel that powers a $12 \mathrm{~V} \mathrm{DC}$ pump. The two solar collectors have a total net area of $37 \mathrm{ft}^{2}$. The roof is an infrared reflective brown 24 gauge standing-seam steel roof with a 4/12

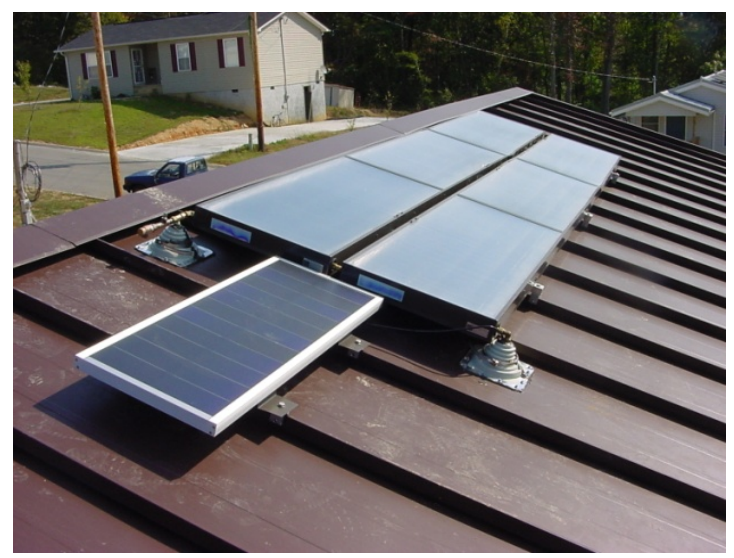

Fig. 6. Solar water heater collectors and the $11 \mathrm{~W}$ PV panel to power a $12 \mathrm{~V}$ DC pump. pitch. The $2.5 \mathrm{~kW}$ PV system consists of $12208 \mathrm{~W}$ solar modules connected to an Outback inverter.

\subsection{FLOOR PLAN}

The floor plan for ZEH5 as built is shown in Fig. 7. The kitchen, main bathroom, and laundry room are connected to the 12 in. thick ZEHcor (utility) wall and thus are fixed. However, the remainder of the layout is extremely flexible because none of the interior walls are structural. This allows multiple options with 1, 2, or 3 bedrooms. Placing the master bedroom where bedrooms 2 and 3 are located and opening up the rest of the plan along with the cathedral ceiling makes this small house feel spacious. The walkout lower level is shown in Fig. 8 with the overall dimensions. The homeowner completely finished out this floor with two bedrooms on the south side and an open living, dining, and kitchen area on the west side of the plan. The garage door was removed and two $30 \times 50$ double-hung low emissivity (low E) double-pane windows installed in a $2 \times 6$ wood frame wall filling the $8 \mathrm{ft} \times 7 \mathrm{ft}$ opening. 


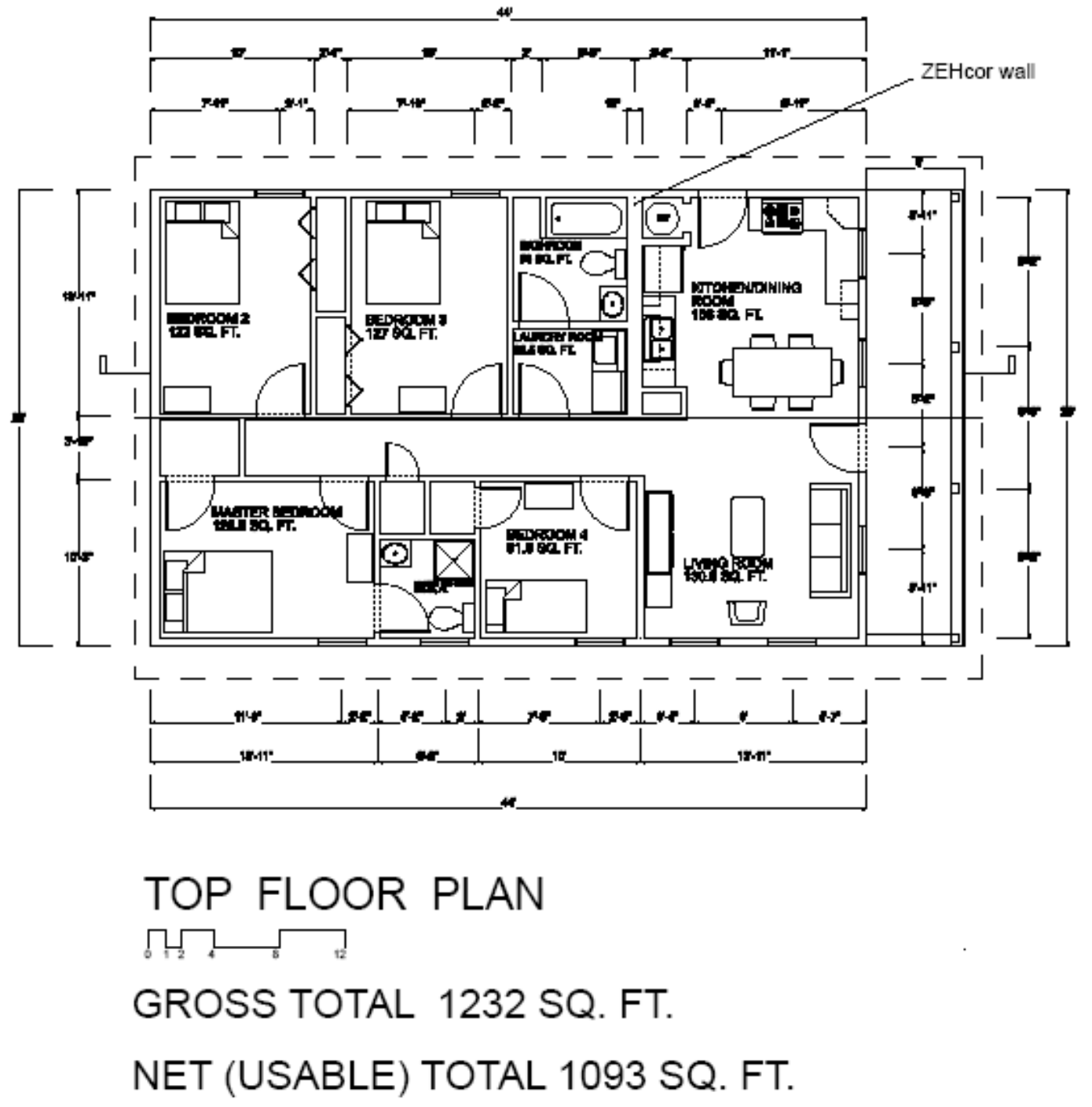

Fig. 7. Top floor plan of ZEH5. 

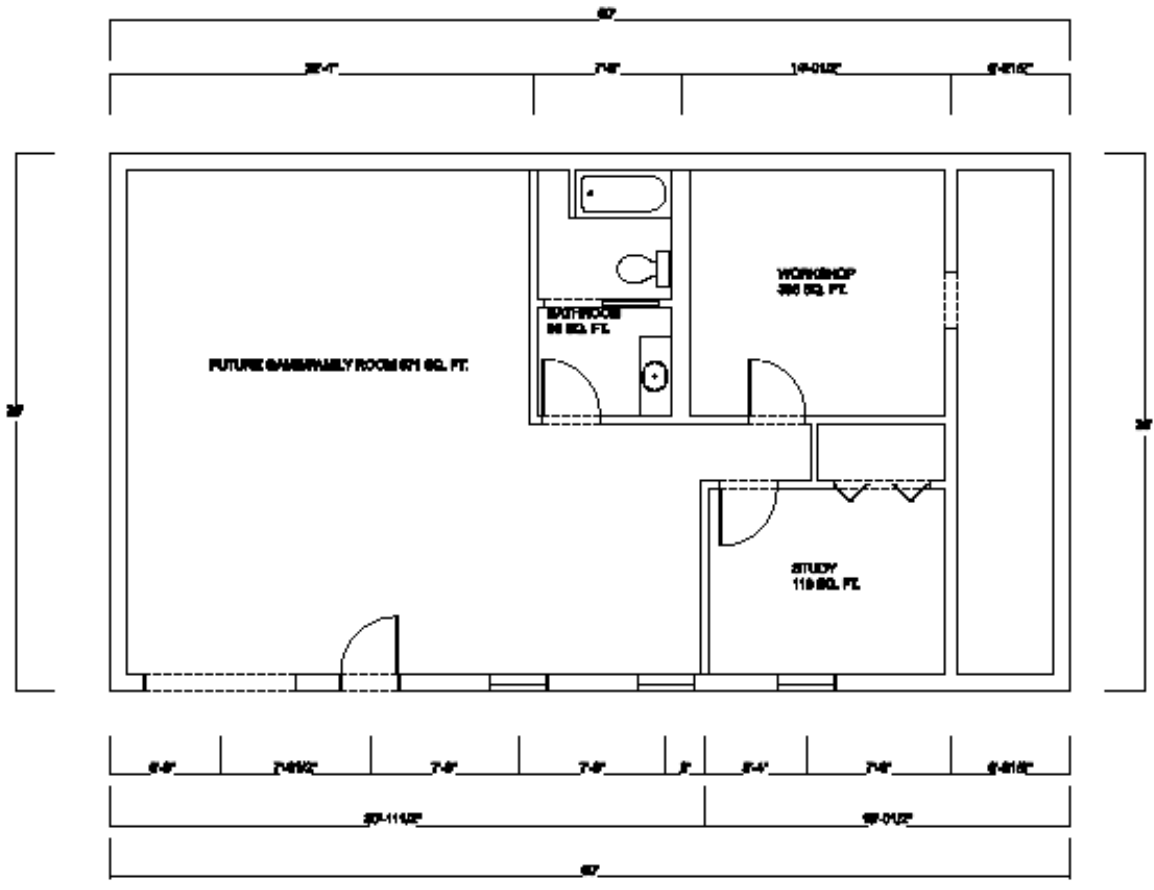

\section{BASEMENT FLOOR PLAN \\ GROSS TOTAL 1400 SQ. FT. \\ NET (USABLE) TOTAL 1220 SQ. FT.}

Fig. 8. Walkout lower level floor plan of ZEH5.

\subsection{ELEVATIONS}

Figures 9 through 12 show the four elevations of ZEH5.

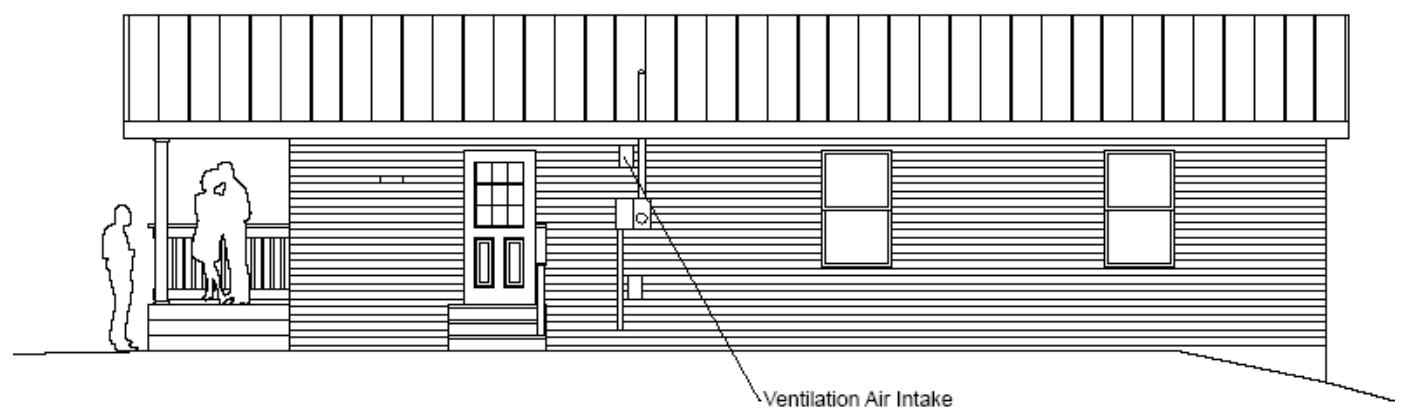

\section{NORTH ELEVATION}

Fig. 9. North elevation of ZEH5. Notice that the electric power feed into the house, ventilation air intake (high), and drier outlet (low) line up with the utility wall located between the kitchen, bathroom, and laundry room. 


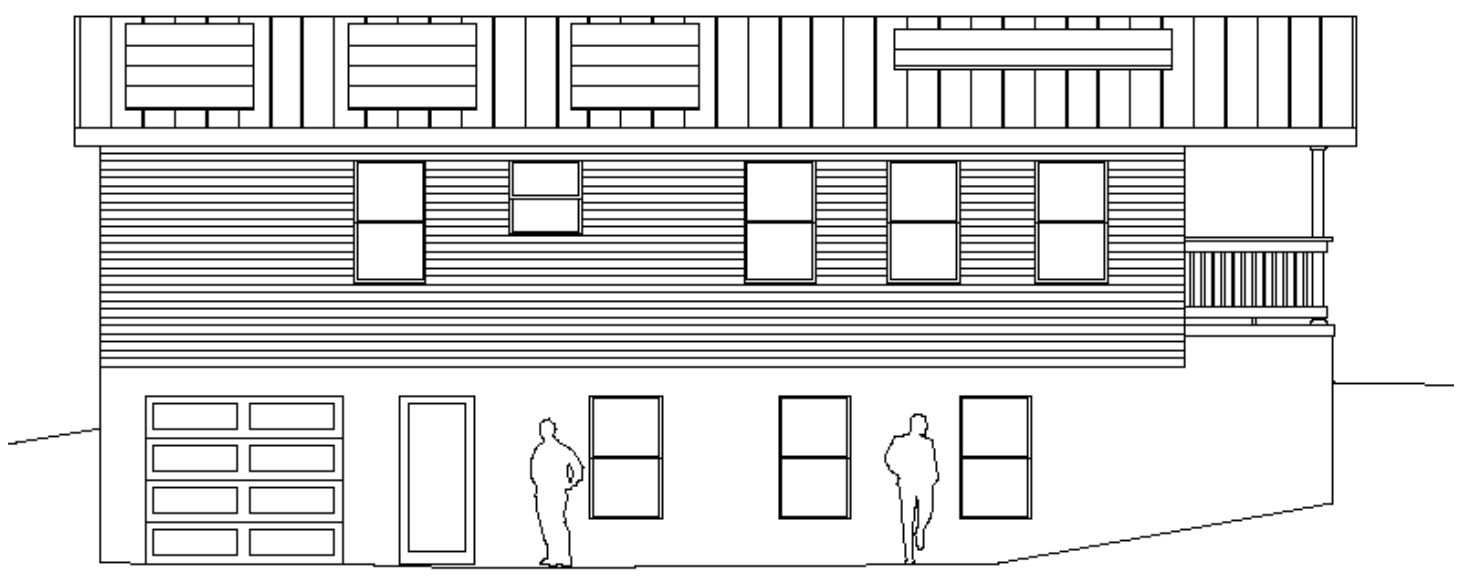

\section{SOUTH ELEVATION}

Fig. 10. South elevation of ZEH5. The collector area is to scale. Most of the windows are on the south side, which provides for very pleasant natural lighting. The garage door into the walkout lower level was intended to accommodate the Habitat for Humanity affiliate, which used this space for tool and construction material storage during the 3 year testing period before the house was made available to a family. The garage door, patio door, and three windows in the unconditioned walkout lower level are not included in the cost or energy modeling for the one-story house. (In September 2009, the homeowner removed the garage door and installed two $30 \times 50$ double-hung windows.)

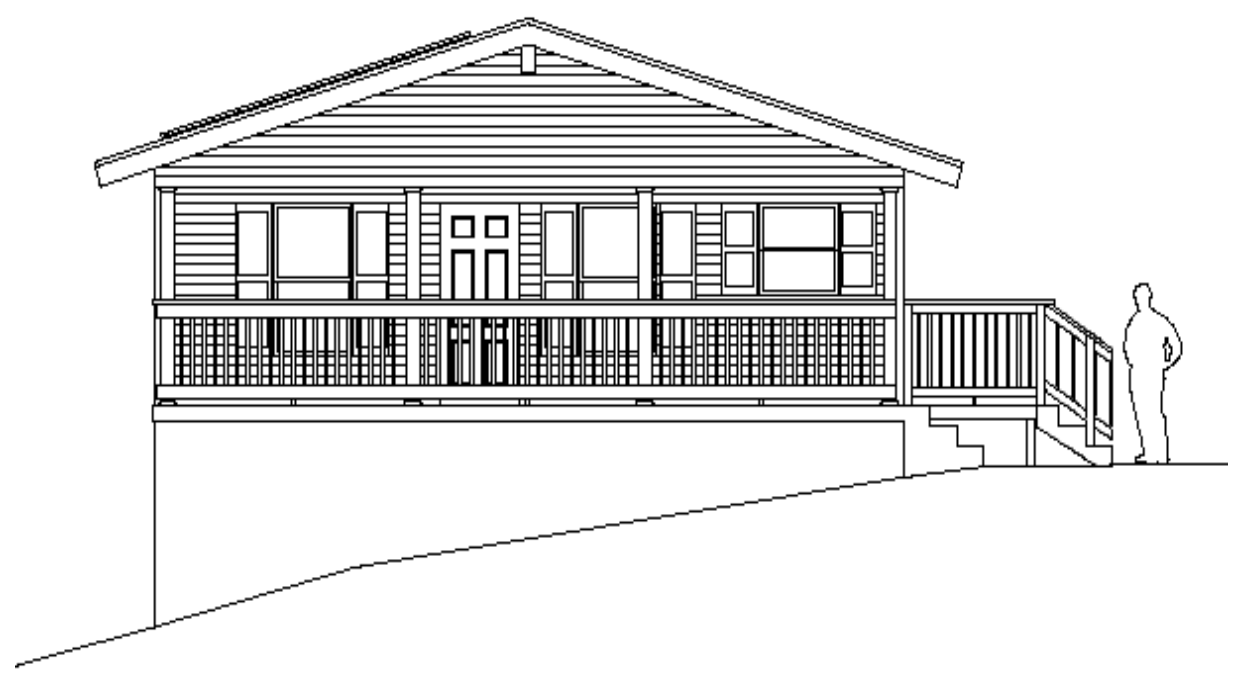

\section{EAST ELEVATION}

Fig. 11. East elevation of ZEH5. The full-length porch on the front is covered with SIP run out from the rest of the house. The space under the front porch is $8 \mathrm{ft} \mathrm{high} \mathrm{and} \mathrm{is}$ surrounded with R-10 board insulation on all exterior surfaces, including the bottom of the porch floor. Pouring a concrete porch on top of XPS insulation board requires careful tie-downs to ensure the boards do not float out of place during the pour. This did occur, requiring the masons to return and refinish the porch edge detail. 


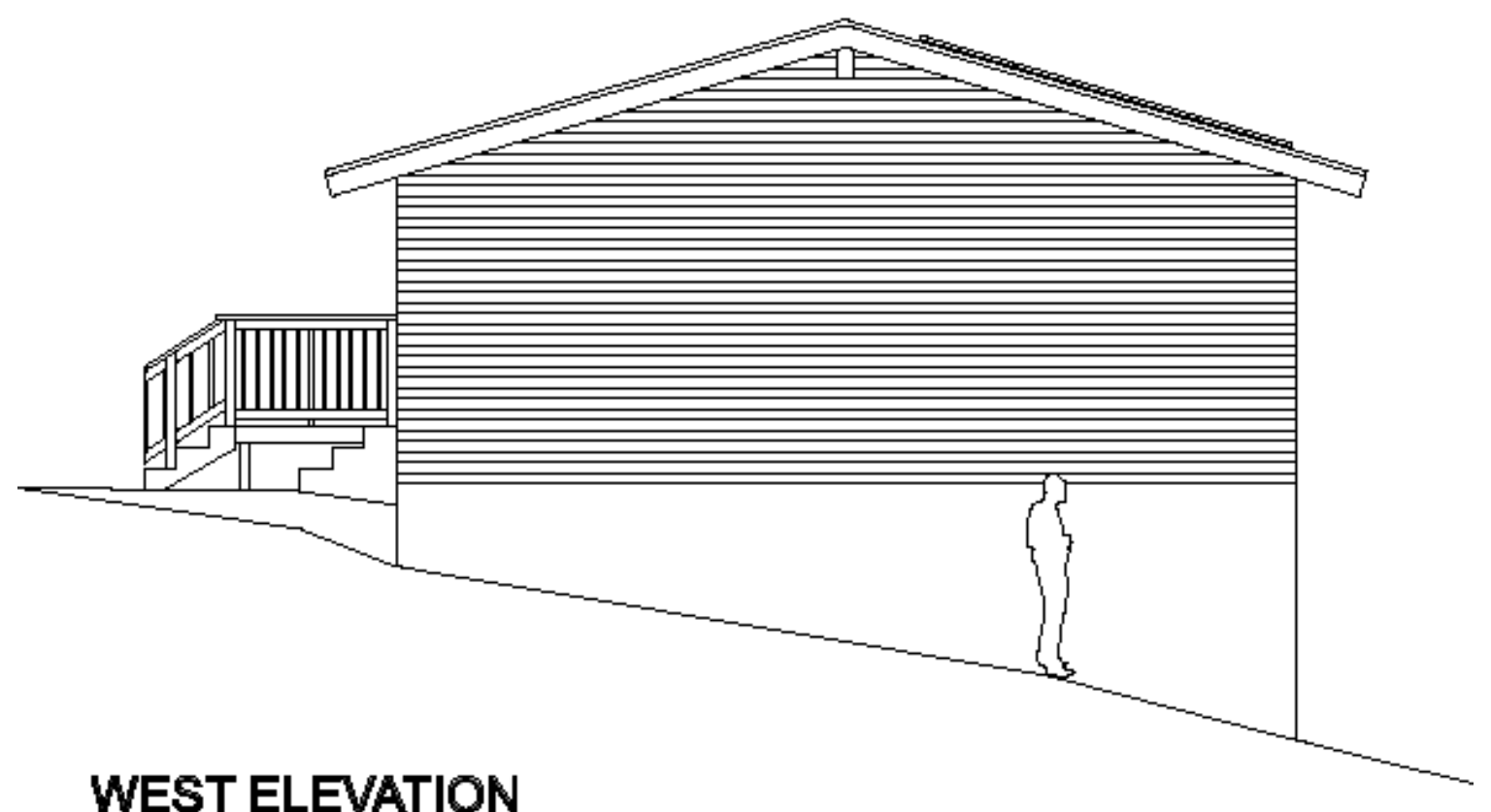

Fig. 12. West elevation of ZEH5. Habitat for Humanity has limitations on the number of windows allowed per house in this development. Modeling indicates that as many as four additional $3 \mathrm{ft} \times 5 \mathrm{ft}$ highperformance windows (with $\mathrm{U}$-values of $0.35 \mathrm{Btu} / \mathrm{h} \mathrm{ft}{ }^{2} \mathrm{~F}$ ) in this house would have very minimal impact on peak or annual energy loads.

\subsection{CROSS SECTIONS}

Figures 13 and 14 show the cross sections of ZEH5. The $52 \mathrm{ft}$ ridge beam shown in Fig. 8 was site-assembled with four $2 \times 12$ beams glued and bolted together to make a full-length beam that extended from the outside face of the west wall all the way to the outside edge of the front porch east gable overhang. Raising this beam into place must be done with a well-thought-out, safe lifting plan, considering the proper rigging, crane, and crew. It is recommended that Glu-Lam or some other type of engineered ridge beam be considered rather than site assembly with dimensional lumber. Of course, solid lumber post and beam construction is another option for a more upscale version of this house.

\subsection{STRUCTURAL INSULATED PANEL CUT DRAWINGS}

Figures 15-20 are from the SIP manufacturer, Premier Building Systems. These drawings start with the digital CAD files the builder sends to the SIP manufacturer. It is extremely important for the location and size of the rough openings for windows and doors to be correctly captured on these panel-cut drawings. Structural load points and wire chases should all be clearly marked. Noting thickness of the wall and ceiling panels and the type of splined panel connection is also critical. The floor and foundation interface details need to be clearly illustrated on both the builder's original drawings and on the SIP manufacturer's cut drawings. 


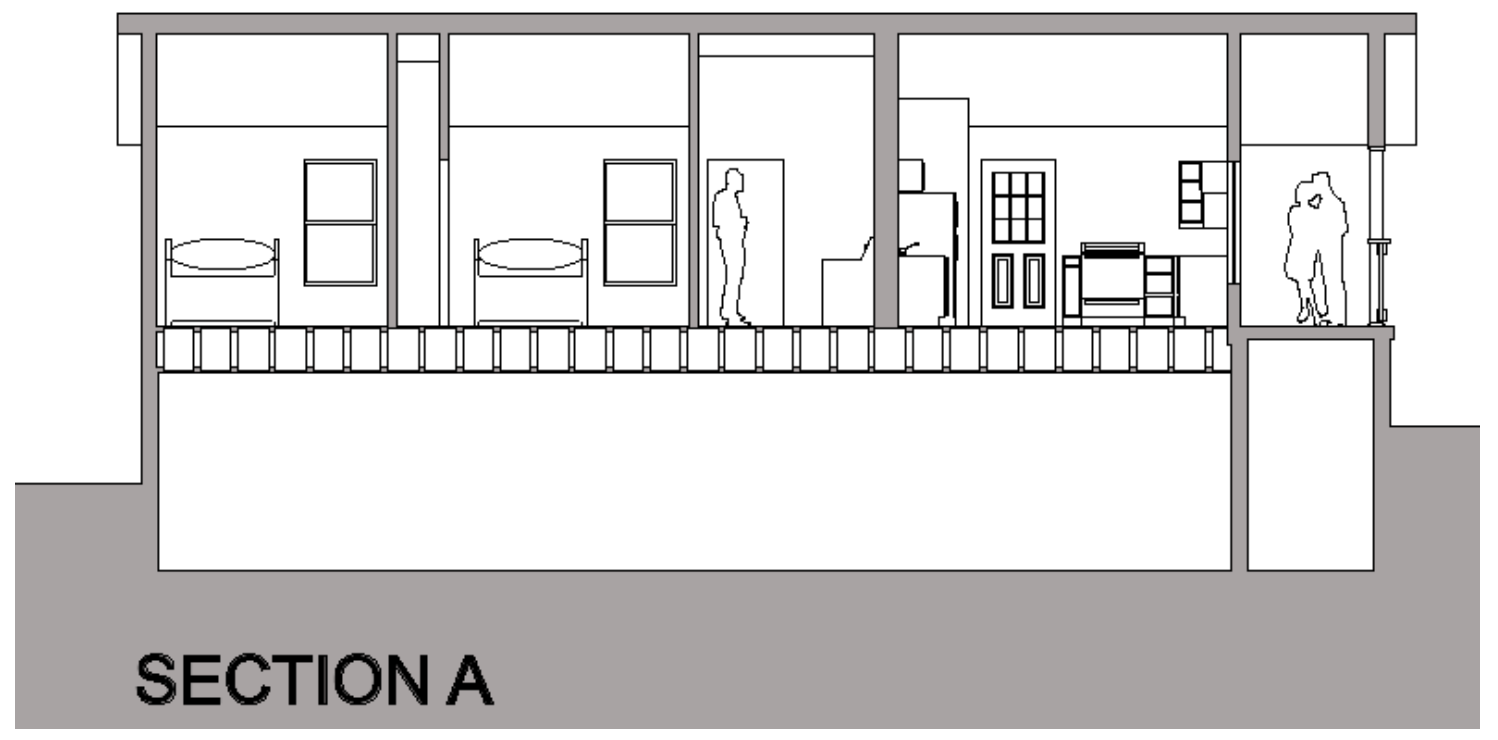

Fig. 13. Longitudinal section through ZEH5, the floor plan is shown in Fig. 7.

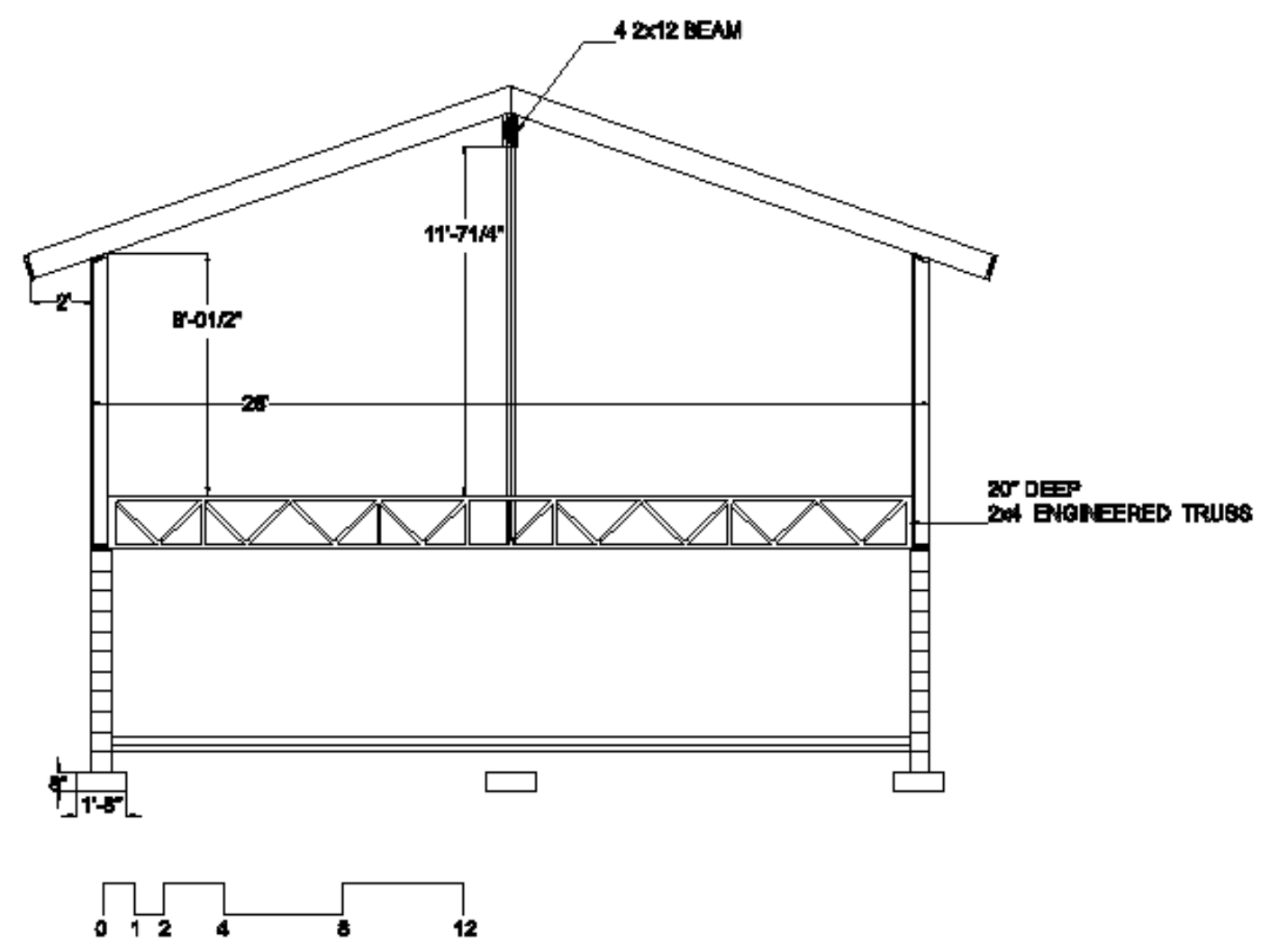

Fig. 14. Basic building cross section. 

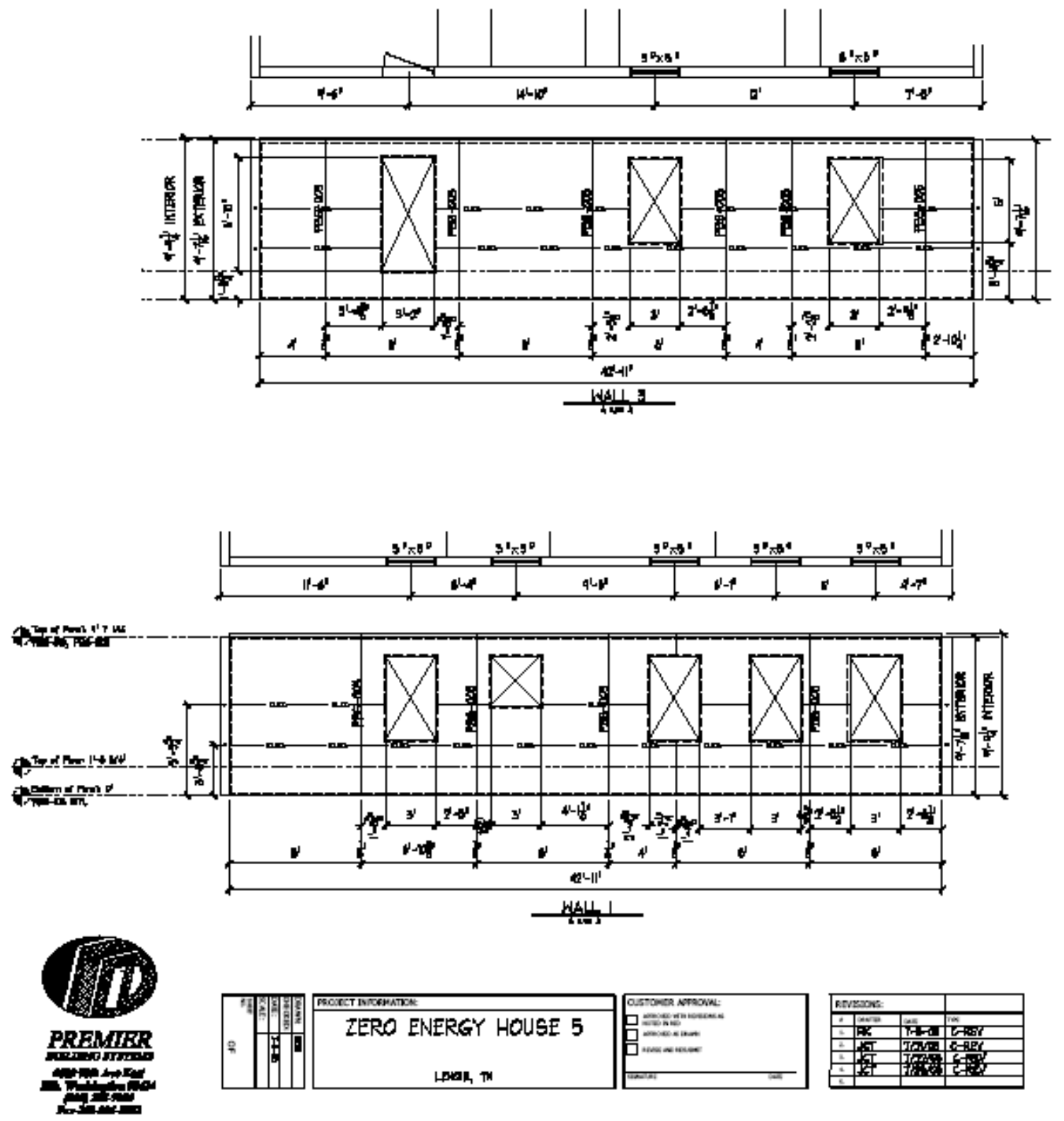

Fig. 15. Panel layout of the north (wall 3) and south (wall 1) walls. 


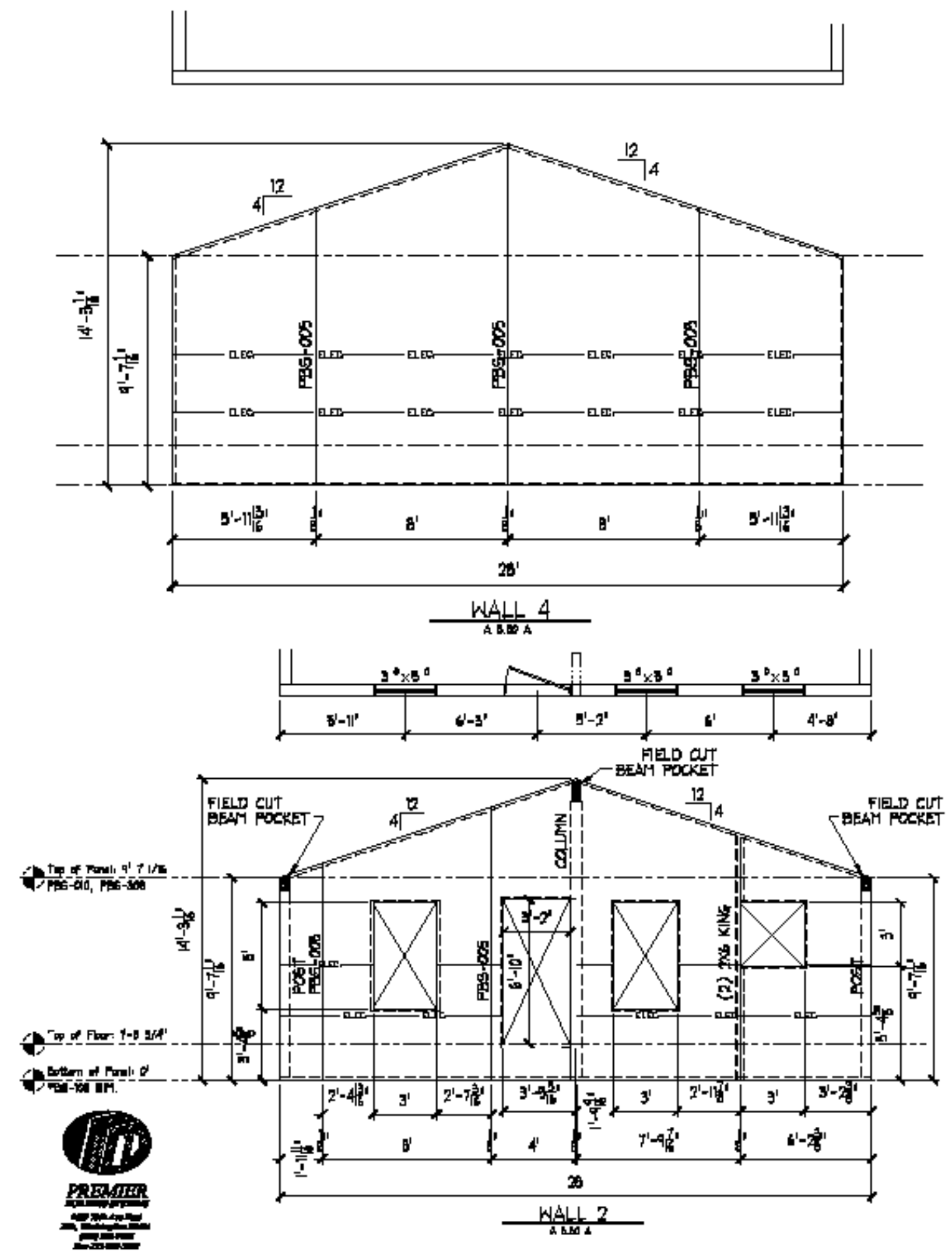

Fig. 16. Layout of walls 2 (east) and 4 (west). The west wall was modified on the site to contain a column to support the full-length ridge beam similar to that shown in the east wall. 

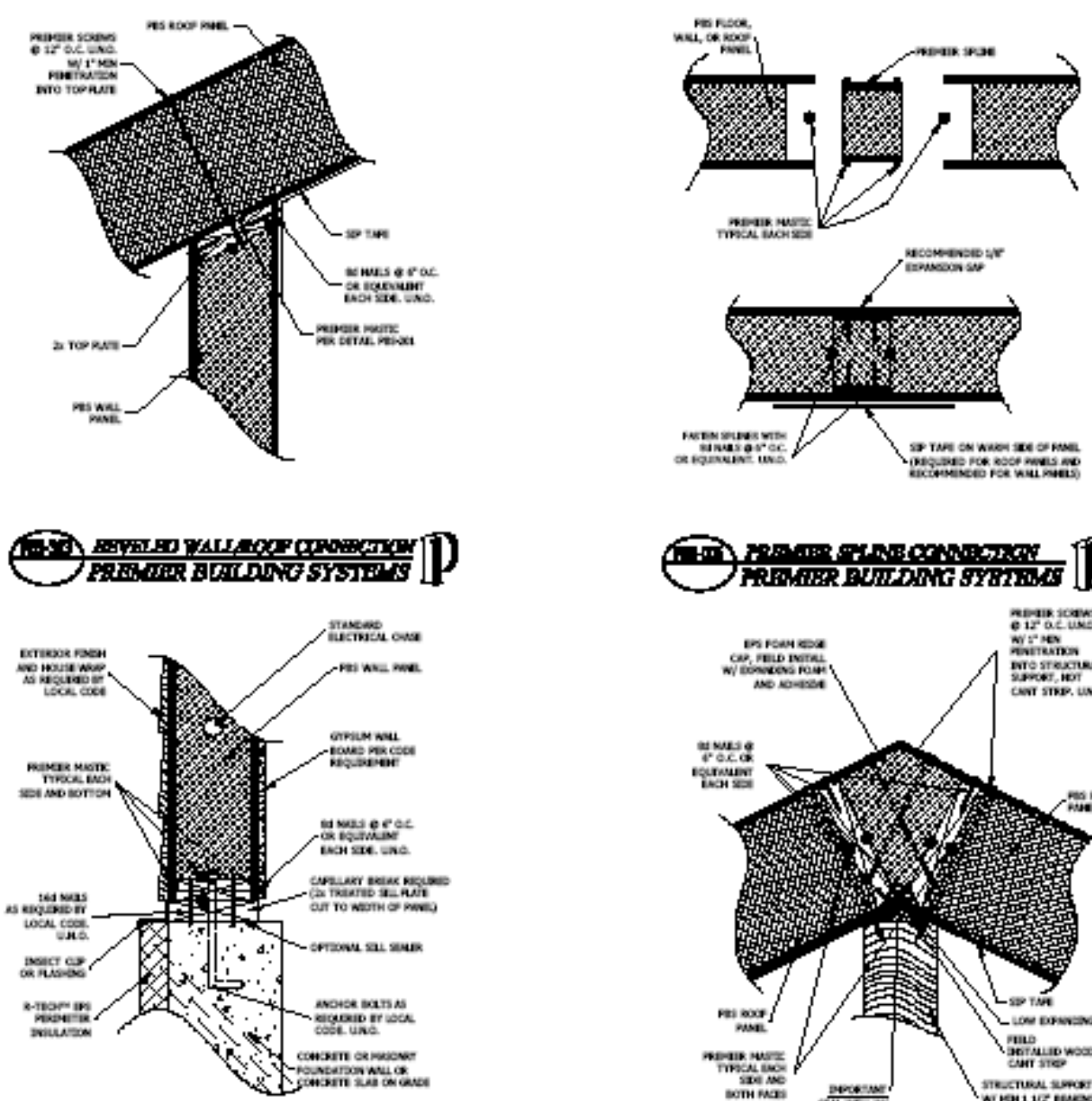

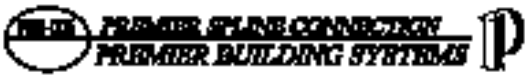
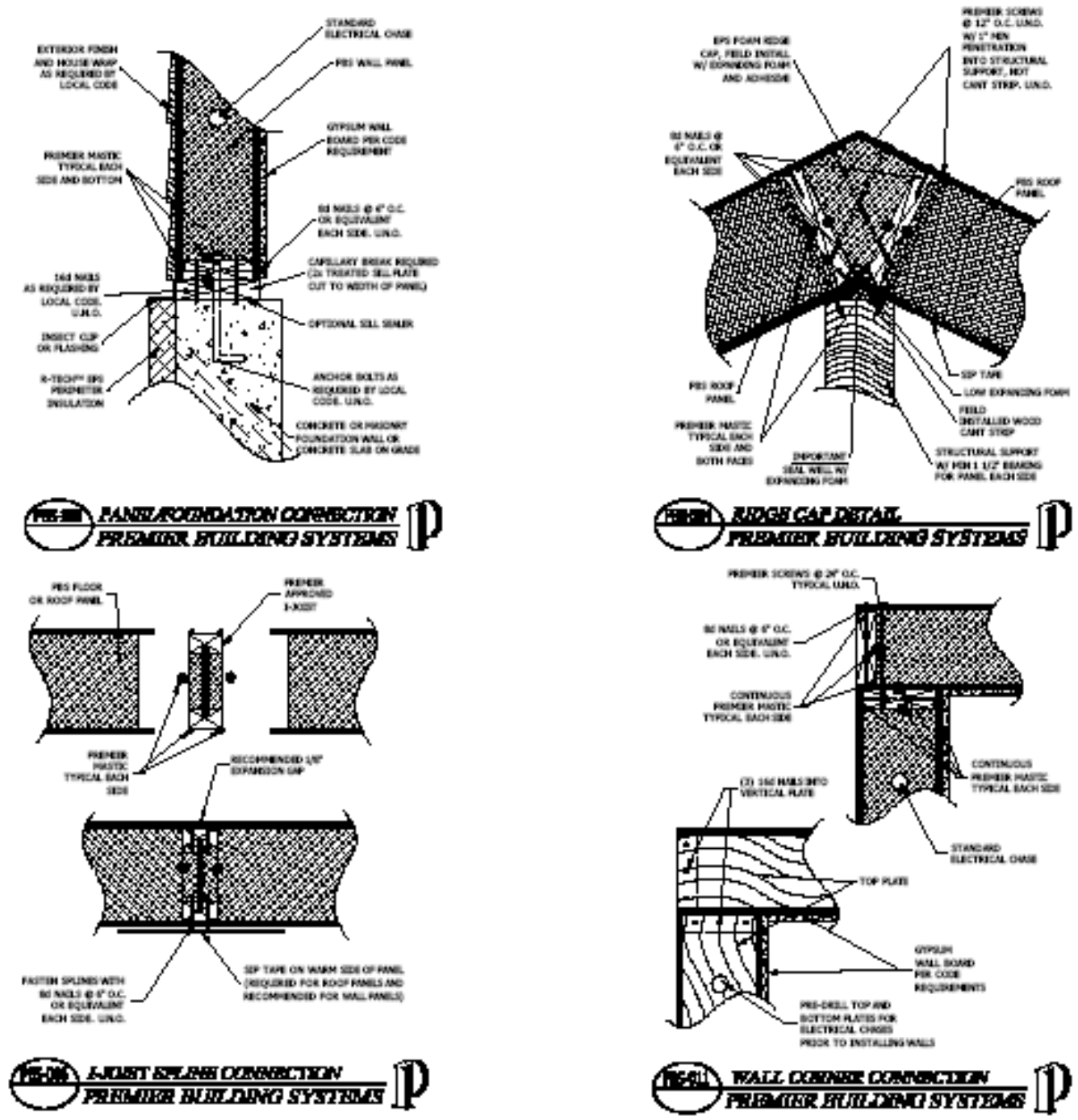

Fig. 17. Connection details. (The panel foundation detail shown in this figure was not used; see the foundation detail in Fig. 21.) 

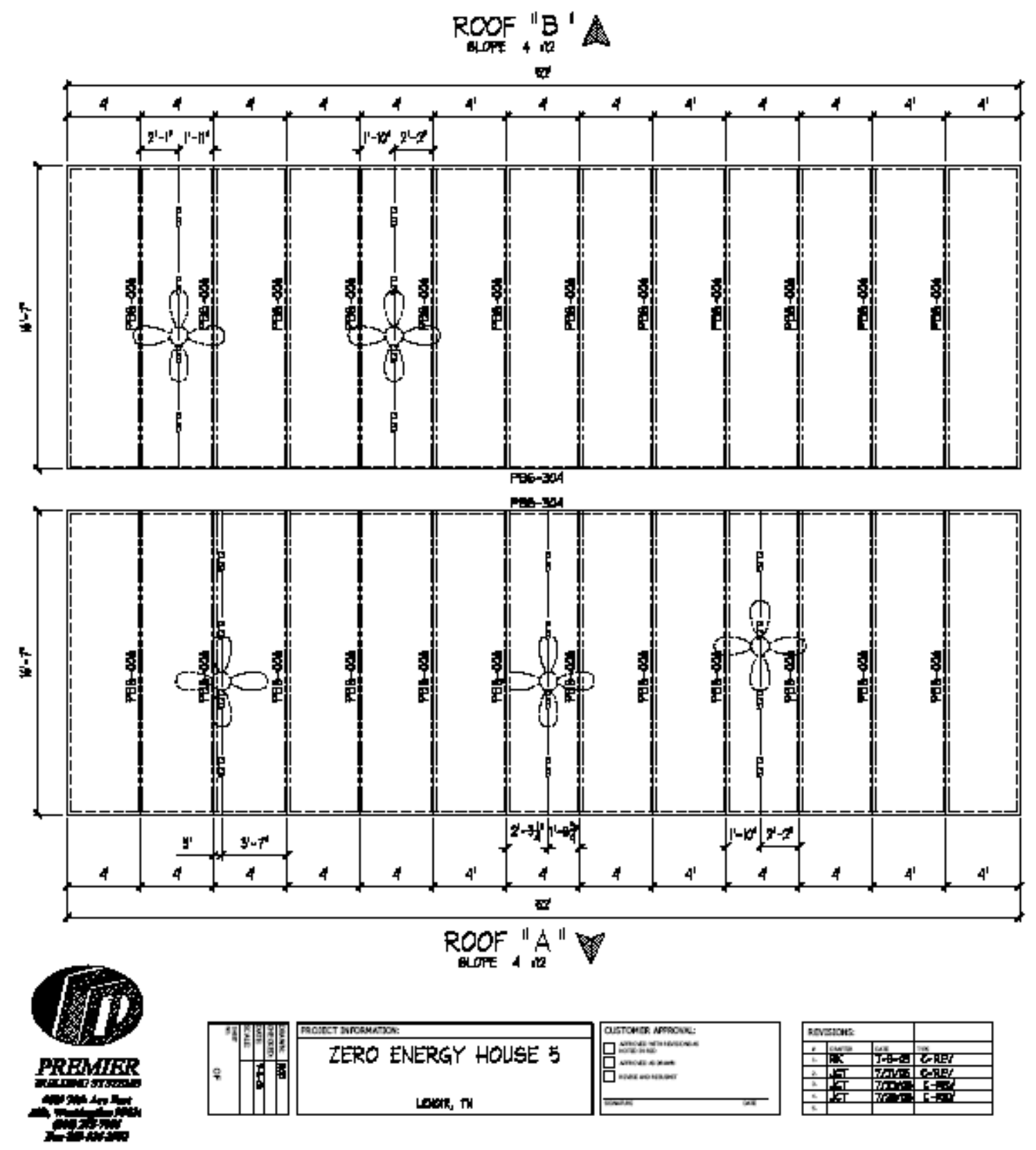

Fig. 18. Roof panel layout. These panels carry over the front porch. 

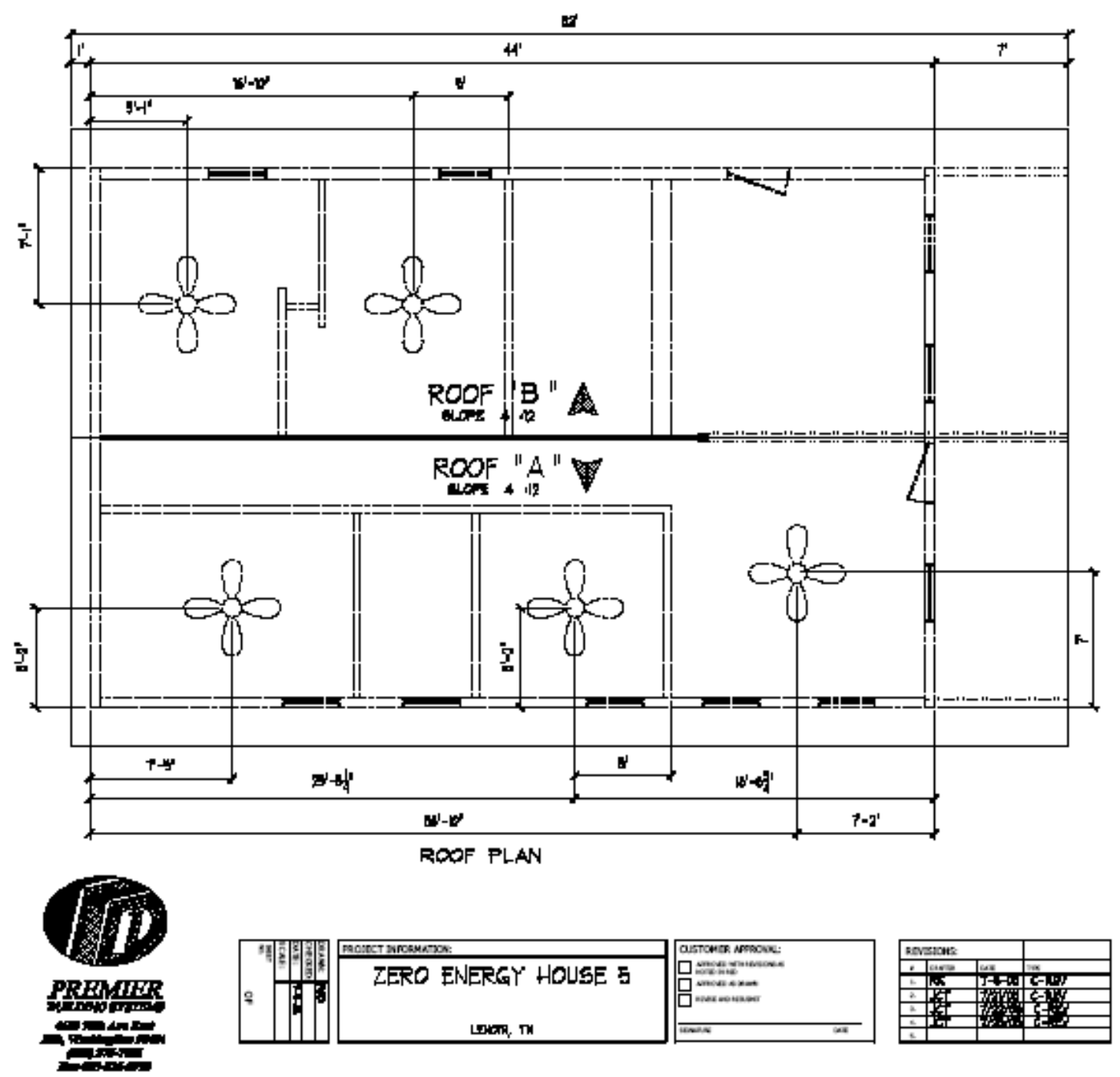

Fig. 19. Ceiling fan location and interior wall placement. The positioning of the ceiling fans is important; structural wood is necessary for secure fastening to the ceiling panels. Routing the wire chases to switches and power must also be detailed on these drawings. 

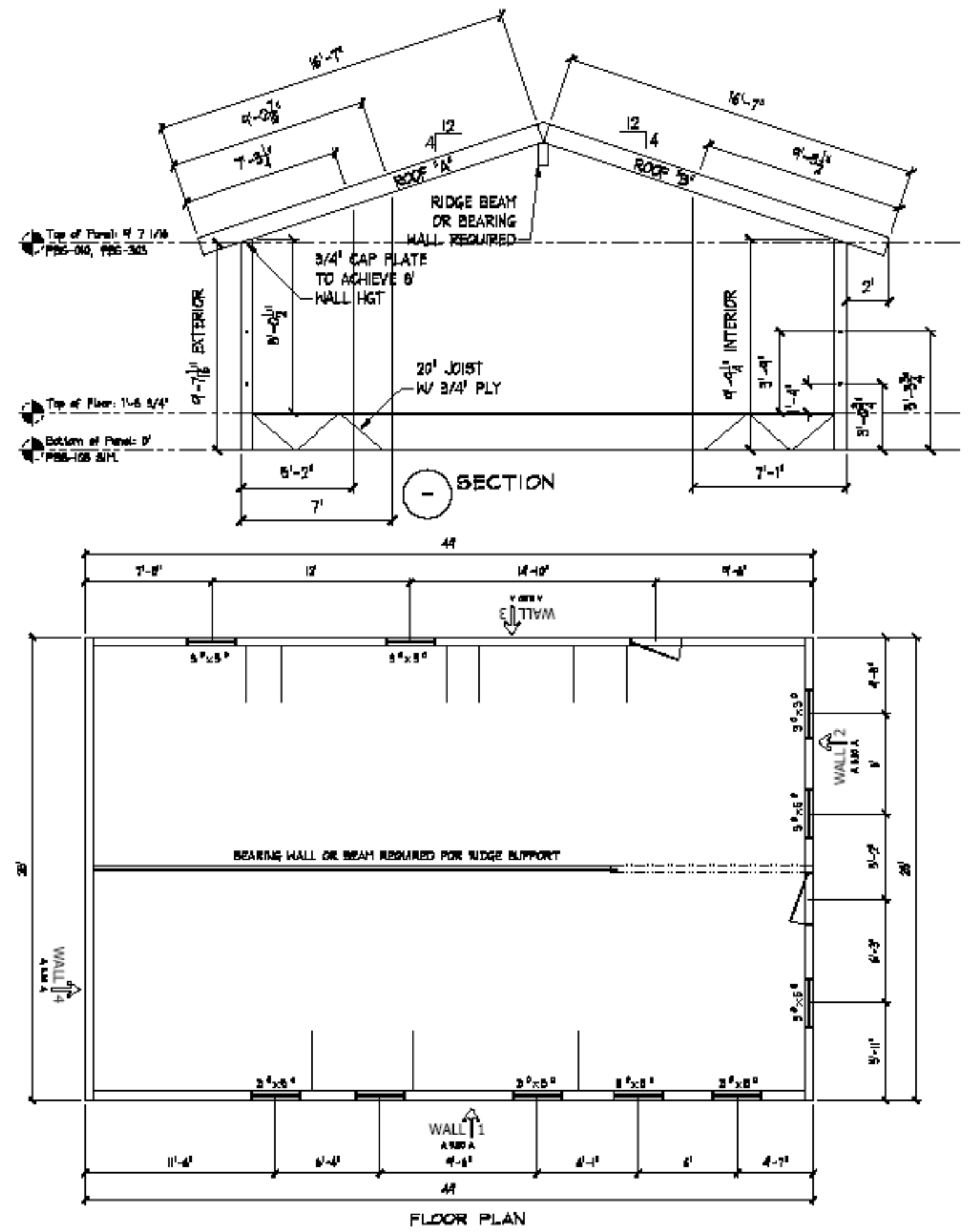

Fig. 20. Basic section and structure requirements. The extended overhangs are SIP, which provides substantial labor savings compared with site-assembled roof extensions. The drawing shows a partial ridge beam and bearing wall. The house was constructed with a continuous ridge beam with two intermittent structural support points that carried all the way down to a spread footer located below the walkout lower level floor. 



\section{SITE CHARACTERIZATION AND HOUSE ORIENTATION}

Selecting a site that allows this house an orientation to the south in the mixed-humid climate will make it easier to reach 50\% energy savings. This may mean picking lots or sites with views from the house to highlight those that are predominantly to the south. Allow for vegetative screens on the west side to minimize the impact of the hot sunny summer afternoons on the cooling load attributed to the building walls. Select the plantings carefully so that their mature height does not block solar access to the roof collectors. In the mixed and cold climates in the northern hemisphere, southern sloped lots are best for capturing maximum daylight all year, winter time passive heating, and ease of shading to minimize unwanted solar heat gain in the summer. Southern sloped lots that allow walkout lower levels not only capture more daylight and passive heating, but also provide lower-cost space and thermal mass, if the house is insulated and ventilated correctly, that contributes to annual energy savings and lower peak space heating and cooling loads.

In planned sustainable communities that ultimately want at least half of the house roof space preserved for PV panels and solar water collectors and do not want the modules to make a major visual statement from the street or the back yard decks, lots may be laid out with the longer dimension perpendicular to the street. This also allows for high density "streetscaping" in traditional neighborhood developments (planned urban developments) that continue to gain in popularity today. The narrow lot dimension reduces the street paving and utility infrastructure and allows land elsewhere in the development to be preserved. The garage could easily be located in the back of the house with an alley entrance. The ZEH5 plan provided in this report fits this more sustainable community site development.

As initially built, high performance houses with street and lot layout conducive to $50 \%$ energy savings should always allow for the later addition of solar PV and solar water heating. The general solution is to develop conservation communities with the housing in higher density patterns. Smaller lots are more conducive to the ZEH5 shotgun-style house plan detailed in this report (a look through the front door reveals the hallway from which all rooms are connected). Planned urban developments or conservation developments are allowed in many building zoning ordinances. This concept keeps the same number or more lots on the total development acreage and optimizes for the maximum number of solar access lots, allowing more homes to reach zero peak energy and ultimately zero annual energy. Preserving land gives the whole development the flexibility to include natural noise barriers, maximize solar access, and increase lot value. A general rule of thumb in East Tennessee is that every foot of road, with storm water, sewer, and potable water, adds $\$ 325-\$ 400$ to development cost (Henry 2007). This does not count the extent of excavation, which can vary depending on the amount of rock. More thoughtful layout of small, deep, long, narrow lots with minimum road and utility distribution expense and maximum solar roof access increases infrastructure cost savings.

ZEH5 was modeled using EnergyGauge (FSEC 2006) and then rotated in each cardinal direction, north, south, east, and west. The heating and cooling energies for a south-oriented ZEH5 were given in Table 5; Table 11 shows the percentage that heating and cooling energy use would increase if the house were oriented in the other three cardinal directions.

Table 11. Increase in calculated heating and cooling loads for ZEH5 when modeled house is oriented to east, west, or north

\begin{tabular}{lc}
\hline & $\begin{array}{c}\text { Percent higher than } \\
\text { true south orientation }\end{array}$ \\
\hline East & $7.9 \%$ \\
West & $7.7 \%$ \\
North & $9.5 \%$ \\
\hline
\end{tabular}





\section{ENVELOPE SPECIFICATIONS}

\subsection{FOUNDATION (WALKOUT LOWER LEVEL)}

Figure 21 shows an exterior insulated foundation similar to that used in ZEH5. ZEH5 actually used a standard 10 in., hollow-core (2) block wall with the floor truss resting on top of the wall rather than the 12 in. suspended floor trusses as shown. However, the rest of the detail is as built.

The waterproofing, insulation, and above-grade finish system is from Tremco (www.guaranteedDryBasements.com). The waterproofing is a water-based polymer/asphalt sprayapplied membrane as shown in Fig. 22. It is applied wet, 60 mil thick, directly to the outside of the below-grade masonry wall after the mortar is dry and all loose aggregate and sharp protrusions have been removed. The water vapor permeability of the waterproofing is reported by Tremco to be 0.08 perm for a 40 mil dry coating using the ASTM E-96 dry-cup method. The waterproofing should be covered quickly to avoid unfavorable drying results, like interconnected cracking or "alligatoring."

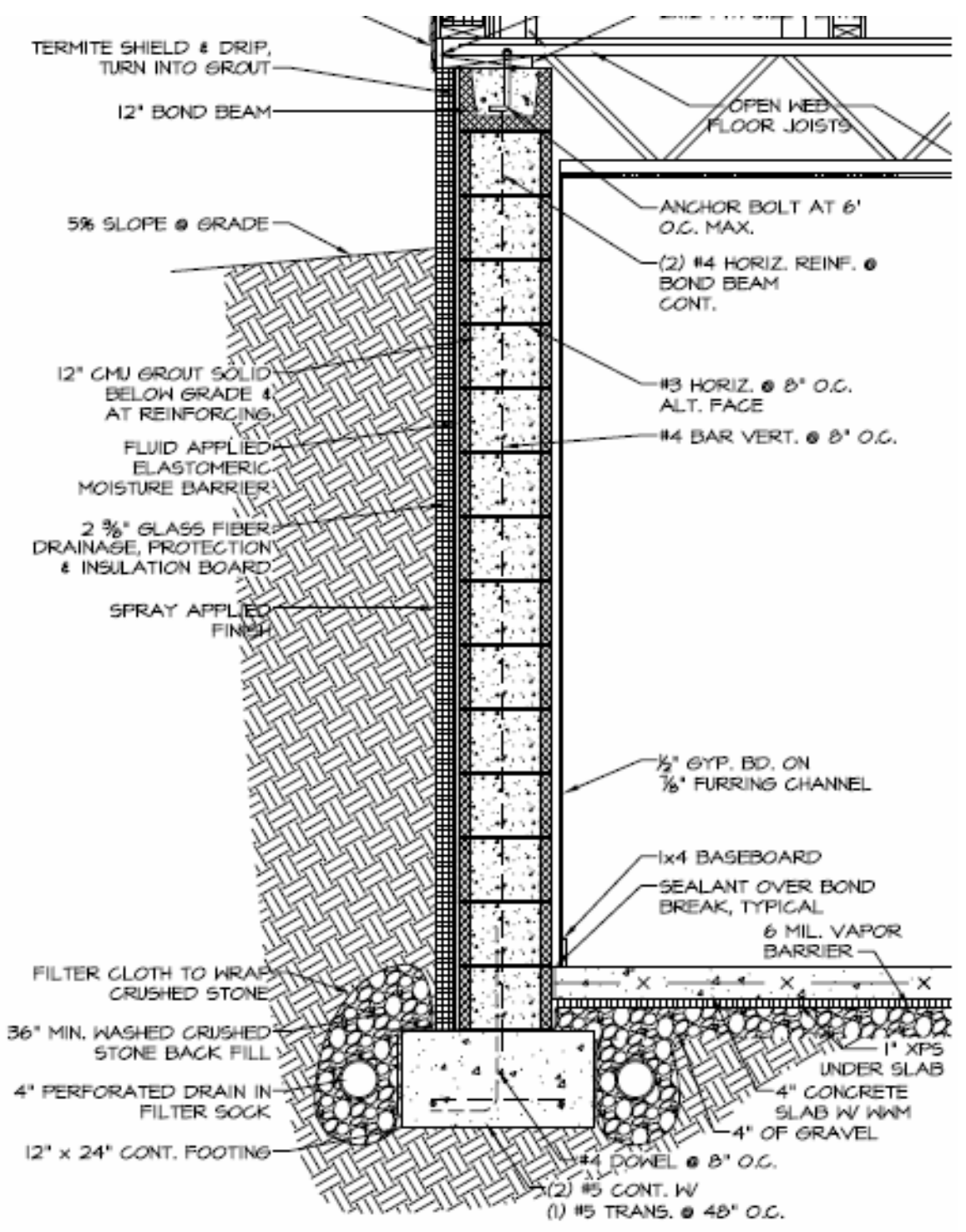

Fig. 21. ZEH5 foundation detail, Eason Architects, 2007. 


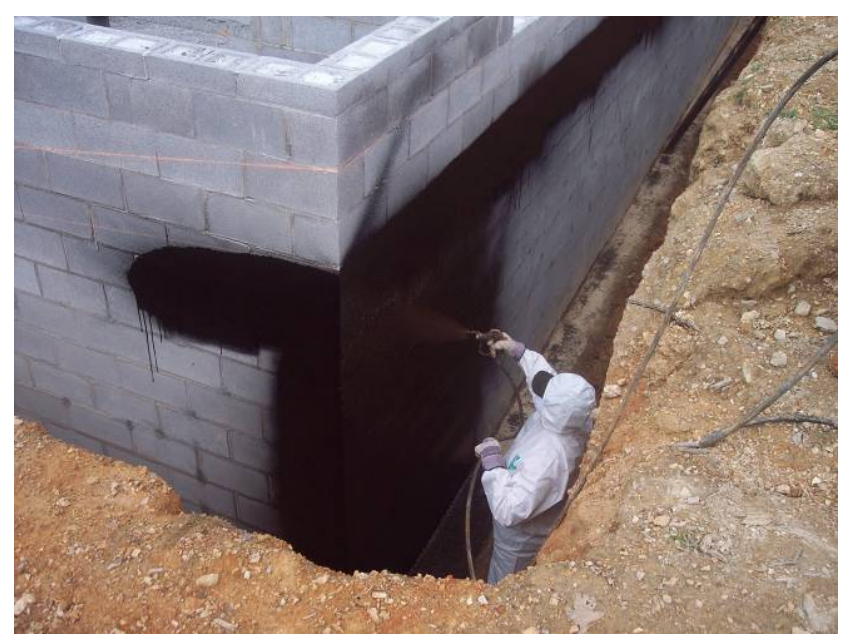

Fig. 22. Waterproofing. For OSHA compliance, the over cut of the house must be sloped $45^{\circ}$ for depths greater than $5 \mathrm{ft}$.

Fiberglass drainage board, $23 / 8$ in. thick with a density of $6 \mathrm{lb} / \mathrm{ft}^{3}$, is placed over the waterproofing as it cures, as shown in Fig. 23. The walkout lower level wall that is exposed above grade was covered with $9 \mathrm{lb} / \mathrm{ft}^{3}$ fiberglass board. The higher density was necessary to provide a firmer substrate on which to apply the elastomeric-emulsion-based coating above grade. This insulated board is mechanically fastened to the wall and has mesh reinforcing on the outside surface. The lowerdensity below-grade board's R-value was measured at ORNL according to ASTM C518 to be $10.0 \mathrm{hft}^{2}{ }^{\circ} \mathrm{F} / \mathrm{Btu}$. The higher-density above-grade board was measured at $10.2 \mathrm{hft}^{2}{ }^{\circ} \mathrm{F} / \mathrm{Btu}$.

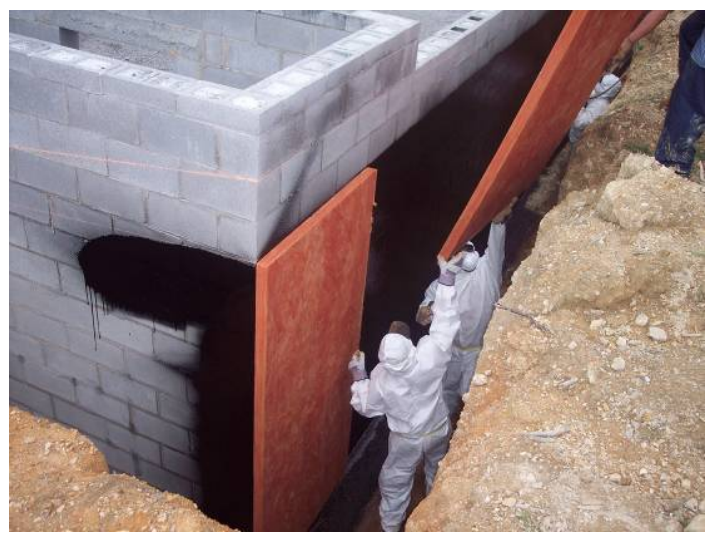

Fig. 23. Installation of $4 \times 8 \mathrm{ft}$ fiberglass boards sized to cover the waterproofing.

The exposed fiberglass above grade is covered with Tremco's "Horizon Foundation Finishing System." Mesh strips are fastened over seams as well as the mechanical fastener indentations. A "fill" material is used to cover these locations to make the insulation a uniform surface for spray-applied elastomeric coating. The preparation around inset windows (shown in Fig. 24) to place the window inside the drainage plane and still avoid thermal shorts can be rather labor intensive but is a much better solution to minimizing moisture ingress. Whenever possible, the fasteners should be located slightly below grade when only small above-grade wall areas are needed between grade level and the top plate. For larger areas, the mechanical fastener indentations will need to be filled and leveled to avoid telegraphing through to the final surface. This system was installed in 2005, and in November 2009, there was no visible damage anywhere to the above-grade finish. Unlike many of the conventional foundation walls in the neighborhood, there are no mud stains on this foundation.

The final step is the spray-applied paint. Figure 25 shows this coating being sprayed onto the elastomeric coating. If the paint is applied in high humidity, common in the hot humid/mixed humid climate, there should be no contact to the surface for at least 24 hours. According to the manufacturer, the 40 mil coating has a water vapor permeance of 6 perms as measured using ASTM E-96. 


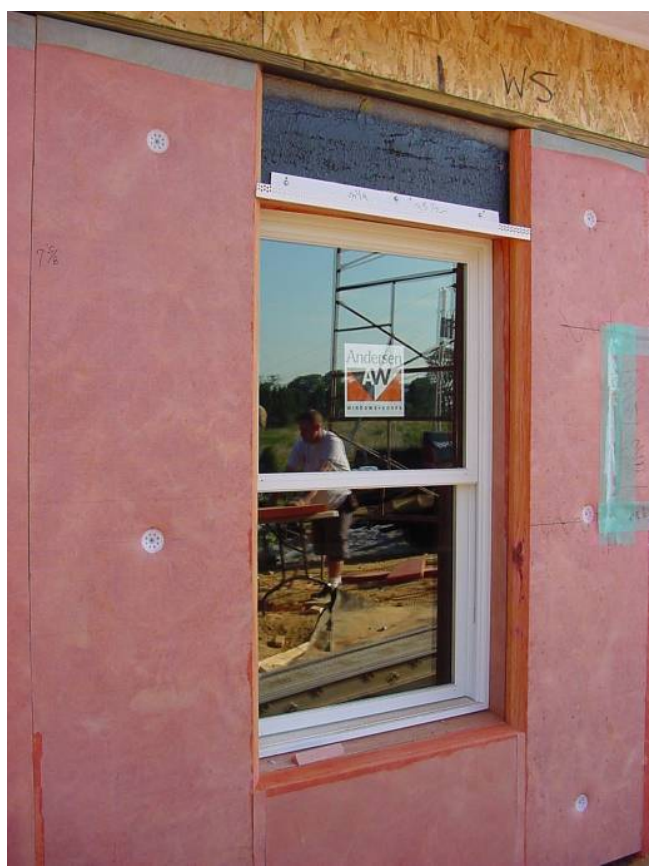

Fig. 24. Detailing around inset windows to avoid thermal shorts and minimize water penetrations is very important.

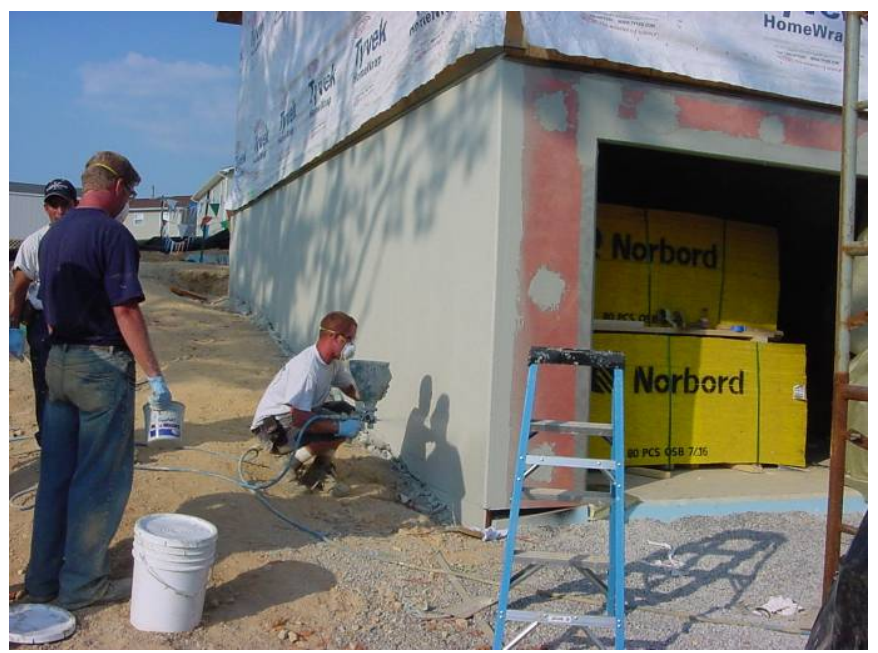

Fig. 25. The above-grade portion of the foundation wall receiving final spray covering.

The foundation system is complete once the footer drains are run to daylight. Figure 26 shows footer drains on both the inside and outside of the first course of the walkout lower level block wall. These perforated drains were connected to a 4 in. plastic pipe with no holes sloping away from the foundation and run to daylight on the southwest corner of the house. The foundation system in ZEH5 has been completely leak-free from 2005 up to the time of this report.

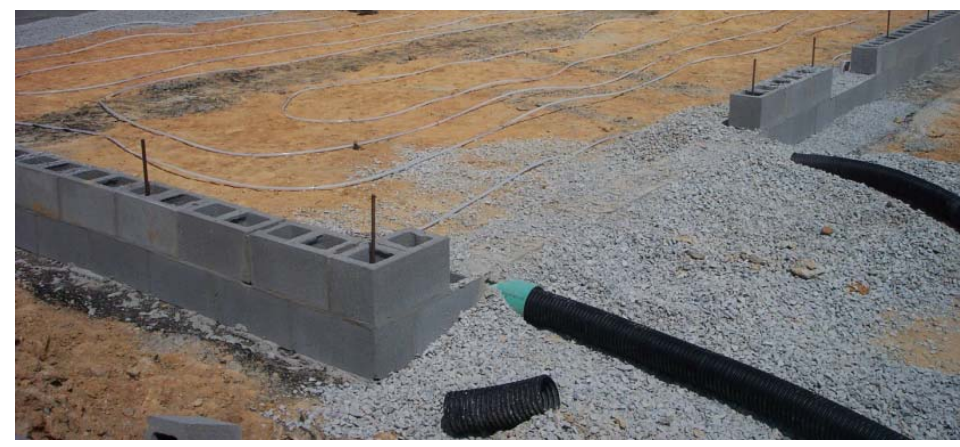

Fig. 26. Footer drains run to daylight on both sides of the wall below the walkout lower level floor.

\subsection{WALLS-STRUCTURALLY INSULATED PANELS}

SIP houses, when designed correctly, have few thermal shorts, and our first-hand experience with six test houses demonstrated that they are consistently easier to make airtight than stick construction. Blower door tests before and after drywall installation showed that the final anticipated airtightness was the same as that measured before drywall. This makes it easy to seal the most likely sources of overlooked leaks, which tend to be through the base plate of interior walls where most of the utilities come from the crawl space and unconditioned attics into the conditioned space. 
The peel-and-stick tape manufactured by Ashland Chemical (see Appendix B, Resources) was used at panel-to-panel seams and is recommended. The ridge and wall roof interface as well as all roof and wall seams at the corners and straight panel-to-panel connections were carefully taped as shown in Fig. 27.

Appendix B contains a list of SIP manufacturers that provide precut kits for houses like ZEH5.

Todd Helton is the Habitat for Humanity Loudon County Affiliate Construction Supervisor and was the Certified Union Carpenter Trainer on ZEH2, ZEH3, ZEH4, and ZEH5). He provided several important considerations for builders to consider when working with SIP; these are discussed below.

1. Trained personnel. Either train yourself or

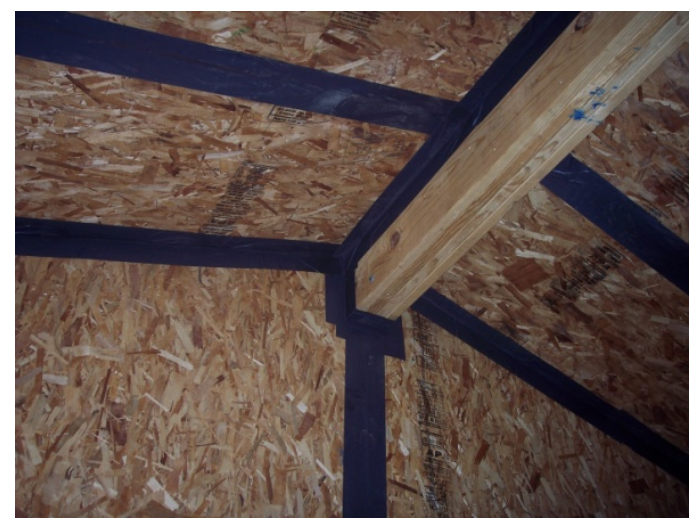

Fig. 27. Peel-and-stick panel tape provides added assurance that panel seams will remain airtight. have trained personnel involved in the project as early as possible. The affordable ZEH project at ORNL has spawned three educational programs that include this training: Brotherhood of Carpenters Union, University of Tennessee Department of Architecture, and Cleveland State Construction Management 2 year junior college.

2. Panel quality. Avoid damaged panels - they take more time to install. Coordinate with SIP manufacturer to load and ship panels to minimize their handling on site. Panel protection begins with on-site staging by well planned unloading and stacking high, dry, and flat. Usually, the contractor is responsible for unloading the truck when the SIP arrives unless predelivery arrangements have been requested. Be prepared to stage the panels in a logical manner, with first up at the top of the pile closest to the foundation. Avoid scheduling all work around the outside of the foundation so as not to disturb the efficient and safe installation of the panels.

3. Proper equipment. An equipment list for installing SIP includes a boom truck and roper rigging for lifting the ridge beam and SIP ceiling panels. An all-terrain forklift will also come in handy. For the occasional panel adjustment, foam hot wires and panel (beam) cutter should be on site. Beam cutting attachments are available to fit worm-drive circular and electric chain saws. If the foundation layout is not square, one or more of the panels may have to be cut. Foam scoops are usually supplied as part of your SIP package. The "barbeque starter" type foam scoops have a radius in the corners of about $1 / 2$ in. and the corners are not squared, so a pass must be made with the iron turned 90 degrees to square the corners. On all five of the test houses, the SIP manufacturer provided the caulk; one provided a power caulker. ZEH5 has $930 \mathrm{ft}$ of panel seams. The wall/floor and wall/roof each require 4 beads of caulk totaling $1792 \mathrm{ft}$; the wall/wall and roof/roof seams each take 6 beads of caulk totaling $3492 \mathrm{ft}$; and the ridge detail requires 8 beads of caulk totaling $416 \mathrm{ft}$. In all, ZEH5 required $5092 \mathrm{ft}$ of caulk for the SIP; in other words, enough caulk to go from goal line to goal line on a football field 17 times! (Get a power caulker.) The SIP manufacturer can also install splines in one of the panels, which saves site assembly time.

4. Foundation accuracy. There is less tolerance in SIP construction than in stick construction for lack of plumb, level, and square. The top of the foundation needs to have provisions for a termite shield and capillary break. This can be an aluminum flashing traversing the top of the foundation from inside to outside the wall surfaces. It is also important that the outside skin of the SIP be fully supported to avoid creep and loss of structural integrity. Double-check to ensure the dimensions for the footer, foundation wall, and floor on the design drawings are accurate, and follow up with measured confirmation of plumb, level, and square of the footer, foundation wall, and floor during construction. The foundation for ZEH5 was not as square as desired. The end result was that a 4 in. SIP wall section needed to be fabricated on site and added to the north wall. 
Figure 28 shows the foundation/floor/SIP wall detail used on ZEH5. Some floor truss lengths can be slightly shortened on site. This is recommended to allow unanticipated adjustments that might be necessary to make sure a good seal can be made at the floor/wall interface. The outside facing of the SIP must have continuous structural support for the full length of the bottom edge. It is best to leave a small gap between the SIP wall and the end of the floor trusses (install backer-rod and caulk seal) than to hang the SIP face over the edge of the top plate. The concrete subcontractor needs to understand that a SIP foundation must be closer to square, plumb, and level than the typical residential construction industry-accepted standard.

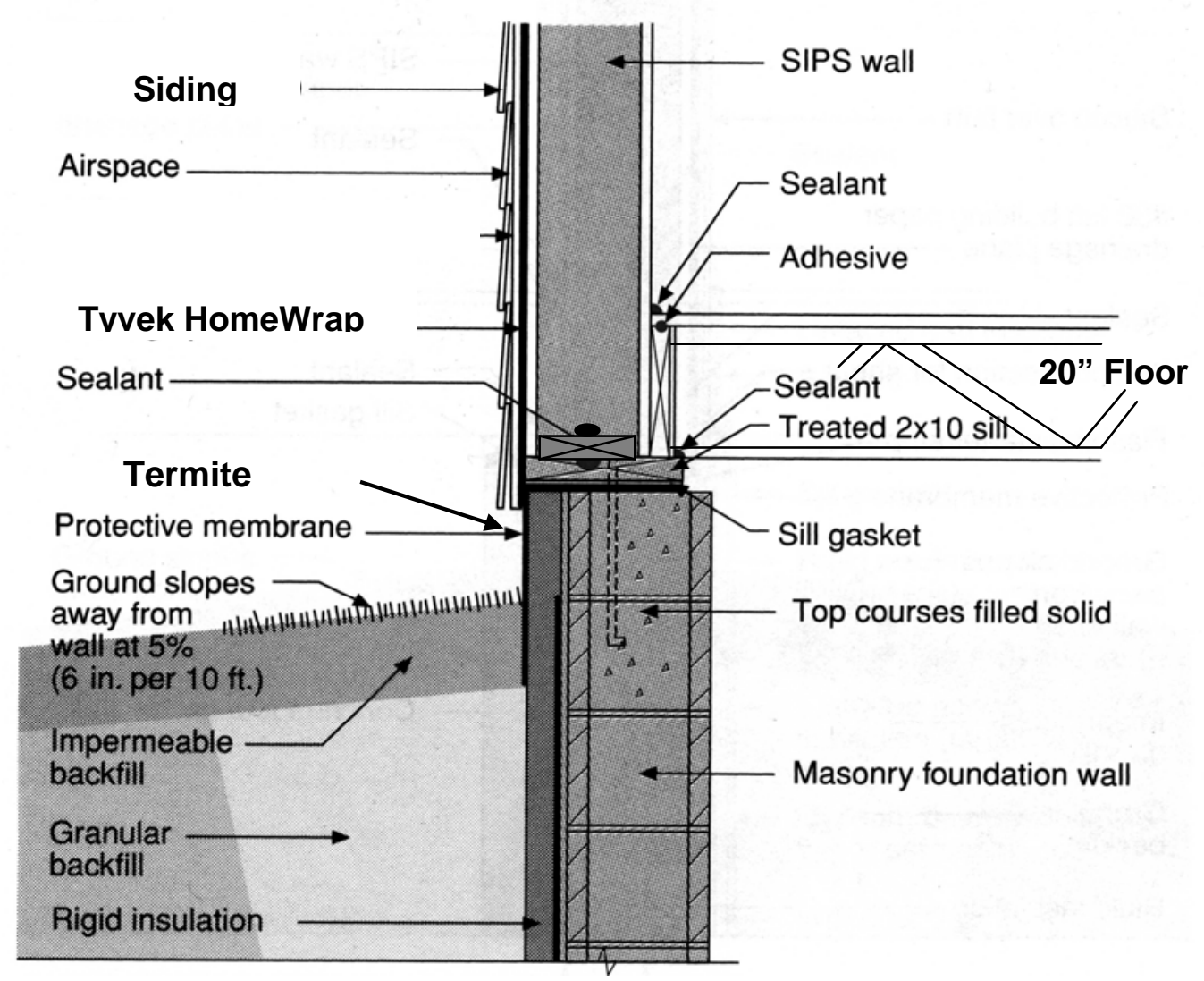

Fig. 28. ZEH5 Foundation/floor/SIP wall detail.

5. Drain plane. Each of the five houses was wrapped with DuPont Tyvek (www.tyvek.com) and the window/SIP interface was stringently checked to attain the above-grade wall drainage plane. Pans that drain only to the outside under each window and door were also included as shown in Fig. 29. The drainage plane must be continued at the base of the first floor with flashing that directs any winddriven rain water away from the wall at the wall/foundation junction. This flashing can be seen in Fig. 25 right below where the Tyvek house wrap stops and is also on the drawing in Fig. 28.

A roof drainage plane is recommended when installing an SIP roof. Figure 30 shows the drainage plane between the \#30 felt paper and the raised metal seam roof. This gap not only provides moisture control, it also provides a cavity in which natural convection will help keep the hot summer heat from penetrating into the conditioned space and that will contribute to the cooling of the underside of the solar modules. The panel clip fastened to the SIP holds the metal roof about 1/4 to 3/8 in. off the \#30 felt, providing a continuous drainage area. The highest temperature of the metal roof was recorded on August 26, 2009, at $157^{\circ} \mathrm{F}$. In the air gap under the metal roof and above the felt paper, the highest 

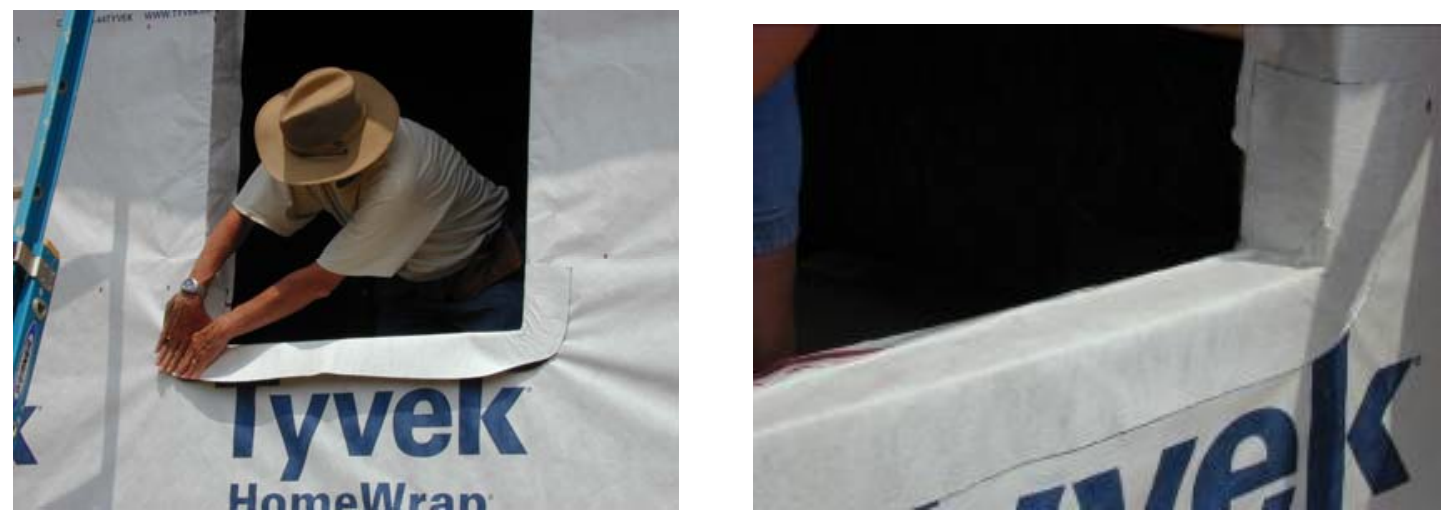

Fig. 29. Panned window opening.

temperature recorded was $146^{\circ} \mathrm{F}$. The 8.5 in. SIP roof was overlaid with 2 in. of XPS ;the highest temperature recorded under this R-10 foam was $114^{\circ} \mathrm{F}$ on August 15, 2009.

6. Connection details for minimizing air leakage. Minimizing air leakage should be of primary concern. Electrical wiring placement should be designed to stay as much as possible within interior walls. Electric chases are cut in the SIP foam prior to shipping, and when the panels are installed, $1-1 / 2$ in. diameter access holes must be made in plating, structural splines, and the precast foundation to align with electrical wire chases in the panels. The wall-foundation detail selected in Fig. 28 was done in part to help the electrical subcontractor run wires from the walkout lower level up into the exterior walls. From the walkout lower level, the electrician can easily measure the location of each vertical wire chase. All electrical wires are pulled after cutting out the outlet box locations and prior to setting electric boxes. The boxes are threaded onto the wires and set in the SIP. Apply low expanding foam sealant around the box and in the chase once all the wires are pulled to block this potential air leakage path.

When you position ceiling fans and other heavy lighting fixtures be sure the locations are clearly dimensioned on the drawings sent to the SIP manufacturer so they can provide added structural support and electric chases in the SIP ceiling panels. This was done for all the ceiling fans in ZEH5 as shown in the panel drawings in Figs. 18 and 19. With a little planning the desired location of these fixtures can be aligned with the panel splines and additional solid wood inserted in the panels in the factory. Along the ridge beam is also a good location to include a wire chase.
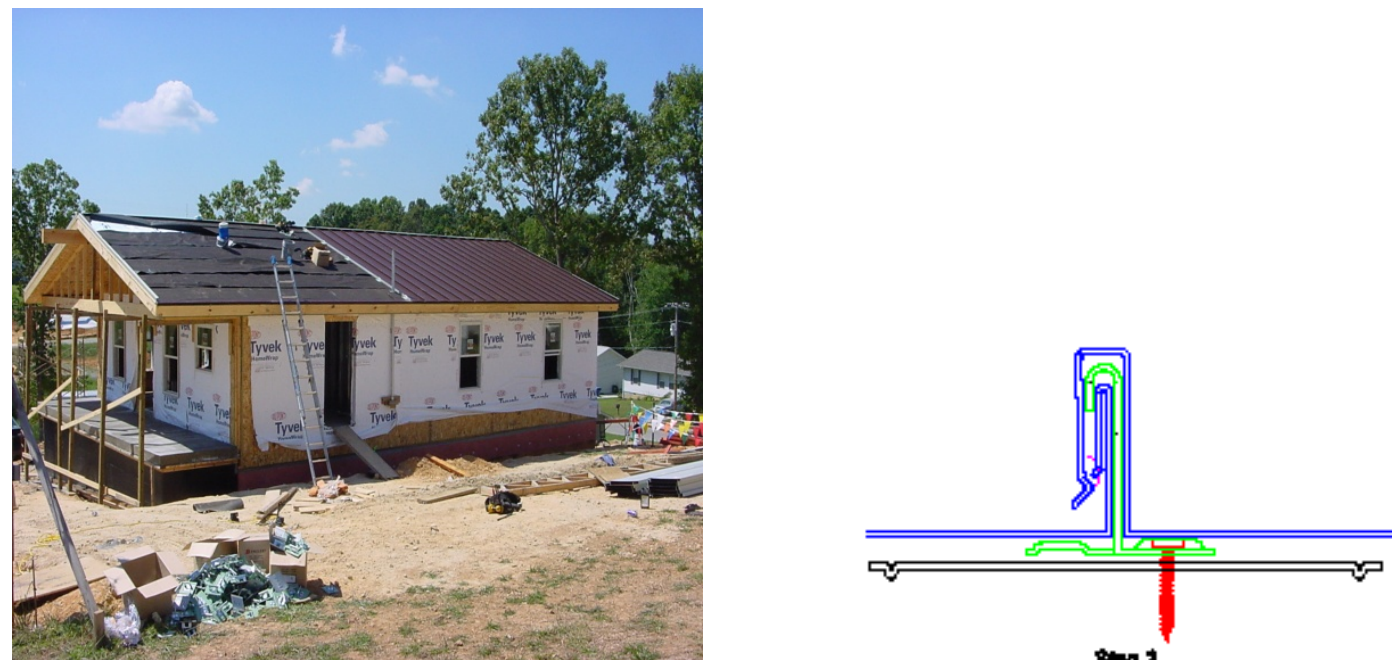

Fig. 30. Roof drainage plane under the raised metal roof. (See Appendix B, Resources.) 
The ridge detail is important to ensure air-tightness throughout the life of the structure. Manufacturers have different favorite details. The five test houses each have a different ridge detail. Established SIP manufacturers have been aware of the importance of ridge detailing for a long time. ZEH5 was taped with the peel-and-stick tape applied to the inside surface of all seams. If a heavy rain occurs when the panels are installed, or if the quality of the panel seam caulking and sealing is in anyway suspect, the seams should be taped.

Another common leakage point is where the exterior door dead bolts have been drilled into the door frames. Careful application of low expansion foam filling the space between the door frame and the rough opening will seal this up.

If the blower door test run before installation of the drywall on the wall and SIP ceiling indicates air leakage, the seams should be taped. The series of electrical chases and the panel seams create a three-dimensional matrix of potential passages for air to leak into and out of the SIP envelope. Experience with blower door studies prior to installation of the drywall on SIP wall and ceiling systems suggests that air leakage should never occur at any panel seams. There is always some leakage at electrical outlets. At $50 \mathrm{~Pa}$ suction, it is easy to see what is "typical" and what is "excessive" by simply running your hand over every outlet. Those that seem excessive can easily be sealed at the outlet box. At this point in the construction, the wires have been pulled and it is relatively easy to seal the outside of the electrical box while mounted in the SIP.

ZEH5 was blower-door-tested numerous times and was found to have a natural air change of 0.08 at $50 \mathrm{~Pa}$. The only taping prior to conducting the test was the 6 in. fresh air supply. However, when the motorized damper was closed, there was no detectable difference in whole-house airtightness measurements. The mechanical ventilation motorized damper is installed to open when not energized, so the HVAC system should be shut off and the fresh air inlet taped during the blower door test.

7. Check panel drawing accuracy. Roof panel span tables are available from the SIP manufacturer. The roof panels should not exceed the maximum allowable spans between the load points provided in the span tables. The Premier Industries website (see Appendix B, Resources. The spline detail is shown in Fig. 17. The thickness of the roof panel was $8 \frac{1}{2}$ in. The Premier Building Systems website includes a table (Table 4) for determining roof transverse loads that shows that a $14 \mathrm{ft}$ span from ridge to eave delivers a design load of $70 \mathrm{lb} / \mathrm{ft}^{2}$ for an $\mathrm{L} / 240$ deflection. In general, the entire exterior wall must be supported all the way to the foundation. The ridge beam usually has several intermittent load points that also must transfer the design load all the way to the ground. Understanding where these load points are located is important for maintaining the needed structural support within the conditioned space and the chase ways for HVAC, plumbing, and electrical distribution.

Avoid designs that call for ganged or mulled windows because they are heavy, awkward to handle, and harder to install. They also require more solid wood headers in the SIP in place of insulating foam, which has a much higher R-value. The floor plans for ZEH5 (Figs. 7 and 8) show all windows separated by at least $2 \mathrm{ft}$.

8. Attaching solar modules. The recommended roofing to cover an SIP roof structure and attach solar collectors is raised metal seam (Fig. 31, see

Appendix B for information on materials) with a reflectance of at least 0.3 in the mixed-humid climate. This is attainable with almost any color metal

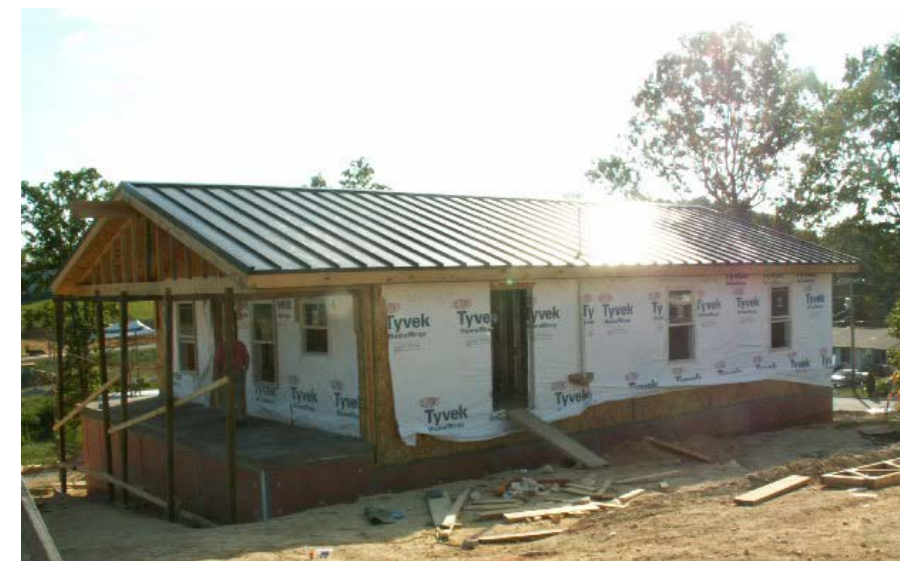

Fig. 31. Infrared selective coating was used on the brown raised metal seam roof to cover ZEH5. 
roof. The ZEH5 has a brown Englert S2000 Series with a reflectance of 0.31. This high reflectance for what appears to be a dark roof is due to the use of infrared-reflective pigments in the coating that selectively reflect most of the heat from the sun that comes in the infrared portion of the electromagnetic spectrum. The ZEH5 metal roof panels were sized, shaped and cut on site. Some effort was required to design the exact location of the raised seams so as not to interfere with the roof penetrations for the solar water heater pipes that needed to fall directly over an interior wall chase leading to the solar water tank in the walkout lower level utility room.

The standing seams on the roof allow for attachment of the solar water heater collectors and PV modules without any roof penetrations. This is advantageous because fewer roof membrane penetrations mean a lower risk for leaks. By using the S-5 clipping mechanism (www.unirac.com/s5.htm) shown in Fig. 32, the solar modules can be installed on the roof with no penetrations.

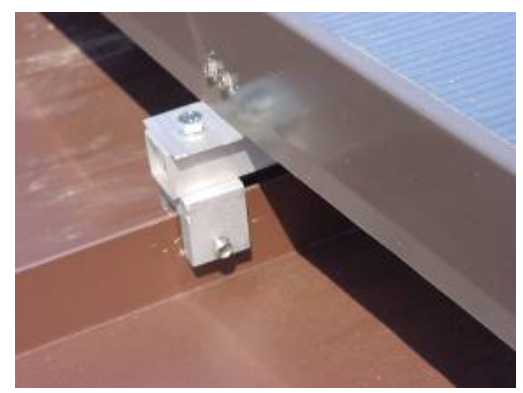

Fig. 32. S-5 mini clamp holding a solar module on ZEH5 to the raised metal seam.

9. SIP roof installation. The quickest way to get a simple SIP house closed up in a day is to stick with a single ridge beam and have it available on site to be lifted in place just as soon as the walls are up, plumbed, leveled, and squared. With a crane on site, a rigging plan should be developed for safety, for example, everybody wears a hard hat and everybody learns the standard signals for mobile cranes, particularly "stop" (Headley 2005).

Lifting the ridge beam in place with a boom truck is the best method. Use a riggers sling made up of double choker hitches. Have the roof panels and crews in place so that once the crane arrives and the beam is placed, the roof panel placement can commence immediately for reduced rigging time and cost.

A two-person crew should be set up on the ground rigging and sealing up the edges of the roof panels with a second two-person crew installing the panels. The I-joist splines in the ZEH5 roof panels were factory installed on one edge of each panel.

Figure 33 shows the SIP roof panels being installed on ZEH5. A string is run from gable to gable to line up the ridge as is done in setting conventional trusses. Stop-blocking installed on the bottom side of the panel a distance equal to the overhang and the thickness of the wall provides a rough stop to get the panel dropped close to the string. By not fastening

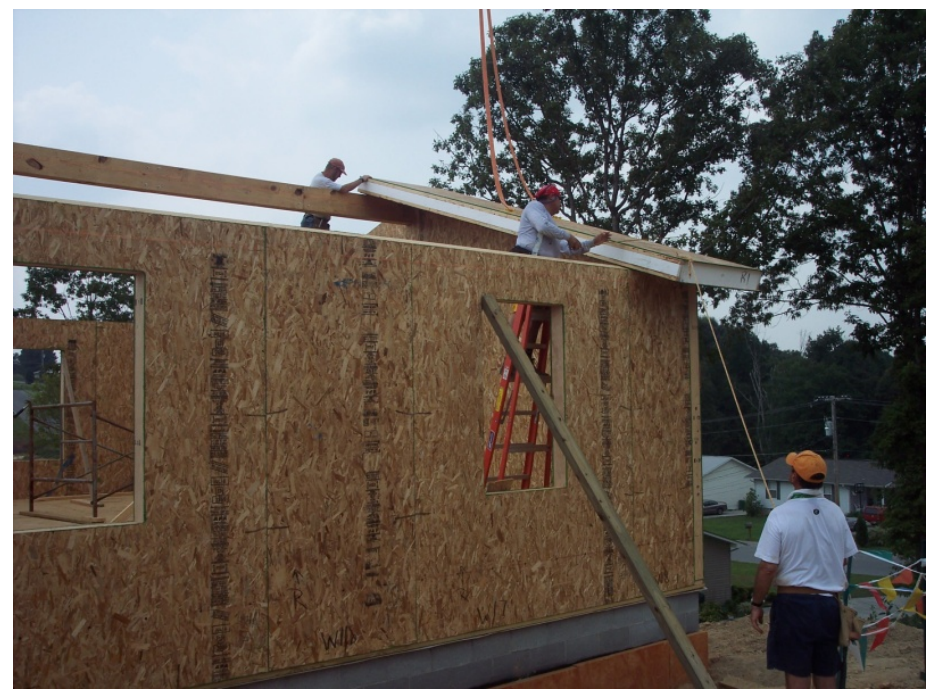

Fig. 33. The SIP roof panel installation. down the leading edge of the ceiling panels until the next panel is in place, the workers are able to fit the panels together smoothly. Aligning the panels and tightening each joint goes quickly and safely with the right work plan and good teamwork. If the roof pitch is steeper than the roof crew is comfortable walking on, walk boards can be installed on the top side of the panels for safety. Roof panel installation can be alternated with one on each side of the ridge to keep the roof forces balanced during construction. 
10. Planning. Lastly and most importantly, it is important to have a good plan that matches the resources available. This cannot be completely articulated without many site-specific variables, but a good plan will include the following:

1. Taking the time to meet with all the subcontractors and key personnel. This will make a better whole building.

2. Know the location of structural point loads.

3. Continuously check the accuracy of shop drawings and verify that the installation matches the intent of the plans.

4. Ensure that window and door rough openings are correct and that the HVAC chases are specified and maintained as construction proceeds.

5. Ensure the electrical plan is complete and reflected in the panel cut drawings sent for approval prior to panel fabrication.

6. Keep all plumbing out of exterior walls and keep the electrical in exterior walls to the bare minimum.

7. Run all vertical chases into floor spaces by routing from exterior to interior walls and then up or down.

Finally, an excellent book to read before designing and constructing your first SIP house is Building with Structural Insulated Panels (Morley, 2000).

\subsection{WINDOWS}

For the mixed-humid climate, with all-electric houses and energy costs around $\$ 0.10 / \mathrm{kWh}$, it is recommended that the National Fenestration Rating Council R-value be at least 0.34 . The solar heat gain coefficient should be no higher than 0.33 . The visible transmittance for the windows used on the five test houses was 0.51 . The warranty on the test house windows is not prorated and covers glass for 20 years and nonglass parts for 10 years. The specific vinyl-clad wood windows specified for the test houses were Andersen 200 Series tilt-wash, double-hung, low-E, model numbers 244DH3030 and 244DH3050 (www.andersenwindows.com). The ten-window package for ZEH5 was estimated to cost about $\$ 2900$ from a local window distributor in 2005. In September 2008 all the double-pane insulated glass packs were replaced with Serious Materials triple layer windows with a lower U-value 0.14 and SHGC 0.27 . The EnergyGauge model suggested that this saved $220 \mathrm{kWh}(5 \mathrm{kWh}$ in the cooling season and $215 \mathrm{kWh}$ in the heating season). This amounts to a $\$ 22 / \mathrm{yr}$ savings assuming $\$ 0.10 / \mathrm{kWh}$. An important side benefit of the triple layer window is the increased sound attenuation.

If installing interior window trim, specify jamb extensions. This will speed the onsite window installation. The rough openings required for the two window sizes used are exactly $3 \mathrm{ft} \times 3 \mathrm{ft}$ and $3 \mathrm{ft} \times 5 \mathrm{ft}$. Before the house wrap is installed, all window and door rough openings in the SIP should be inspected. They are commonly made with a router and are rounded, and may need to be squared off before the house wrap is installed for tight-fitting windows and doors. The windows are installed after the house wrap as outlined below:

1. The rough opening, which is covered by the house-wrap, is cut out and except for the top, folded into the window buck after ensuring that the rough opening will permit plumb, level, and square window installation. The top flap is folded up and out of the way until the window is installed.

2. The opening is panned with DuPont FlexWrap (see Fig. 29). 
3. A continuous bead of caulk is applied to the house wrap on the outside wall around the rough opening on the sides and across the top, not the bottom.

4. A flanged window is installed.

5. The window is centered in the opening and shimmed, with close attention paid to the middle part of the window frame. With drywall returns windows must be shimmed to maintain a uniform reveal.

6. The window is leveled and secured through the flange.

7. Jamb flashings on both sides are installed to cover the entire window flange. DuPont StraightFlash (www.tyvek.com) for all test house jambs and headers.

8. Header flashing is installed covering the entire mounting flange and is extended beyond the outside edges of both jamb flashings.

9. The taped-up house wrap above the window is folded back over the taped flange above the window and tape.

10. The interior between window and wall framing on all four sides is insulated and air-sealed with low-pressure expansion foam or backer rod and caulk.

\subsection{SIP ROOF AND CEILING}

For an affordable high performance house in the mixed-humid climate, a SIP with thickness of at least $105 / 16 \mathrm{in}$. and $0.95 \mathrm{lb} / \mathrm{ft}^{2}$ XPS core foam and 7/16 in. OSB facers are recommended for the roof. A ridge beam is suggested because it is easier to air seal the ridge. An extended overhang of $2 \mathrm{ft}$ on the eaves helps control the solar gain on the south façade in the summer.

The roof and wall panels should be certified by the manufacturer in accordance with:

1. Structural codes, ASTM E72 for transverse load, axial compressive load, racking shear and header loading, ASTM E695 impact testing, ASTM E1803 cold creep.

2. Fire testing with approved finishes (minimum 15 min thermal barrier such as $1 / 2$-in. drywall or $1 \times$ wood paneling) shall have passed ASTM E-119 $1 \mathrm{~h}$ fire-resistant wall assembly, UBC 263 corner room test.

Prior to ordering the SIP, design loads must be provided: roof transverse loads (live, dead, calculation of the wind load, and total); wind loads (basic wind speed, design wind loads for walls and roof uplift); and seismic design category. The weight of the solar collectors for the PV and solar water heater must be included in the dead load calculation, and tripling the weight of the solar collectors (or increasing to whatever extra amount of collectors could still fit on the south facing roof area) should be considered to allow the house to attain as high an energy efficiency as possible. If seismic hold-downs are required, special preplanning is necessary.

The ZEH5 ridge beam was sized to be supported by the posts embedded in the gable wall and two intermediate locations carrying the load down to a spread-footer.

The roof transverse load must be less than the allowable load as provided by the SIP manufacturer that used ASTM E72. ASTM E72, section 11 is a span test that uniformly loads the panel to the point of failure. ZEH5 has a $14 \mathrm{ft}$ span horizontally from the eave to the ridge. Pounds per square foot measured at failure must be recorded and divided by a safety factor of 3 to determine allowable load. Before the roof fails, it will deflect; therefore, when the span tables are generated, they are presented as a function of the allowable deflection of the panel. The deflection is measured by taking the horizontal length (L) of the roof span and dividing by a deflection factor of 240 . This means that in ZEH5, the roof, when fully loaded, will not deflect more than 14/240 or about 11/16 in. 
The ZEH5 roof used $4 \mathrm{ft}$ wide panels the full length from ridge to the end of the eave and engineered I-joist splines as shown in Figs. 17 and 18.

A roof with a ridge beam should be assembled with the roof panels placed in opposition, one on each side of the ridge, working down from gable to gable. The roof should be covered as quickly as possible with \#30 asphalt-impregnated roofing paper (ASTM 4869 Type II). Before being covered with roofing paper seal, covering the panel joints with asphalt cement helps prevent the OSB skins from absorbing moisture and swelling. Extra strips of underlayment can be laid over the patch to keep the tar from melting in and running down slope. If the SIP roof does get wet, it must have time to dry before being covered. The preferred roofing system is raised metal seam with a space between the metal roof and the building paper to serve as a drainage plane. 



\section{SPACE CONDITIONING EQUIPMENT}

\subsection{SIZING}

A ZEH in mixed-humid climates is well suited for heat pumps, either high efficiency split air source or geothermal. A DC commutating fan motor should be used to meet the ASHRAE Standard 62.2 for ventilation air requirements using low fan power.

The suggestions provided here are based on data from the test houses described in this report. Table 12 highlights the equipment used in ZEH5. Heating and cooling design loads were calculated using Manual J (eighth edition) for the whole $\left(2632 \mathrm{ft}^{2}\right.$ ) house, which includes conditioning the walkout lower level (Rutkowski 2004). The breakdowns for the heating and cooling design loads are shown in Table 12. The HVAC was sized for the entire house both upstairs and downstairs. These loads were cross-checked with the EnergyGauge computer model for this EnergyGauge version 2.6.06-09/-4/2007 (FSEC 2006).

Table 12. Heating and cooling design load breakdowns for ZEH5, calculated using Manual J

\begin{tabular}{|c|c|c|}
\hline & $\begin{array}{l}\text { Heating heat loss } \\
\text { (Btu/h) }\end{array}$ & $\begin{array}{c}\text { Cooling sensible gain } \\
\text { (Btu/h) }\end{array}$ \\
\hline Vertical glass & 3641 & 3404 \\
\hline Doors & 1761 & 898 \\
\hline Above-grade wall & 4946 & 0 \\
\hline Below-grade wall & 1995 & 1429 \\
\hline Ceiling & 2952 & 0 \\
\hline Floor & 119 & 246 \\
\hline Infiltration & 4124 & 7573 \\
\hline Duct & 0 & 0 \\
\hline Ventilation & 2177 & 640 \\
\hline Blower heat & 0 & 685 \\
\hline Latent heat & 0 & 3701 \\
\hline Totals & 21,716 & 18,575 \\
\hline
\end{tabular}

\subsection{GEOTHERMAL HEAT PUMPS}

ZEH5 used a 2 ton WaterFurnace E-Series unit (model \# W024TR111/NBDSSA), with an electronically commutated motor (ECM) blower and R-410A refrigerant (www.waterfurnace.com). The unit was sized to match the Manual $\mathrm{J}$ load for the entire house of $2632 \mathrm{ft}^{2}$. The design heating load was $21,716 \mathrm{Btu} / \mathrm{h}$, and the design sensible cooling load was $18,575 \mathrm{Btu} / \mathrm{h}$. The estimated COP at peak was assumed to be $3.7 \mathrm{Btu} \mathrm{h} / \mathrm{W}$ and the EER, $15.5 \mathrm{Btu} \mathrm{h} / \mathrm{W}$ (cooling capacity at $95^{\circ} \mathrm{F} /$ input energy). This heat pump came equipped to help heat domestic hot water with an on-board, factoryinstalled desuperheater and pump. However, this house was equipped with a solar water heater.

The ground loop was experimental at the time. It is important to note that the method used for this experiment is not "International Ground Source Heat Pump Association (IGSHPA) certified." The horizontal loop was placed completely within the trenches dug around the house for other purposes during construction. The high density polyethylene pipes are filled with an environmentally friendly antifreeze/water solution that acts as a heat exchanger. In the winter, the fluid in the pipes extracts heat from the earth and carries it into the house. In the summer, the system reverses and takes heat from the house and deposits it to the ground. Figure 34 shows where $1500 \mathrm{ft}$ of $3 / 4$-in. pipe is installed, in a six-pipe $244 \mathrm{ft}$ trench made up by: 
- $109 \mathrm{ft}$ of walkout lower level foundation over cut,

- $63 \mathrm{ft}$ of water trench dug $3 \mathrm{ft}$ deeper to keep the heat exchanger pipe away from the water line to avoid freezing of potable water pipes in the winter and heating of incoming cold water in the summer,

- $50 \mathrm{ft}$ of sewer line trench running from the street to the outlet on the south side of the foundation, and

- $22 \mathrm{ft}$ of footer drain trench run out to daylight on the southwest corner of the foundation.

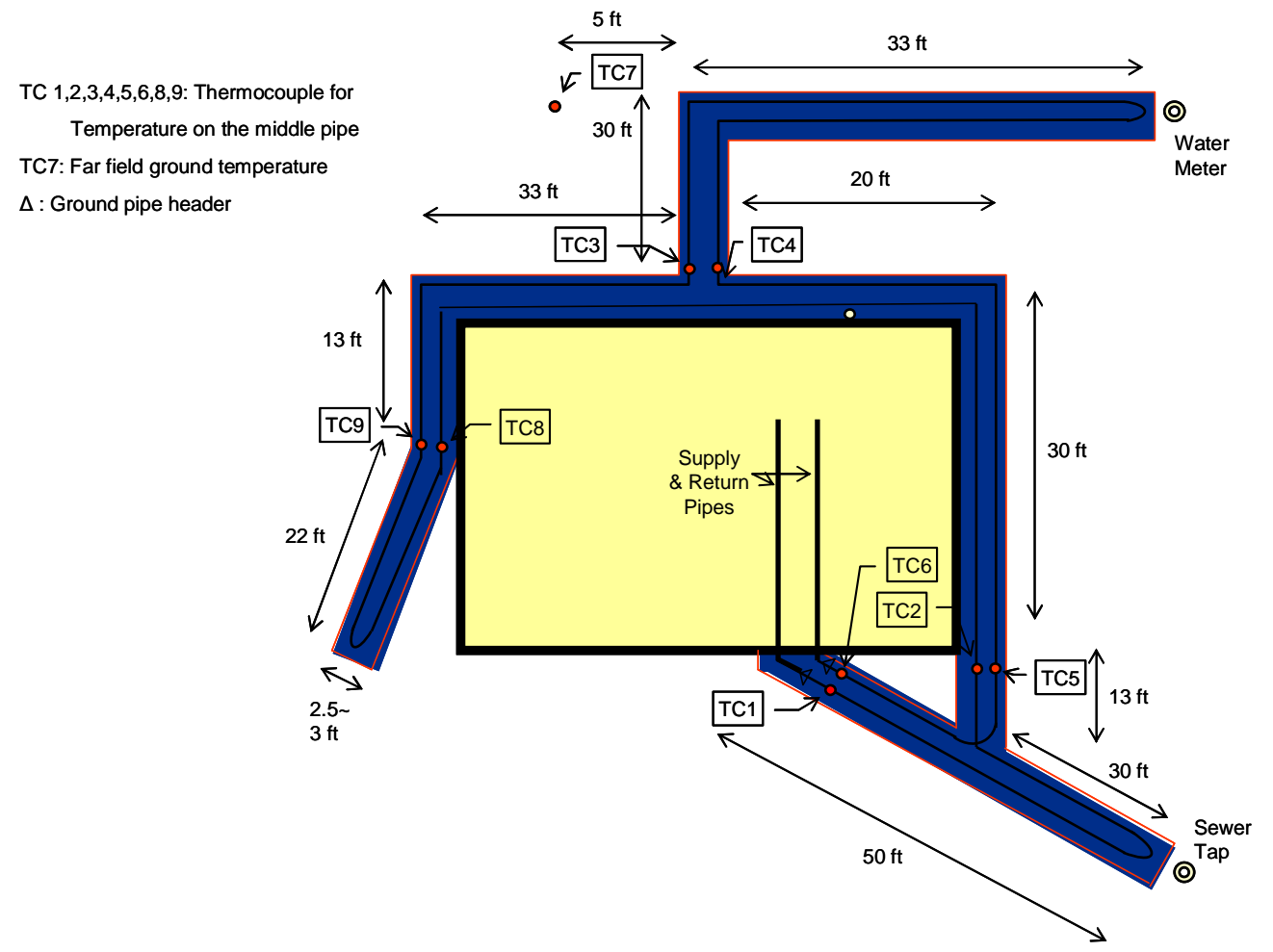

Fig. 34. Locations and lengths along trenches where ground heat exchanger pipe was installed around the ZEH5 foundation.

Three loops of about $500 \mathrm{ft}$ each were run out and back in the full $244 \mathrm{ft}$ of available trench. The length of the loop was determined by WaterFurnace using an in-house program and some engineering judgment. This was an identified need to develop an accurate loop design tool that also takes into account the impact of the heat gain and loss from the below-grade walkout lower level walls and the close proximity to the sewer run-out. In 2008, DOE funded ORNL to develop a more detailed model for ultimate sizing and certification of these types of loop installations. The three loops are "headered" up to a single 1.5 in. inlet and outlet high density polyethylene pipe on the south side and run into the equipment room in a trench under the walkout lower level slab. The inlet and outlet pipes are connected to the circulating pump in the bottom-floor ZEHcor wall near the vertical WaterFurnace unit. No additional excavation was required. Two PVC conduits must be provided in the foundation drawings and with confirmation of placement before the footers are poured and/or the foundation wall is installed in line with the geothermal loop header and the placement of the ZEHcor wall, geothermal unit, and circulating pump location.

The $3 / 4$ in. diameter pipe was selected partly because it was much easier to install the turn-arounds at the end of each ditch to complete the loop without having to cut and install elbows. The header is buried about $4 \mathrm{ft}$ deep and $8 \mathrm{ft}$ from the south side of the house. The location needs to be well documented and kept in the user manual for the house. Accidental damage while landscaping or 
making other exterior additions like decks and sun rooms are a common cause of horizontal loop damage. The fact that more than half of the loop is located under other buried service pipes enhances the long-term durability of the ground loop. Many locations now have "one call" services that alert all conventional utilities in the area that the homeowner is planning to excavate the site; utilities will mark the location of their utility lines free of charge.

The common trenching of utilities is frequently used in commercial buildings and does require careful communication and integration during construction between the general contractor, trades, and code inspectors. The construction supervisor must ensure the excavation subcontractor understands that the width and depth of the common utility trenches need to be slightly deeper and potentially a bit wider. This is handled in high performance house construction by major trade statements of work and checklists for job ready and job completion quality assurance programs. Proper staging in the correct order must be clearly communicated. For example, the water trench must be dug, followed by the six-pipe geothermal coil installation, pressure checking the loop for leaks, partial backfilling to proper depth for the water line placement (space at least $3 \mathrm{ft}$ from the nearest geothermal loop and far enough below grade to meet code for freeze protection), and finally, backfilling to grade.

The standard practice of installing horizontal ground heat exchangers is intended to keep the pipe at least $10 \mathrm{ft}$ away from the building foundation footer to avoid freezing the ground and potentially causing foundation structural problems. Since the foundation system is insulated on the outside wall surface with $23 / 8 \mathrm{in}$., $6 \mathrm{lb} / \mathrm{ft}^{3}$ fiberglass drainage board, and both external and internal footer drains run to daylight, the soil moisture content should stay near saturation levels, and only minimum soil freezing and no foundation structure freezing is likely in the mixed humid climate. Even if the ground near the footer and surrounding the geothermal pipe should freeze, the insulation board would serve as a slip plane and compression cushion between the expansion and potential uplift of frozen soil. The insulation on the outside of the structural foundation wall keeps the temperature near inside conditions. Even with no added heat in 2006, the walk out lower level was always above $60^{\circ} \mathrm{F}$. Added protection is provided by the WaterFurnace unit itself, which has a lockout whenever the water circulation loop temperature drops below $15^{\circ} \mathrm{F}$. Heat load at that point is met by the electric resistance backup heaters. The lowest entering water temperature measured on the loop surrounding ZEH5 was $42^{\circ} \mathrm{F}$ in February 2009.

The sewer runout is also separated from the six-pipe system to minimize the risk of freezing waste water; however, it was theorized that in winter, warm waste water heat would be partially recovered, and in late summer, waste water flow would actually help cool the soil and carry away reject heat from the house. Figure 35 shows the three-loop, six-pipe ground heat exchanger being installed in the sewer trench to the street.

During the winter of 2007-2008, the space heating load of the entire $2632 \mathrm{ft}^{2}$ of conditioned space was easily met by the geothermal heat pump with very minimal supplementary heat and with no reduction in soil temperature next to the ground coils as measured against a reference in a far-field thermocouple buried at the same average depth (about $5 \mathrm{ft}$ ) as the six-pipe loop. The cost to install the loop, test for leaks, purge, charge, and commission the unit was $\$ 2000$. It took 16 person-hours to install the loop and 8 person-hours to commission the unit. The rule of thumb at the time the installation was performed, in August 2005, was that loops are installed and units commissioned for $\$ 1000 /$ ton. The pipe cost is

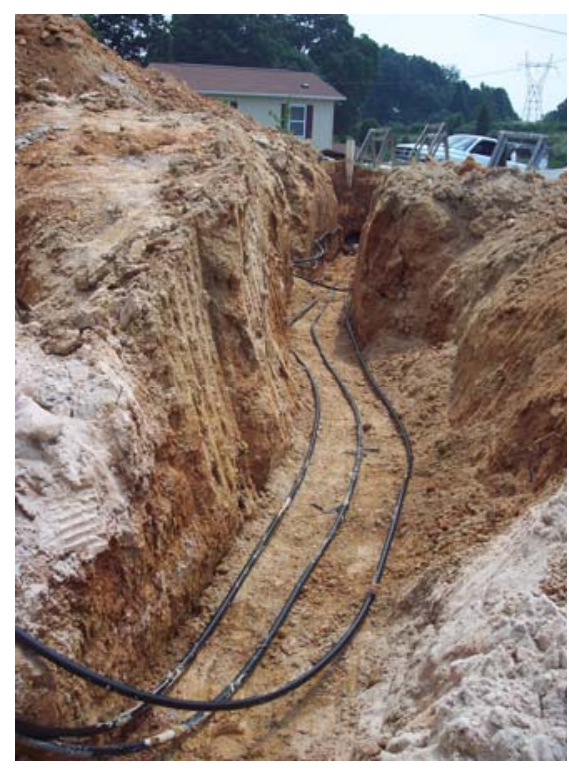

Fig. 35. Ground loop being installed in the bottom of the sewer pipe trench. 
estimated at $\$ 250 /$ ton, installation labor at $\$ 750 /$ ton. The heat pump is a packaged water-to-air unit that is factory charged with refrigerant, avoiding the problems and higher costs associated with fieldcharged split systems. The underground high-density polyethylene piping is usually guaranteed for 50 years. The ASHRAE equipment handbook lists the median service life of a water source heat pump as 4 years longer than that of an air source heat pump.

The geothermal system should be installed by a certified installer. The IGSHPA is a non-profit, member-driven organization that offers both design and installation training. Thermal fusion fittings were used to connect all pipe sections. Thermal fusion connections are either socket- or butt-fused to form a joint stronger than the original pipe. A fusing iron that heats up to $\sim 550^{\circ} \mathrm{F}$ is used to melt the pipe to each fitting. Before backfilling, the loop should be pressure tested with water or air to ensure there are no leaks. Generally this is at 60 psi for a minimum of 20 min. See Appendix B for geothermal information and material resources.

\subsection{DUCTS}

The central location of the blower equipment with respect to the floor plan allows short and simple duct runs. In the two-story model of ZEH5, all the ducts and HVAC equipment are in the conditioned space. The location of the supply ducts serving the top floor are fully within the insulated cathedral ceiling above the dropped ceiling. The area available for locating the ducts and indoor fan unit above the dropped ceiling in ZEH5 is shown in the shaded area in Fig. 36. The ducts are shown in this conditioned chase in Fig. 37. A separate trunk with 4 supply registers serves the walkout lower level. Two returns are used-one for upstairs and one for downstairs, each located at floor level.

The ducts were sized using Manual D (ACCA 2006). The measured air flow in cfm for each room is shown in Fig. 38. The needed cfm for each room comes from the Manual J (ACCA 2006) room-byroom load calculation. The main supply trunk should be hard-piped, sealed with mastic, and insulated on the floor, and lifted into place. Insulated ducts mitigate condensation risk. Short flex duct runs are used to connect the main supply trunk with high wall supply registers in every room except the laundry and the bathrooms.

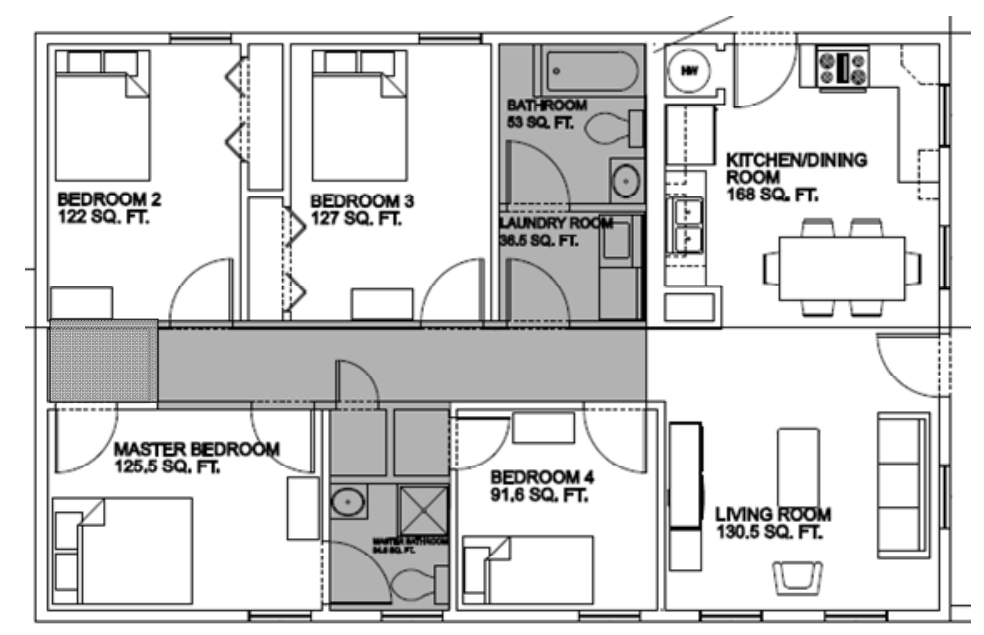

Fig. 36. The shaded area marks where the ceiling is dropped to accommodate the HVAC system. 


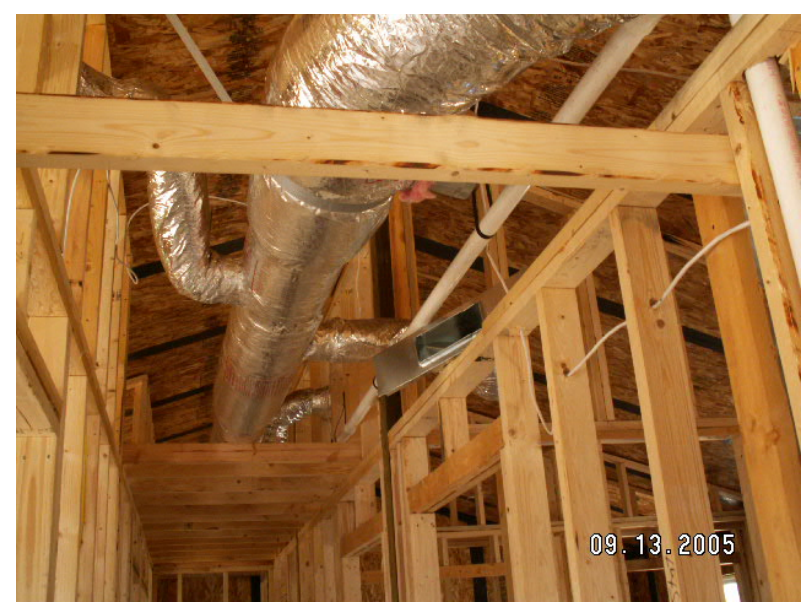

Fig. 37. Supply ducts located in the conditioned chase formed by the ceiling SIP and dropped ceiling.

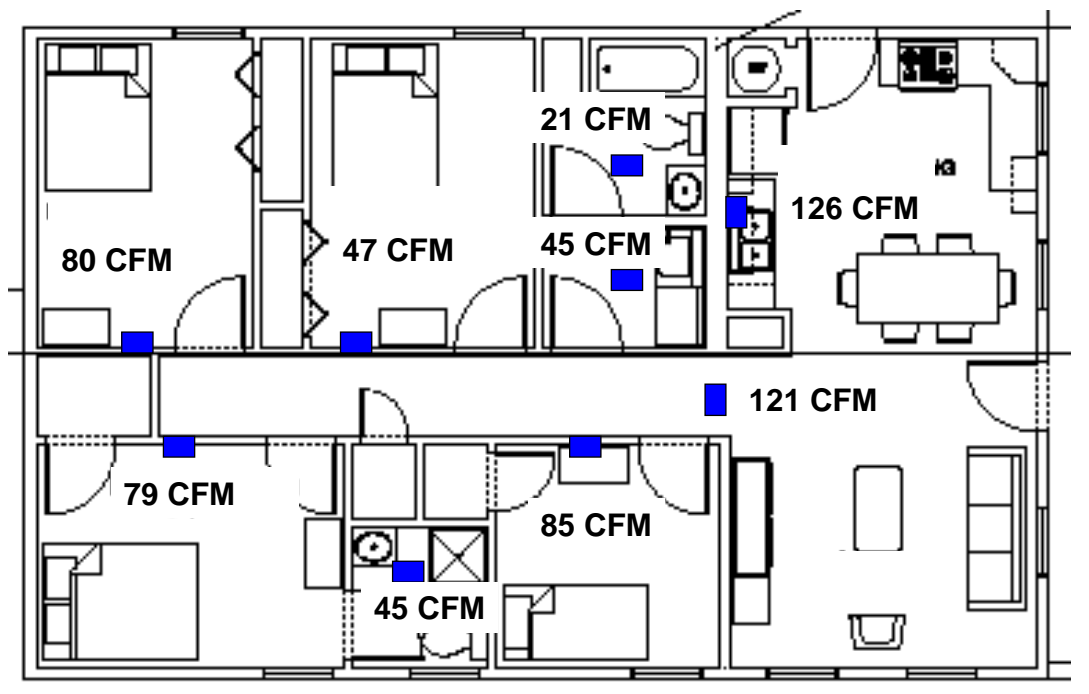

Fig. 38. Measured air supply cfm delivered to each room in ZEH5 and location of each high sidewall register (solid blue rectangles).

Transfer grills are used in each of the bedrooms with high registers on the interior wall nearest the central hallway, inside the room and low in the hallway. When an internal wall chase is not available, jump ducts should be used to minimize pressurizing the bedrooms and depressurizing other areas of the house when the circulating fan is running and bedroom doors closed. Keeping minimum pressure differences from room to room and from inside to outside helps control unintentional air flow and minimizes unwanted air and moisture exchange through the building envelope. A single central return is positioned on the floor in the central hallway nearest the front door. A low-resistance return path between every room and the return is maintained by transfer grills and jump ducts. In general low return systems are used in all five test houses.

High sidewall supply outlets discharge air parallel to the ceiling toward the outside walls. Figure 39 shows the measured air flows delivering thermal comfort to this space for the 1 year measurement period from January 1, 2007, to December 31, 2007. The correctly sized outlets' discharge pattern extends to the opposite wall, and high-velocity air will not drop into the occupied zone. Sidewall outlets perform best during cooling mode, so they are more suitable for homes located 
in warm climates. The high cathedral ceilings provide an ideal mixing zone for secondary air exchanges between the supply air momentum and the room air. This enables the jet of supply discharge air to entrain a large amount of room air as it develops into a secondary air pattern. Figure 40 shows the thermal comfort conditions were about the same during the 6-9 person occupancy period from November 1, 2008, and October 31, 2009.

\subsection{VENTILATION AIR TREATMENT}

ZEH5 has a 6 in. fresh-air supply duct running from the north side of the house, through the ZEHcor wall, to the return side of the blower. A manual damper and a motorized damper control the amount of ventilation air. The AirCycler (www.Aircycler.com) is used to monitor the heat pump compressor. For at least 10 min every half hour the motorized damper is opened, and when the compressor is not needed to condition the space, the AirCycler turns on the HVAC central ECM fan at low speed and brings in a prescribed amount of fresh air. The design was to meet the current version of ASHRAE 62.2, which in the case of the ZEH5, is $63.7 \mathrm{cfm}$ for the four-bedroom residence. The AirCycler is wired to also signal a relay that energizes the upstairs bathroom exhaust fan to help balance the house air pressure and ensure adequate ventilation air for indoor air quality and moisture control.

Figure 39 shows that the HVAC system provided good thermal comfort in ZEH5 from January to December 2007, as measured by the hourly average interior temperatures and relative humidity on both floors. The sensors were located $2 \mathrm{ft}$ above the thermostat in the central hallway on the upper level and about the same height off the floor on the walkout level. Figure 40 shows the thermal comfort conditions from November 1, 2009 until October 31, 2009. This is the period in which the family of 6 was living in ZEH5. The HVAC system kept the house within generally acceptable comfort conditions except for the relative humidity in the summer of 2009. Once the daytime thermostat was set at $76^{\circ} \mathrm{F}$, the family confirmed on numerous occasions that they were not uncomfortable.

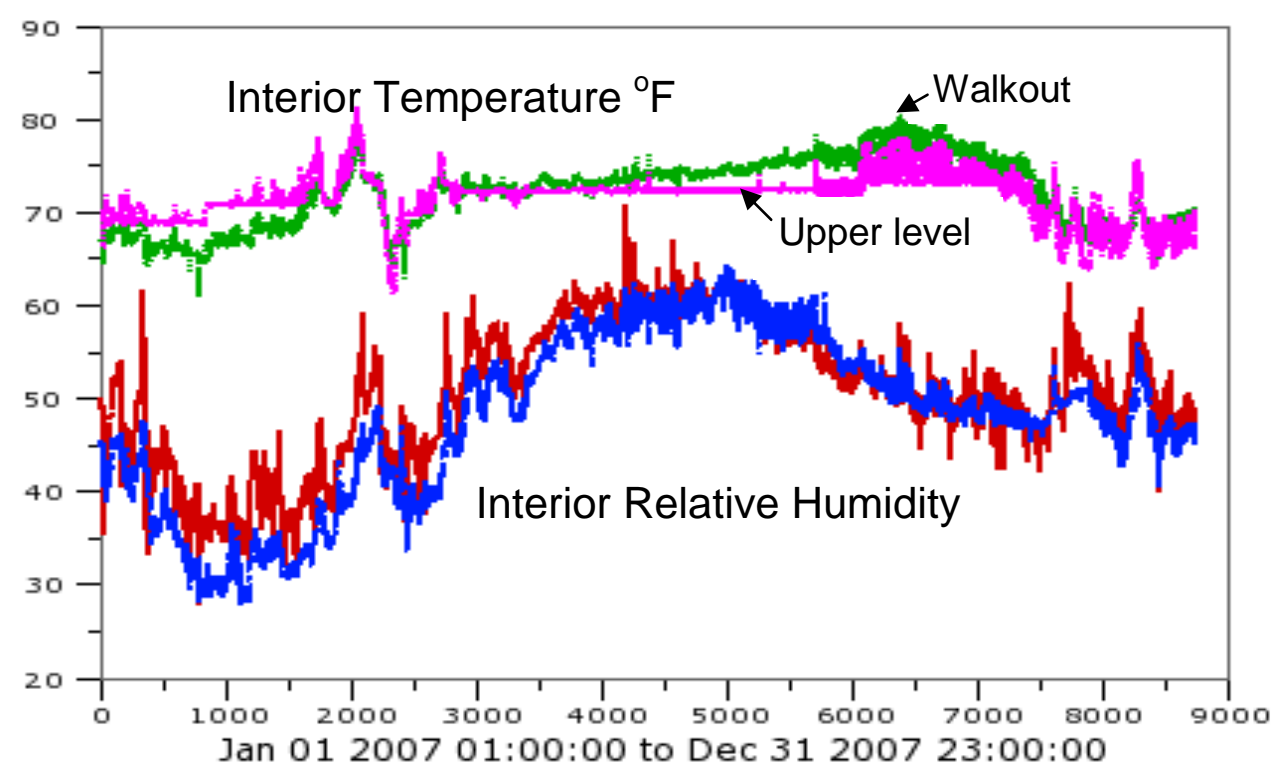

Hours of the year

Fig. 39. Measured 2007 interior temperature and relative humidity. 


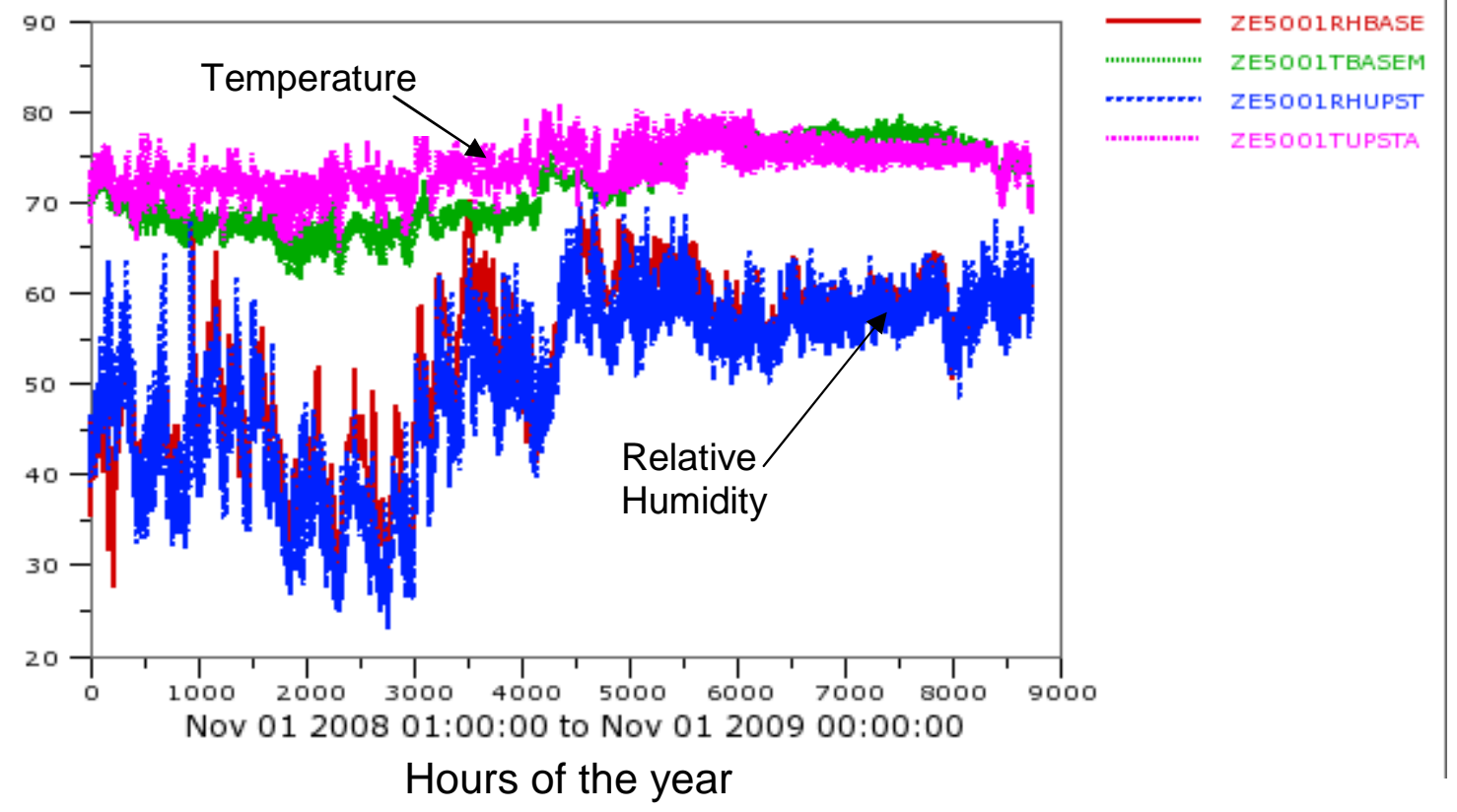

Fig. 40. Measured hourly temperatures and relative humidity of the interior space from November 2008 to October 31, 2009.

The Manual J (ACCA 2006) calculations for conditioning the $2632 \mathrm{ft}^{2}$ of ZEH5 provided good guidance for selecting a 2 ton unit for space conditioning (1300 $\mathrm{ft}^{2}$ per ton). 



\section{ELECTRICAL}

\subsection{WIRING}

Electric wire chases should be used to the minimum extent possible in exterior walls. Chair railing and base molding can be built out slightly to form wire chases and can enhance the interior décor. In both SIP and stick construction, electric outlets are always a major residual leak risk even after dedicated effort at creating an airtight envelope. In ZEH5, the space available above the ridge beam was used as a wiring chase to reach the ceiling fixtures. After the wiring is complete, this space is completely foamed (see Figs. 41-43).

Electrical crew complaints on the construction of ZEH4 prompted a change in the construction plan for ZEH5. Vertical wiring chases were cut into the panels every $4 \mathrm{ft}$ starting $2 \mathrm{ft}$ in from each vertical seam, allowing the electricians to run wires more easily from the walkout lower level into the above-grade exterior walls. Figure 44 shows how the panel does not sit on top of the floor, but rather at the same level as the 20 in. floor trusses, giving plenty of access for fishing wire.

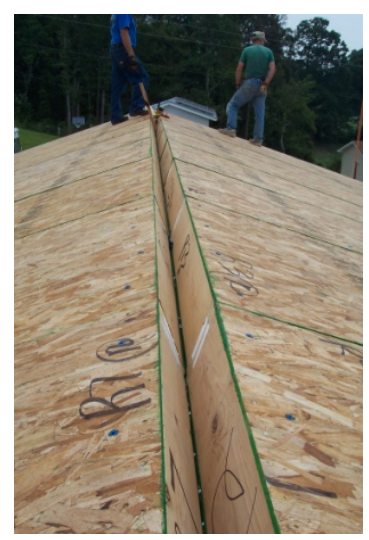

Fig. 41. Space above the ridge beam is used for a wiring chase.

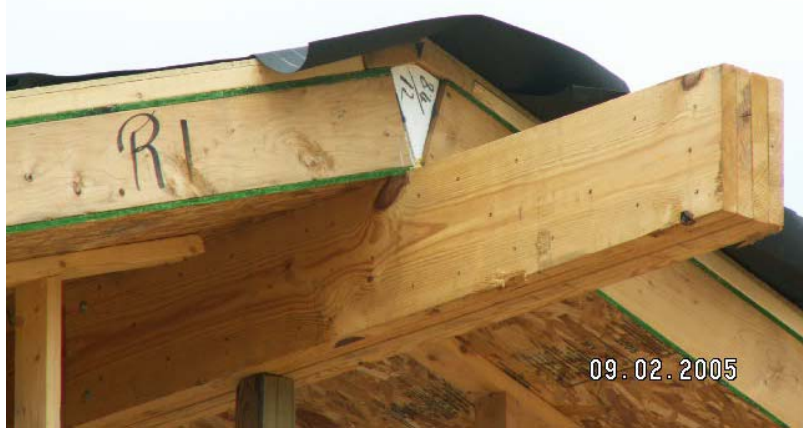

Fig. 43. A wedge of foam is provided by the SIP manufacturer to fill the space at the ridge.

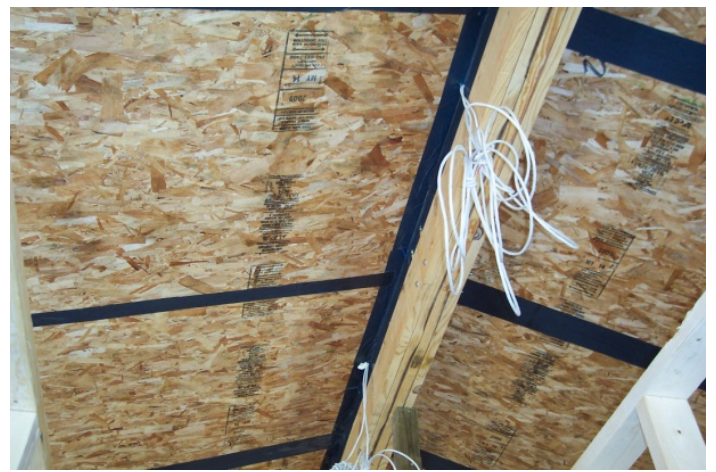

Fig. 42. Wires being pulled into the space above the ridge beam.

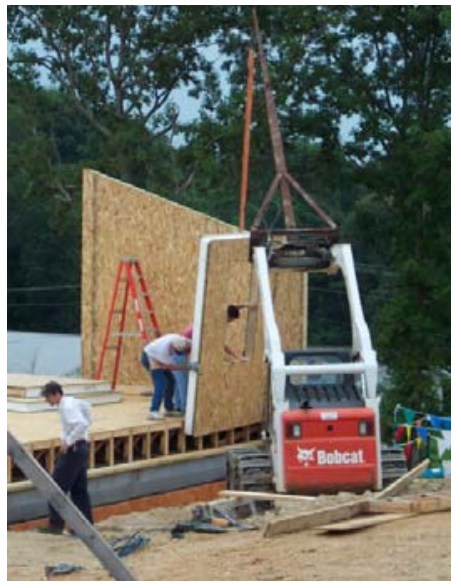

Fig. 44. Mounting the wall panels on the side of the floor trusses leaves easy access to run electric wires from the walkout lower level into the vertical wiring chases in the wall SIP. 


\subsection{CEILING FANS}

The location of ceiling fans and heavy ceiling light fixtures should be clearly marked on drawings sent to the SIP manufacturers, who can easily accommodate for the added pullout strength needed for ceiling fans, as well as the location of all embedded wiring chases. Look for Energy Star ratings on all ceiling fans.

\subsection{LIGHTING}

The goal is to install all florescent lighting and LEDs as they become available and affordable. Some ceiling fans more easily accommodate a compact fluorescent light than others. Consider using either globe or sconce lighting packages. Under- and above-cabinet fluorescents in the kitchen work very well. Wall sconces work well with compact fluorescents, as shown in Fig. 45. In ZEH5, fluorescent bulbs were used throughout the house even around the bathroom mirrors. These bulbs are now reasonably priced, and LED bulbs with even better lumens/watt than fluorescents are expected to be available as early as 2010 at the time of this writing. A good source for selecting lighting is the Energy Star Advanced Lighting Package specification listed in Appendix B, Resources.

\subsection{PV SYSTEMS}

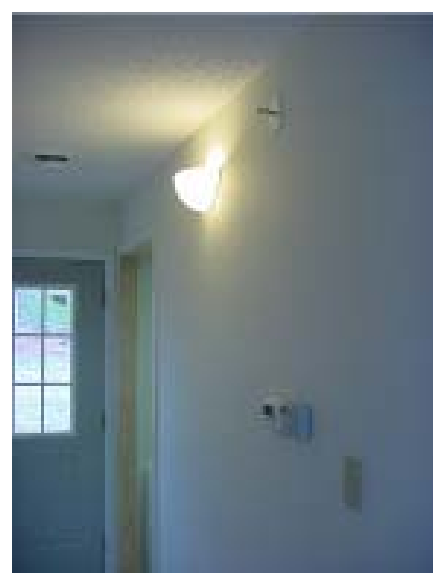

Fig. 45. Sconces with compact fluorescents.

TVA's Green Power Switch Program pays homeowners $\$ 0.12 / \mathrm{kWh}$ above the current residential rate for all the AC solar power generated in a grid-tied arrangement. Figure 46 is a schematic of TVA's required method of tying the PV system to the grid. All interconnected equipment must be Underwriters Laboratories (UL)-listed to the appropriate UL standards for terrestrial power systems. The system must have a lockable disconnect device accessible outside the house and a standard watt-

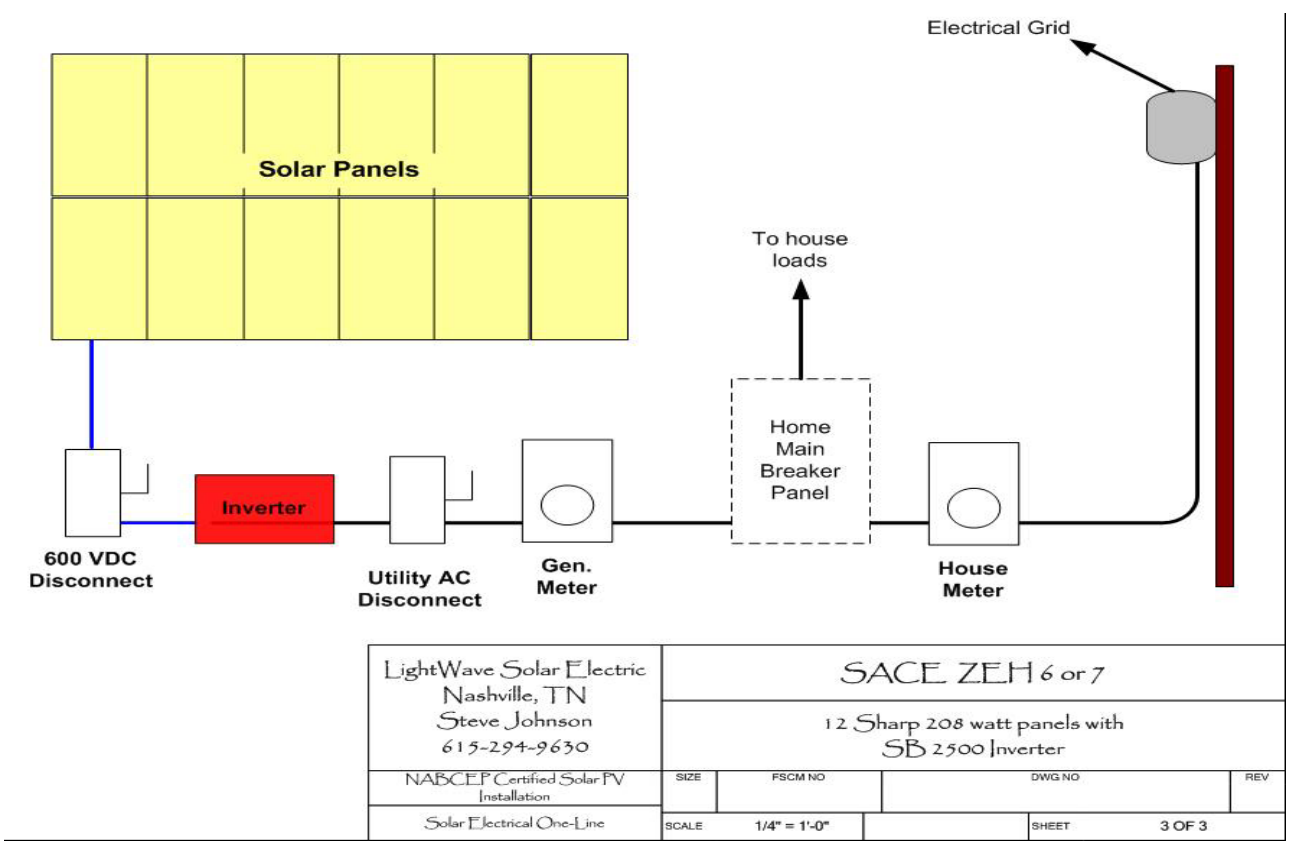

Fig. 46. Arrangement TVA requires for tying solar systems to the grid. 
hour meter to measure the AC output of the generation system located at the same level and within $1 \mathrm{ft}$ of the billing meter. The systems must be installed in full compliance with all requirements of the latest edition of the National Electrical Code (ANSI/NFPA-70). The PV system designed for ZEH5 is described below.

\subsubsection{PV System Designed for ZEH5}

Twelve $208 \mathrm{~W}$ polycrystalline PV modules configured for $48 \mathrm{~V}$ and interfaced with a GridPoint platform were installed in June 2008. Above the dropped ceiling a DC-rated combiner panelwas installed. All associated wiring, hardware, and electrical components to configure for the Outback MX60 Charge controller in the GridPoint unit were also installed. The combiner is located in the laundry room with easy acess via an attic hatch. A schematic showing the actual PV installation is shown in Fig. 47.

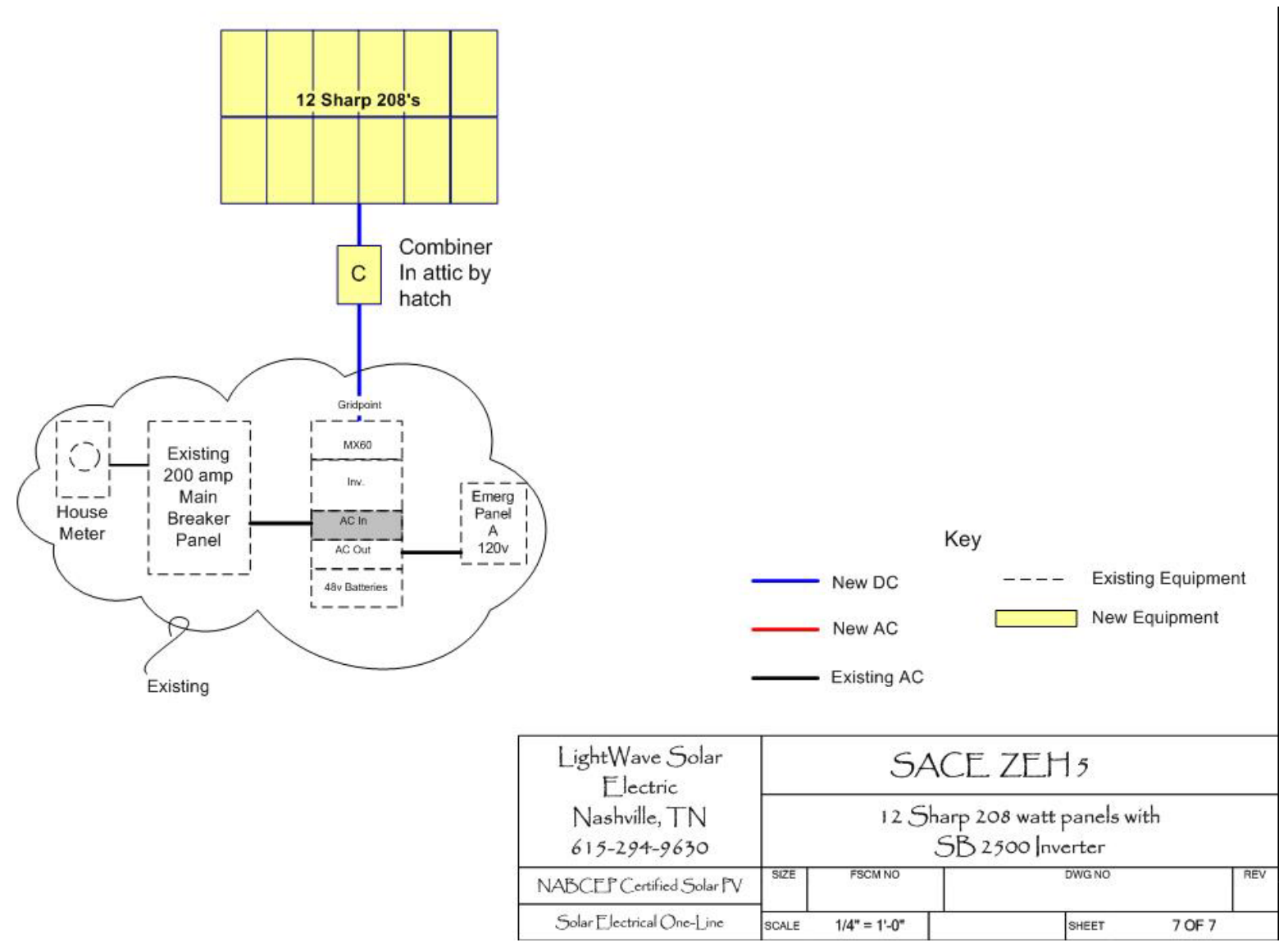

Fig. 47. Method used to tie the PV into the Gridpoint platform that houses the Outback inverter.

Total installed cost not including the Gridpoint platform was $\$ 17,150$. The modules, purchased from Big Frog Mountain (www.bigfrogmountain.com/) at a cost of $\$ 4.16 /$ watt, were attached directly to the raised metal seam roof using the S-5 mini clamps (40 at \$9.54 each plus shipping and handling for an additional $16 \%$ resulted in a final per-clamp cost of \$11.06). The installers did not like not being able to use the aluminum UNIRAC rails, which they felt allowed them to more easily wire the modules in series and hide the wires under the modules. The addition of the rails would have raised the modules another $4 \mathrm{in}$. from the top of the raised metal seam. 
Figure 48 shows the modules being installed on the roof of ZEH5. Costs of the modules and the inverter are expected to decrease. From February 2009 until October 2009, the retail cost for modules has dropped $10 \%$ as shown in Fig. 49.

The manufacturer suggests a clearance of at least 4 in. under the module to permit air circulation and cooler operating temperatures. Elevated temperature not only lowers operating voltage but also shortens service life. Figure 50 show evidence of some cooling behind the collectors.

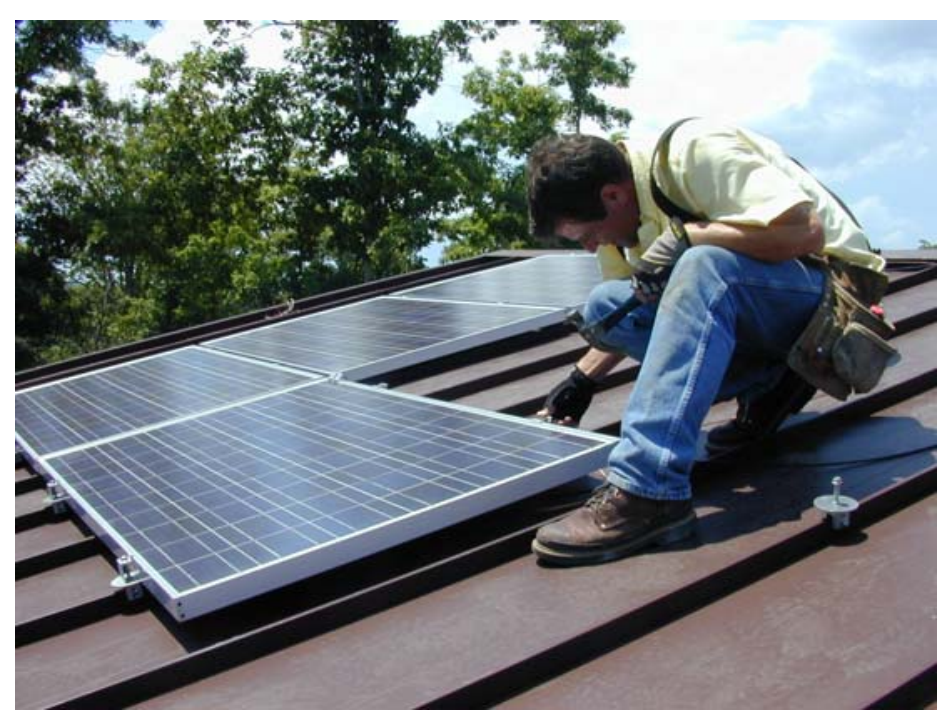

Fig. 48. Solar modules on the roof of ZEH5 are installed directly to the raised metal seam using the S5 mini clamps without the rails typically run parallel to the raised seams.

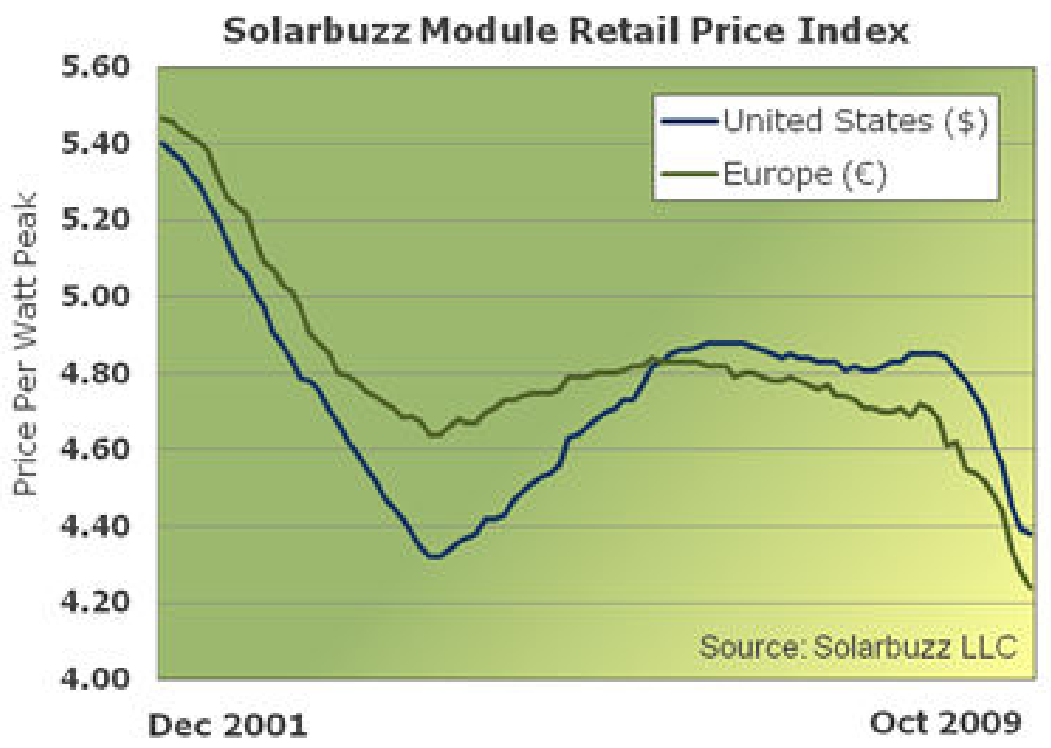

Fig. 49. Solar module cost in the United States and Europe, December 2001 to October 2009. Source: http://solarbuzz.com. 


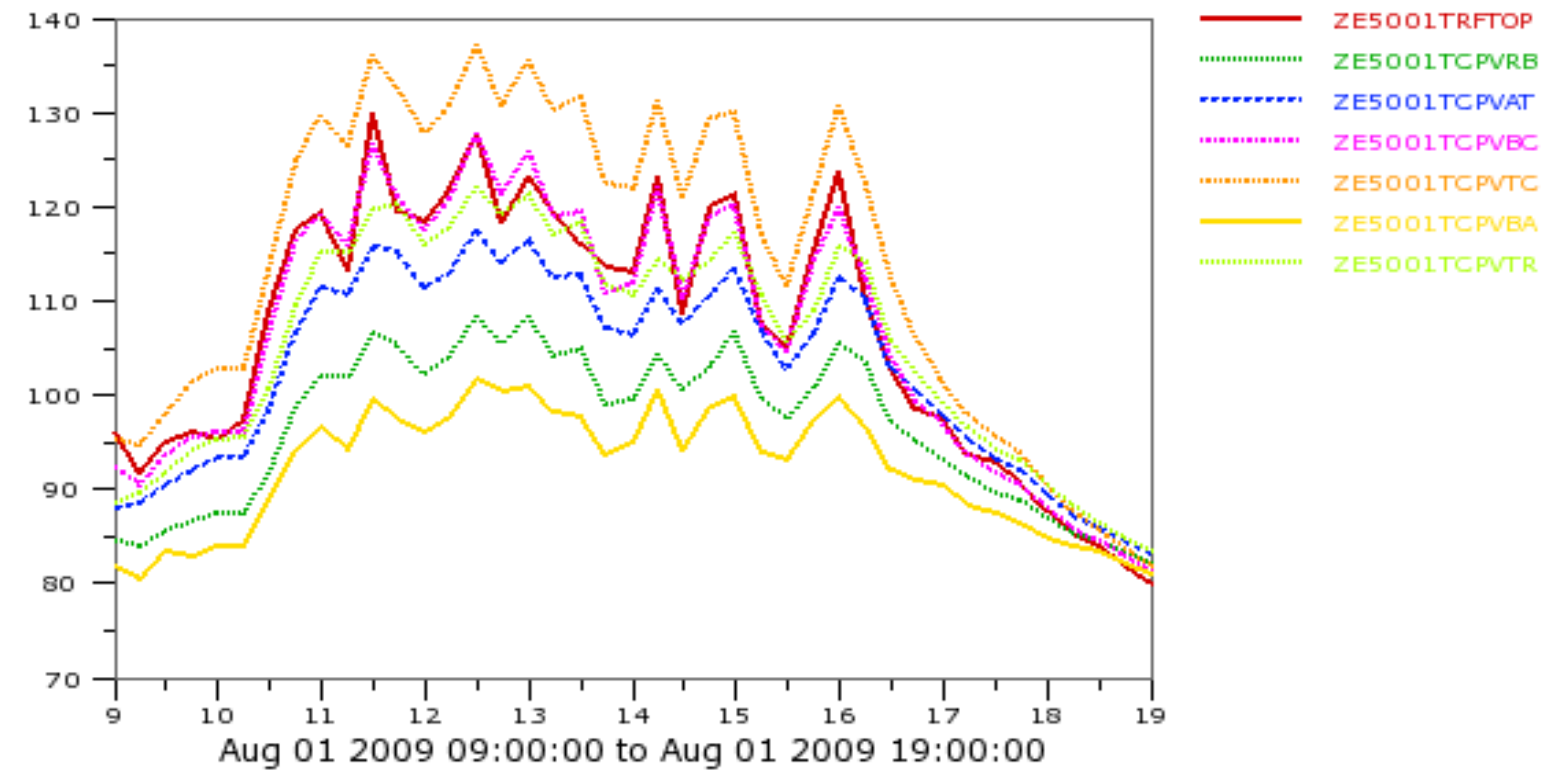

Fig. 50. Temperatures under the PV modules from 8:00 AM until 7:00 PM on August 1, 2009.

Thermocouples were attached to the bottom of the collectors, in the air stream between the collector and the roof and on the roof surface, both at the top of the array and at the bottom within one of the troughs formed by the 1.75 in. raised metal seam of the metal roof. The highest temperature was found at the back of the module at the top of the roof; $114^{\circ} \mathrm{F}$ (labeled PVTC in Fig. 50). The temperature at the bottom module in that column of three thermocouples averaged $107^{\circ} \mathrm{F}$ (labeled $\mathrm{BC}$ ). The air flow going into this trough averaged $92^{\circ} \mathrm{F}$ (labeled BA) and came out at $103^{\circ} \mathrm{F}$ (labeled AT). The temperature rise demonstrates heat is being carried away from the bottom of the modules. The roof temperature in the shade of the modules at the bottom averaged $96^{\circ} \mathrm{F}(\mathrm{RB})$ and at the top under the highest module on the roof was $105^{\circ} \mathrm{F}$ (TR). During the same period, the metal roof temperature in the full sun averaged $107^{\circ} \mathrm{F}$ (TRFTOP). August 1, 2009, had an average ambient air temperature during the day of $82^{\circ} \mathrm{F}$, wind speed of $4 \mathrm{mph}$ and clear skies except for some scattered clouds around 13:00 hrs. The bottom of the modules averages $110^{\circ} \mathrm{F}$ during the daylight hours $-28^{\circ} \mathrm{F}$ above the ambient air temperature.

The modules are 39.1 in. $\times 64.6$ in. and about 1.5 in. thick. Each module weights $46.3 \mathrm{lb}$. This amounts to an added dead load to the roof of $557 \mathrm{lb}$, about $164 \mathrm{lb}$ less than the $721 \mathrm{lb}$ of modules on ZEH4. The south-facing roof area of ZEH5 is $865 \mathrm{ft}^{2}$. The added roof dead load attributable to the solar modules amounts to less than $1 \mathrm{lb} / \mathrm{ft}^{2}$. The 12 modules will cover $210 \mathrm{ft}^{2}$ of roof area. In Knoxville's climate, to reach maximum energy efficiency (producing as much energy as it uses annually), ZEH5 would need about three times the roof area or $\left(630 \mathrm{ft}^{2}\right)$, which the south-facing single-ridge, double-eave roof could provide.

\subsubsection{Inverter}

ZEH5 used an Outback inverter onboard the Grid Point platform. The DC voltage coming from the PV is terminated to a Gridpoint Connect (Model C36-10-G2) appliance with an Outback inverter for converting DC voltage to AC and $10 \mathrm{kWh}$ lead-acid battery for energy storage (Boudreaux 2009). This appliance uses the PV power to charge the batteries, supply energy to the house, or feed excess energy to the grid. The stored energy in the batteries can be dispatched to the grid during peak load times or used to supply energy to the critical circuits during power outages. This feature was available in this house for another project, and its cost is not included in the neutral cash flow analysis. Instead, 
a Sunny Boy SWR 2500U inverter with onboard islanding protection and that meets UL 1741 was used for cost purposes. The unit is $17 \times 12 \times 8.5 \mathrm{in}$. and weighs $70 \mathrm{lb}$. The inverter location should be at eye level, as shown on ZEH4 in Fig. 51, on the north side under the extended roof overhang. The unit should not be in direct sun and exposure to rain should be minimized. There is no fan to dissipate heat; instead there is a heat sink mounted on the top that can reach $175^{\circ} \mathrm{F}$, so good natural air circulation around the inverter must be maintained.

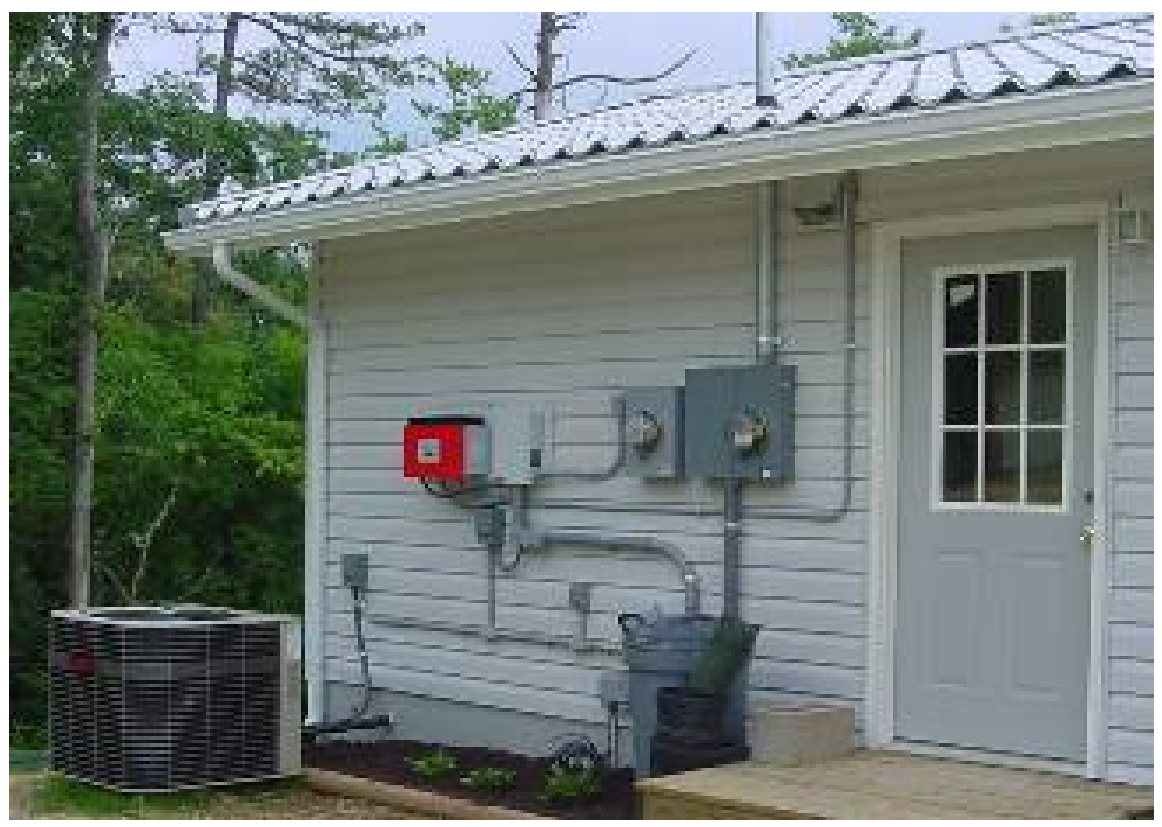

Fig. 51. Sunny Boy (red box at left) installed in TVA-approved Green Power Generation hookup. 


\section{WATER HEATING}

ZEH5 was designed with a antifreeze/water closed-loop solar water heater. (Figure 6 shows the collectors.) The ZEH5 solar water heater is a SolarRoofs, SkyLine System 5. This water heater was developed partially under a Technology Transfer Program managed by ORNL and funded by the DOE Office of Industrial Technology. One of the appealing features of this system is its ease of installation. The solar collectors are very light and can be placed into position quickly. A very good set of instructions and complete kit of parts was included that accommodated the overall ZEH design concept of minimizing first costs by making the assembly of the entire house very easy and "kitfriendly." (For ZEH5, the August 2005 version of these instructions was used. The link for current installation instructions can be found in Appendix B, Resources. We used the August 2005 version of these instructions.)

The 2005 material cost including the 80 gal tank was $\$ 2400$. The installation took 1 day2 person-days by two Habitat volunteers with modest plumbing experience. It is estimated that the total installed cost value would have been $\$ 3200$ with professional installers.

This solar water heater system meets the Solar Rating and Certification Corporation standard. Two $20 \mathrm{ft}^{2}$ solar panels were mounted on the raised metal seam roof of ZEH 5 (Fig. 6). Figure 6 also shows the two penetrations for the pipes leading to and from the water tank. The S5 mini clips, shown in Fig. 32, were used for both the solar collectors and the small $20 \mathrm{~W}$ PV module for powering the 12 V DC circulation pump. The controls are entirely solar-dependent. When the PV collector voltage reaches a minimum threshold, the pump is powered and circulation is initiated. A flow meter installed in the loop measured a maximum circulation of $0.41 \mathrm{gpm}$. The 80 gal heat exchanger storage tank is a Rheem/Rudd/Richmond Model Number 81V080HE180. 



\section{APPLIANCES}

For maximum energy efficiency, Energy Star appliances, including ceiling fans, should be purchased whenever possible. Refrigerators and clothes washer manufacturers in particular have made significant energy savings improvements in the last decade. Including more efficient appliances in the mortgage of the new home means that the slightly higher first costs are spread over the life of the mortgage and are offset by lower energy costs. Built-in Energy Star entertainment centers and home office equipment should also be considered. LCD screens should be selected over plasma screens. Energy Star ratings are updated periodically, and often, available options go beyond Energy Star standards.

ZEH5 has a Whirlpool $18 \mathrm{ft}^{3}$ Energy Star refrigerator that was donated by the Whirlpool Corporation. In August 2007, a small Kill-A-Watt meter measured an average daily refrigerator energy consumption of $0.97 \mathrm{kWh} / \mathrm{d}$. The kitchen temperature during that period was $73^{\circ} \mathrm{F}$, though the house functioned as an office rather than a home kitchen. 



\section{RECOMMENDATION}

ZEH5 served as a very good resource for conducting affordable high performance home research. Several of its features were dictated by the Habitat for Humanity constraints. There has been considerable interest in this research. It has prompted more than 1000 e-mails, many inquiring about how to purchase plans for a similar high performance home with some simple adjustments for adaptability in different climates. Interested potential owners were invited to several group design charrettes lead by Beth Eason from Eason Architects in Knoxville, Tennessee. These sessions provided guidance for adjusting the designs for very similar energy performance. The designs developed without the Habitat constraints that were necessary for the original project were more commercially attractive one- and two-story models. A flyer was generated to summarize the final product of these efforts. The one-story version was called ZEH6; the two-story, ZEH7. This report focuses on the ZEH6 design, which has all the same features of ZEH5 except that the geothermal heat pump is replaced with a SEER 16 air source unit (as used in ZEH4). The plans for the ZEH6 house are displayed in Figs. 52-60.

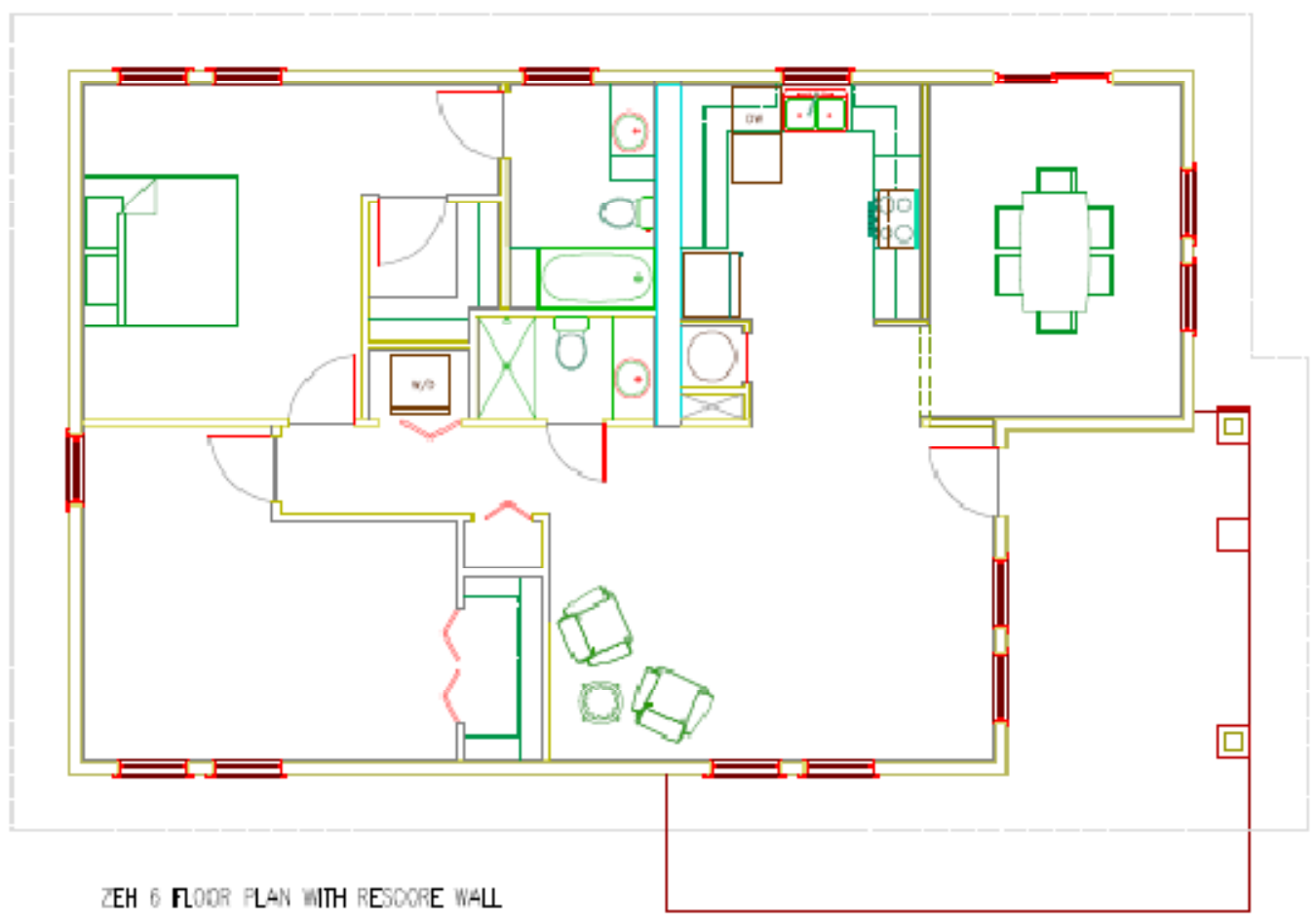

Fig. 52. ZEH6 floor plans. 

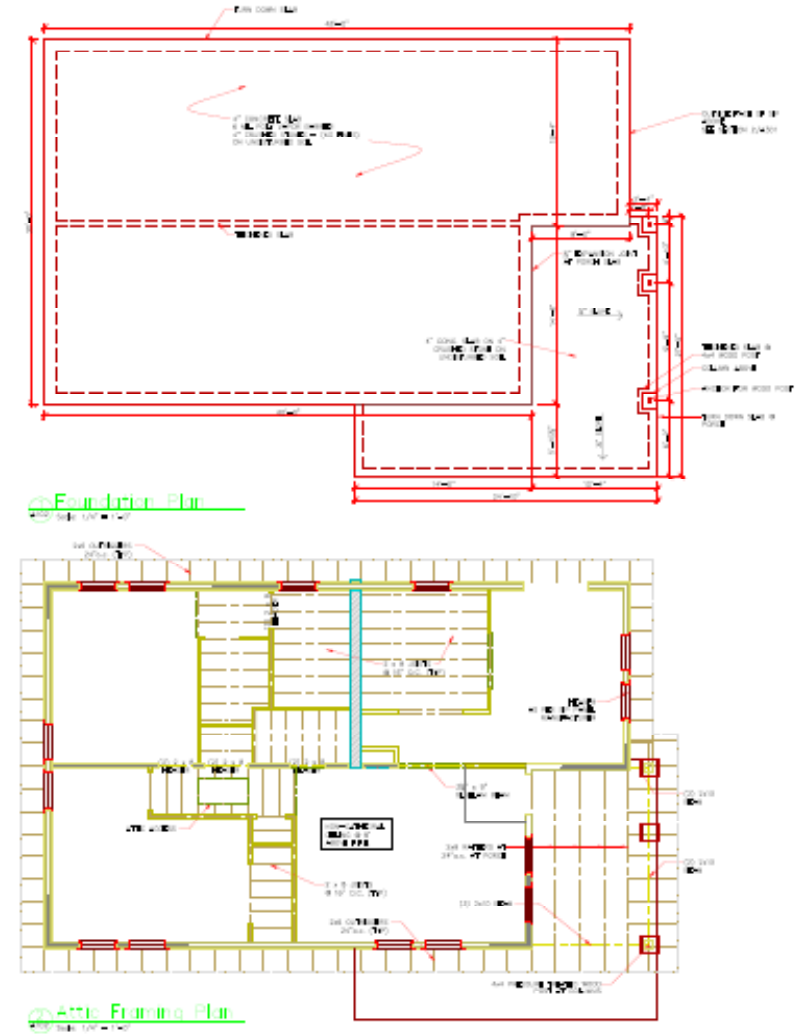

-...111

Fig. 53. Foundation and dropped ceiling plans.
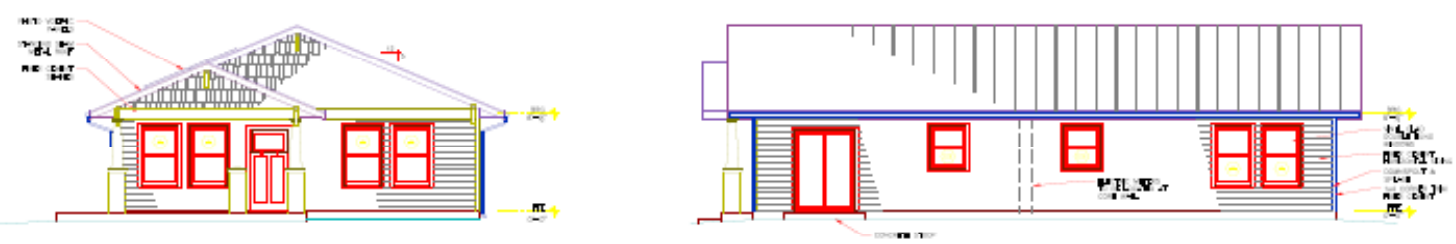

$\frac{E_{1}-E_{1}-111}{2-1-210}$

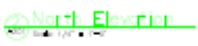
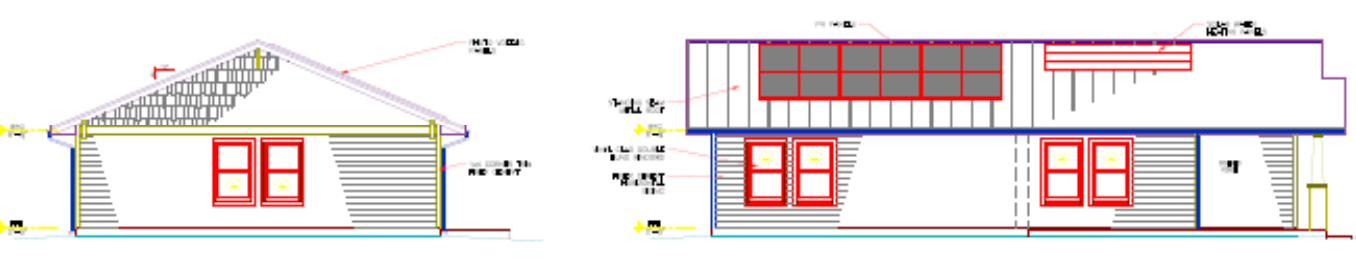

-. El El $1+11$

$$
\text { -. }
$$

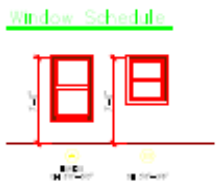

Fig. 54. ZEH6 elevations. 

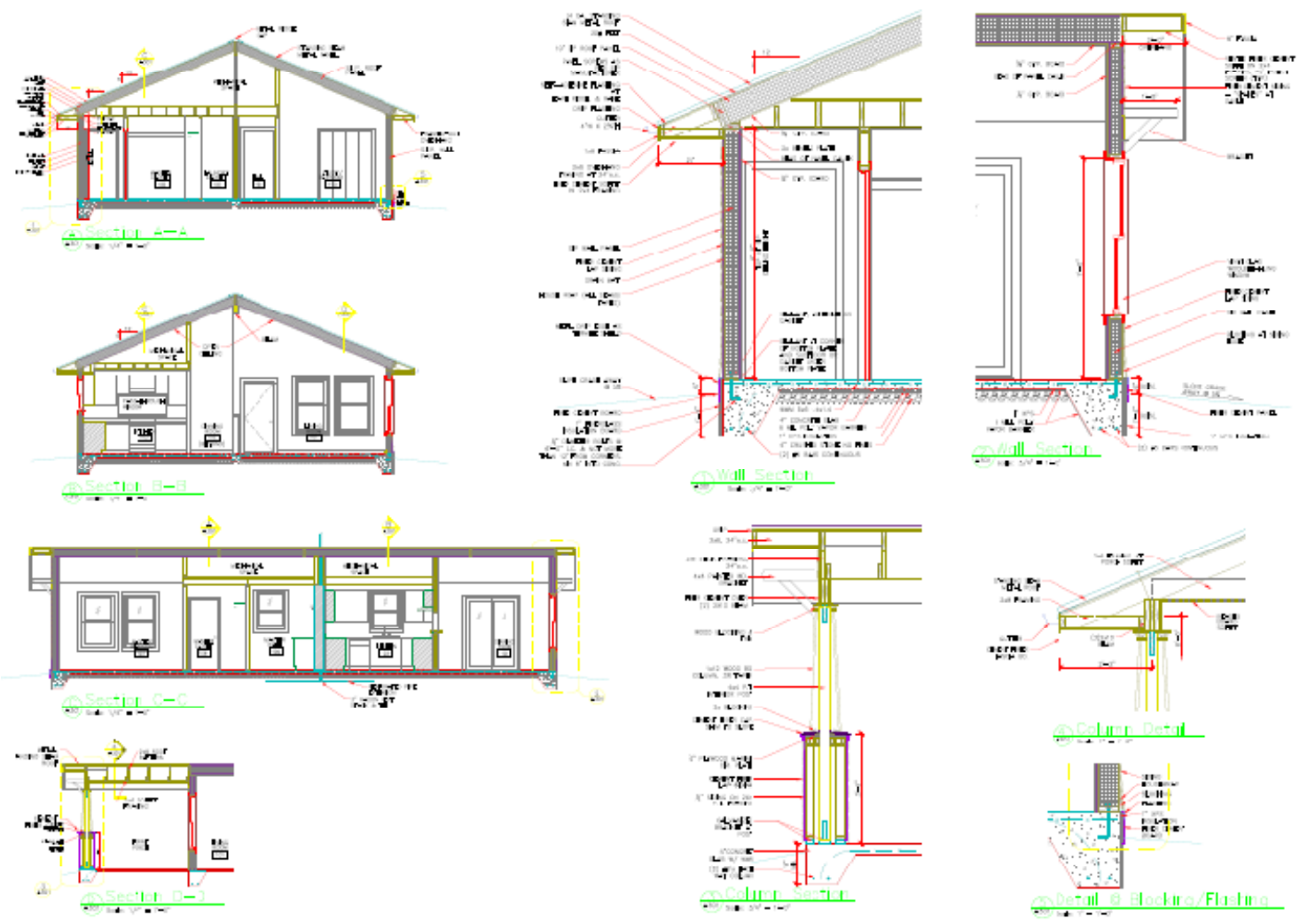

Fig. 55. ZEH6 cross sections.
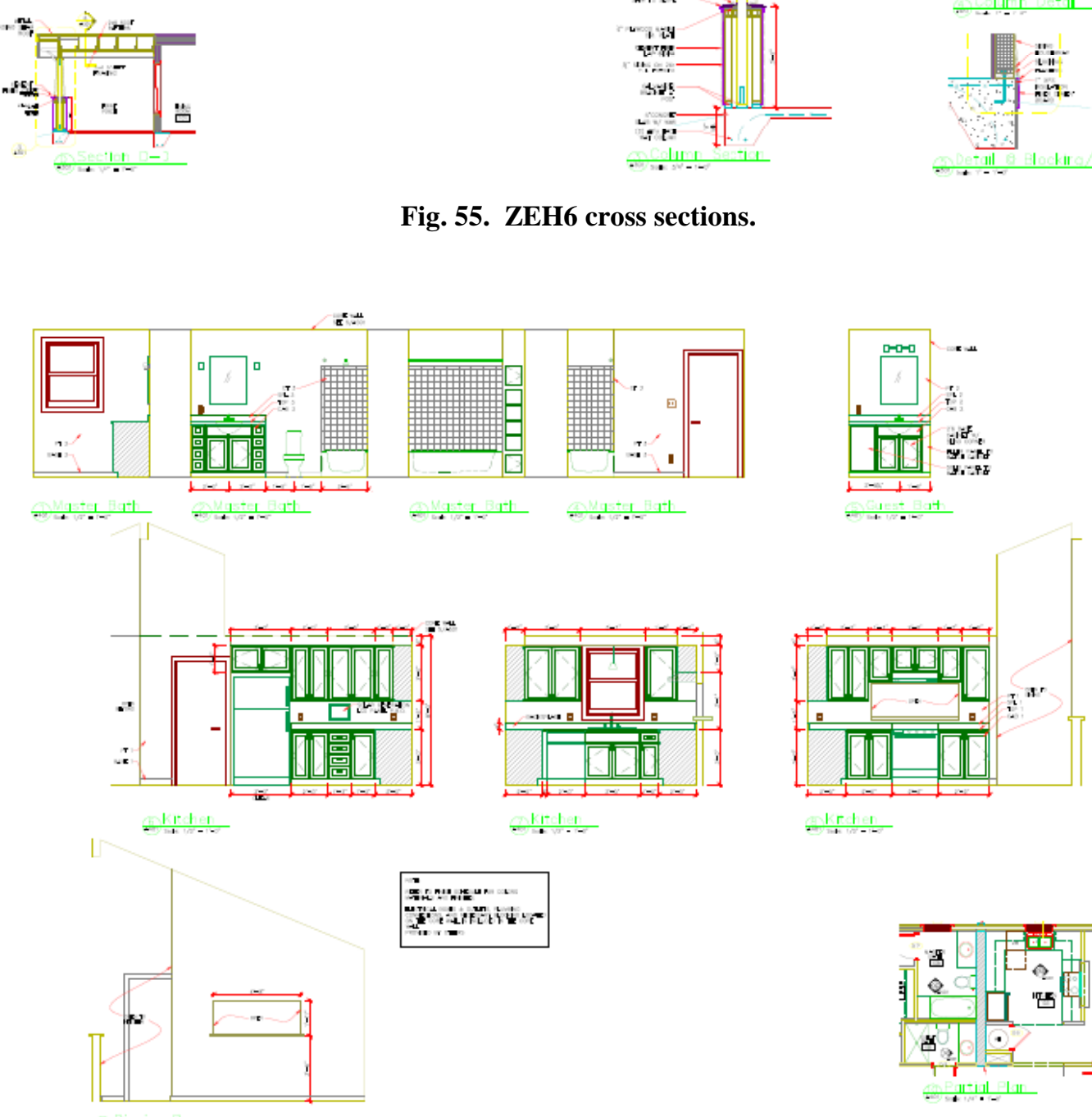

Fig. 56. Kitchen and bath elevations.

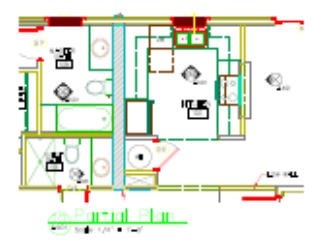




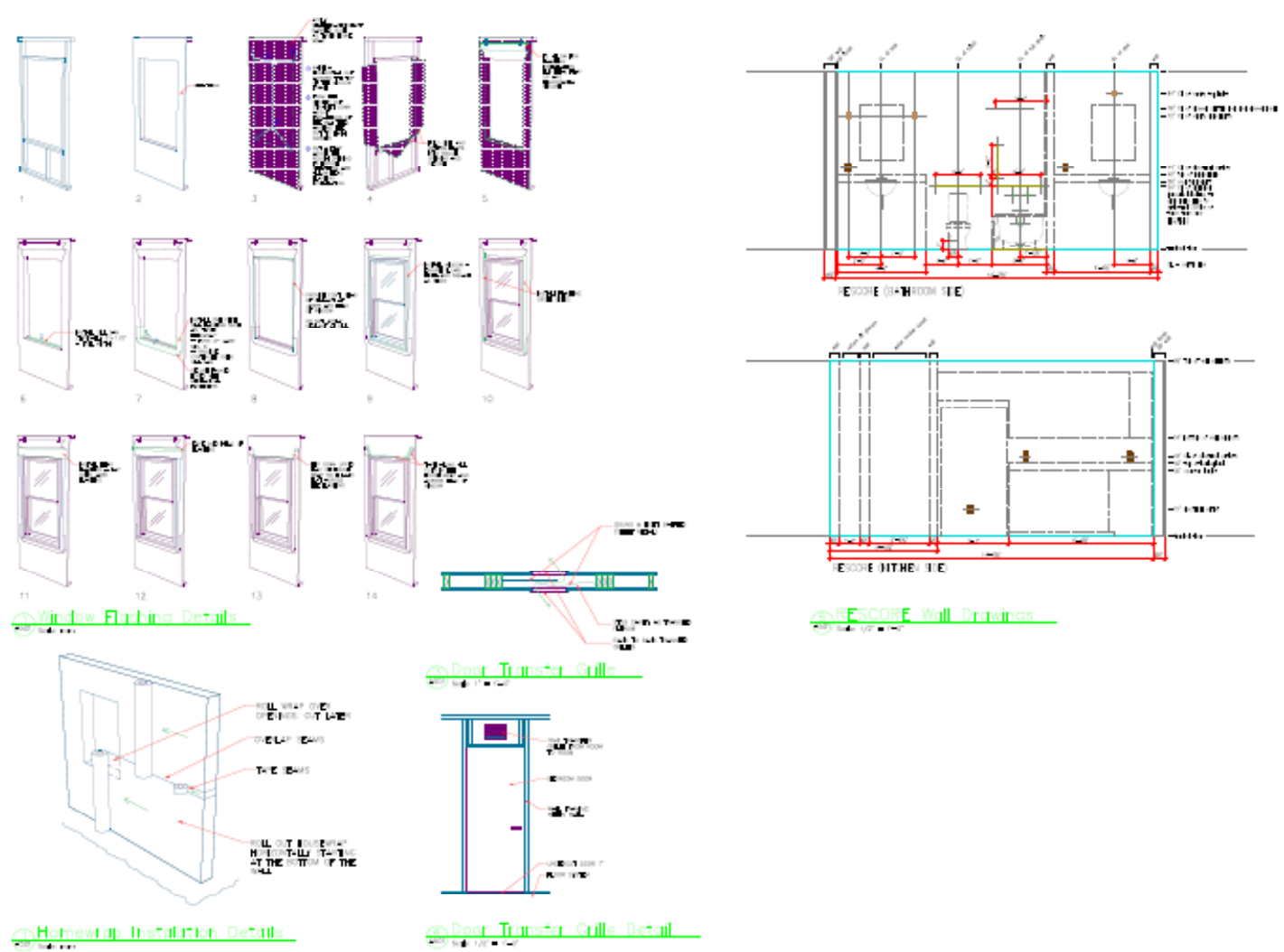

Fig. 57. Important installation details.

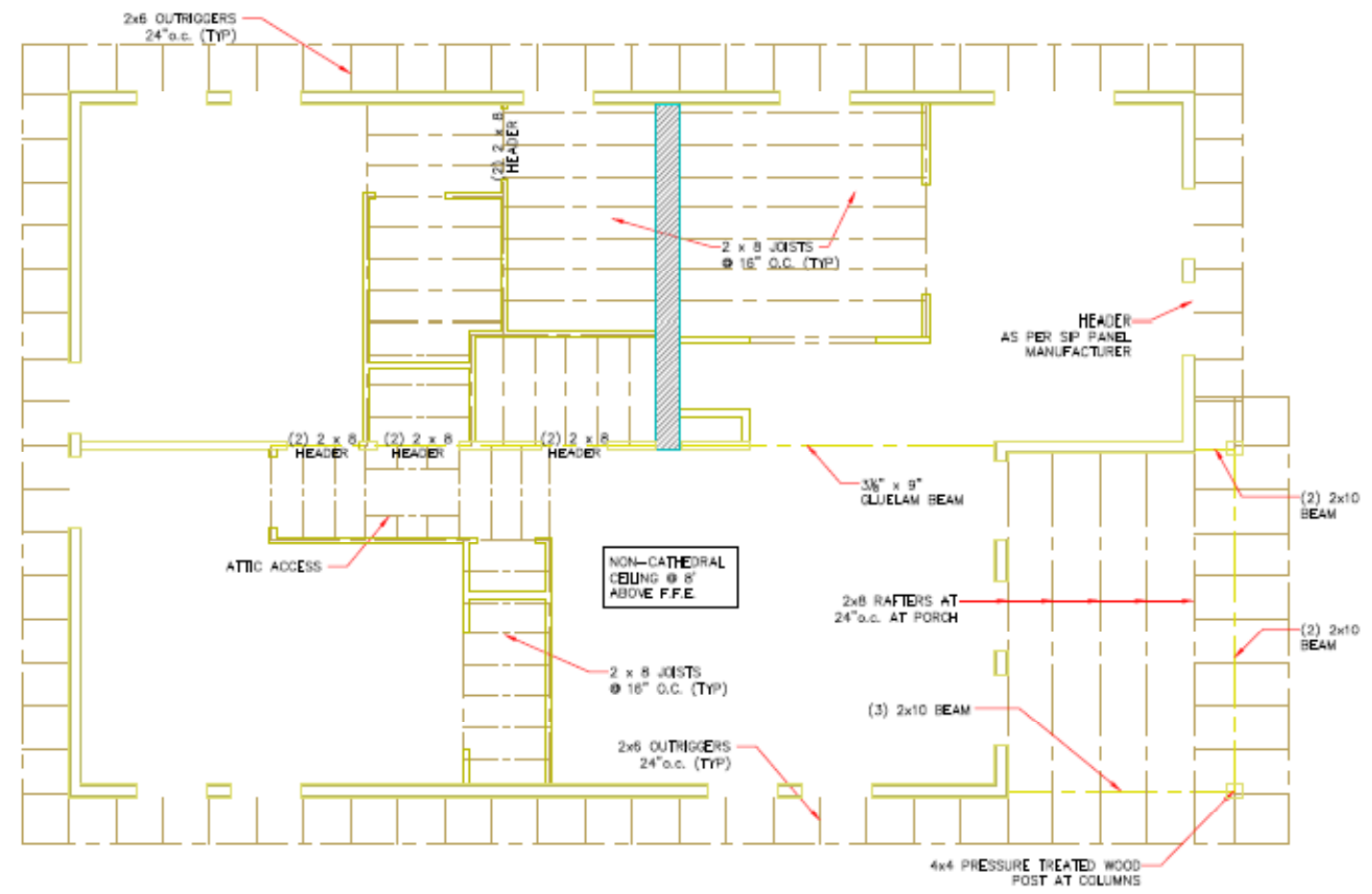

Fig. 58. Dropped ceiling plan. 

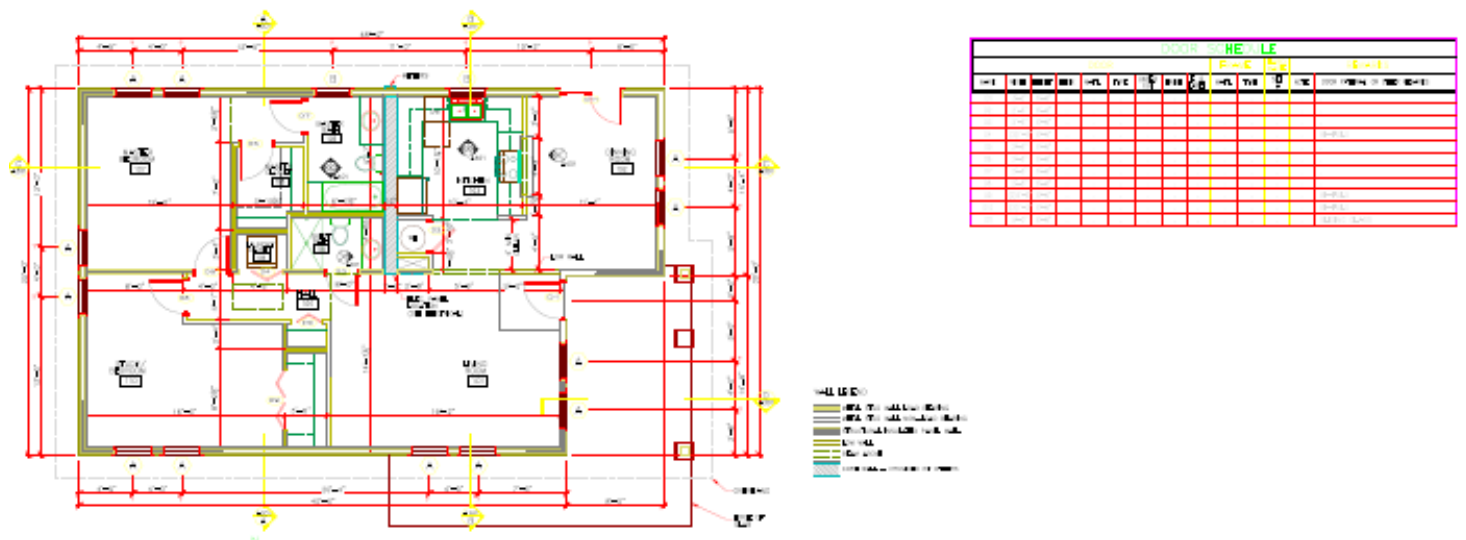

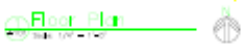
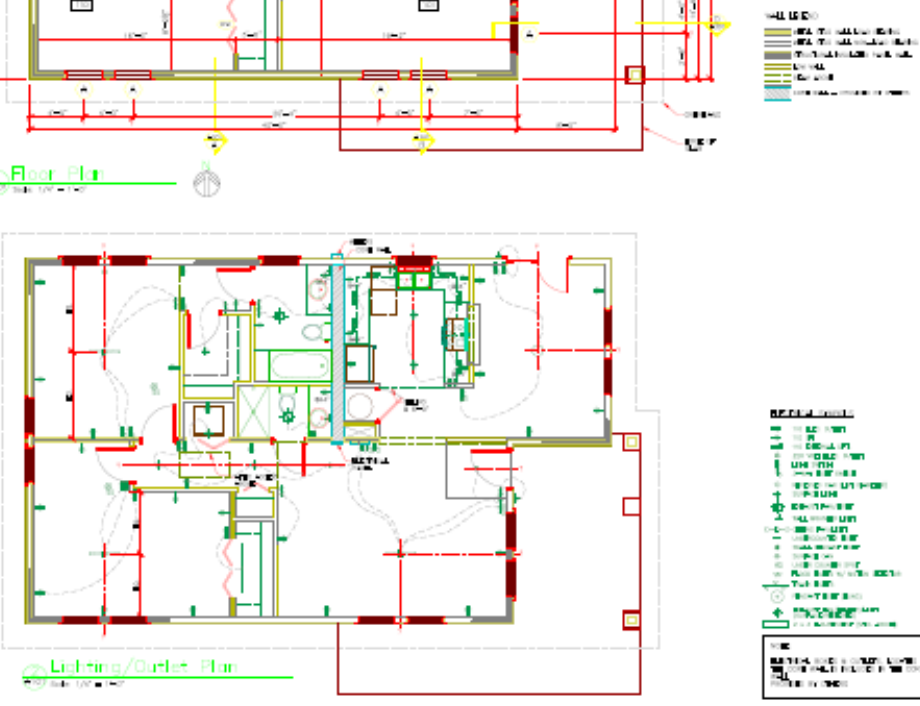

Fig. 59. HVAC duct design plan.
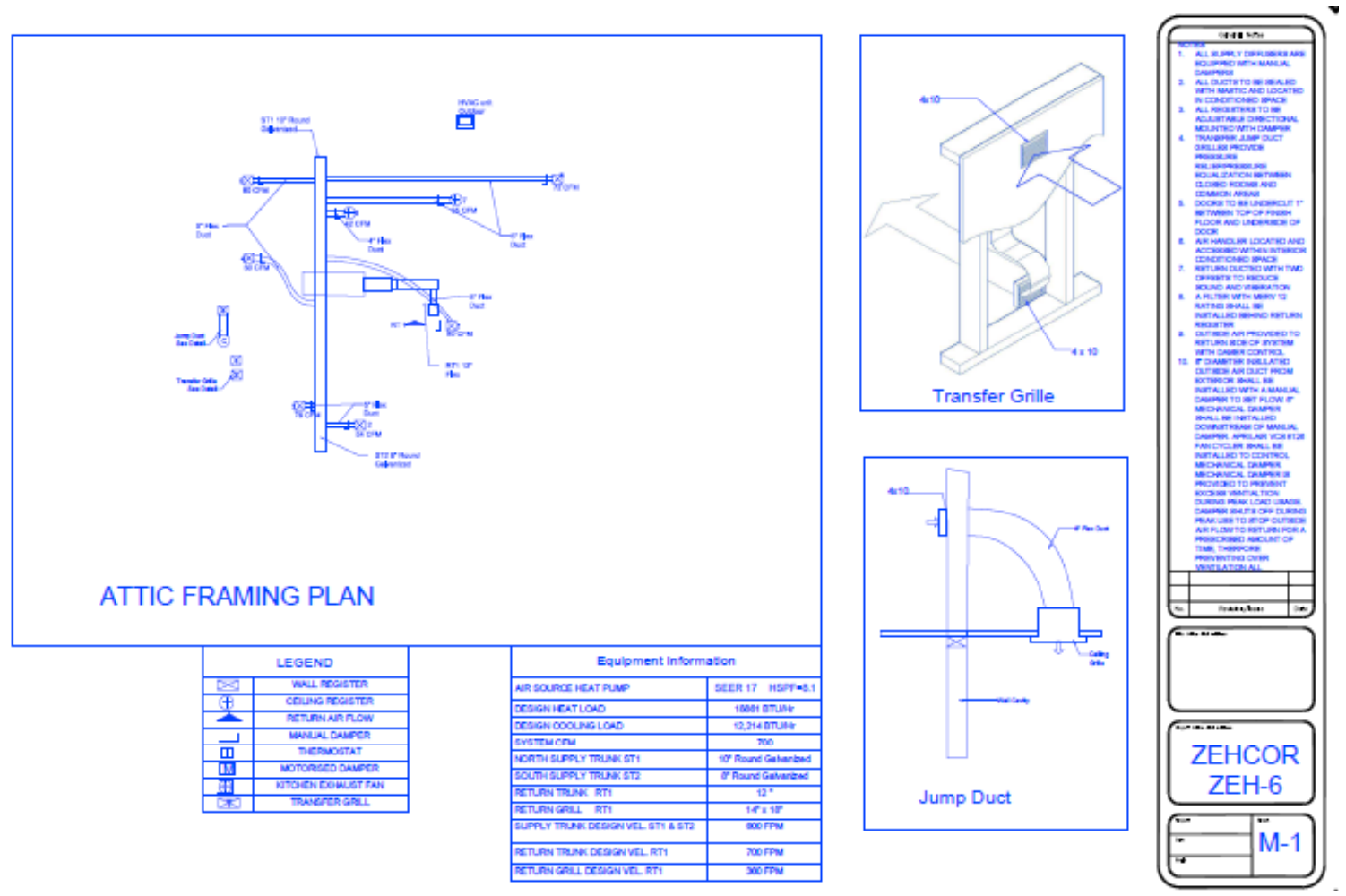

Fig. 60. HVAC design details. 
ZEH6 was modeled using EnergyGauge USA in five cities across the TVA service territory. The resulting HERS ratings are shown in Fig. 61. The same house placed in all climates results in the lowest HERS for Memphis with 36 and the highest in Bristol with 46. Memphis has the most cooling degree days but the most sun. Bristol has the highest amount of heating degree days (as seen in Table 13).

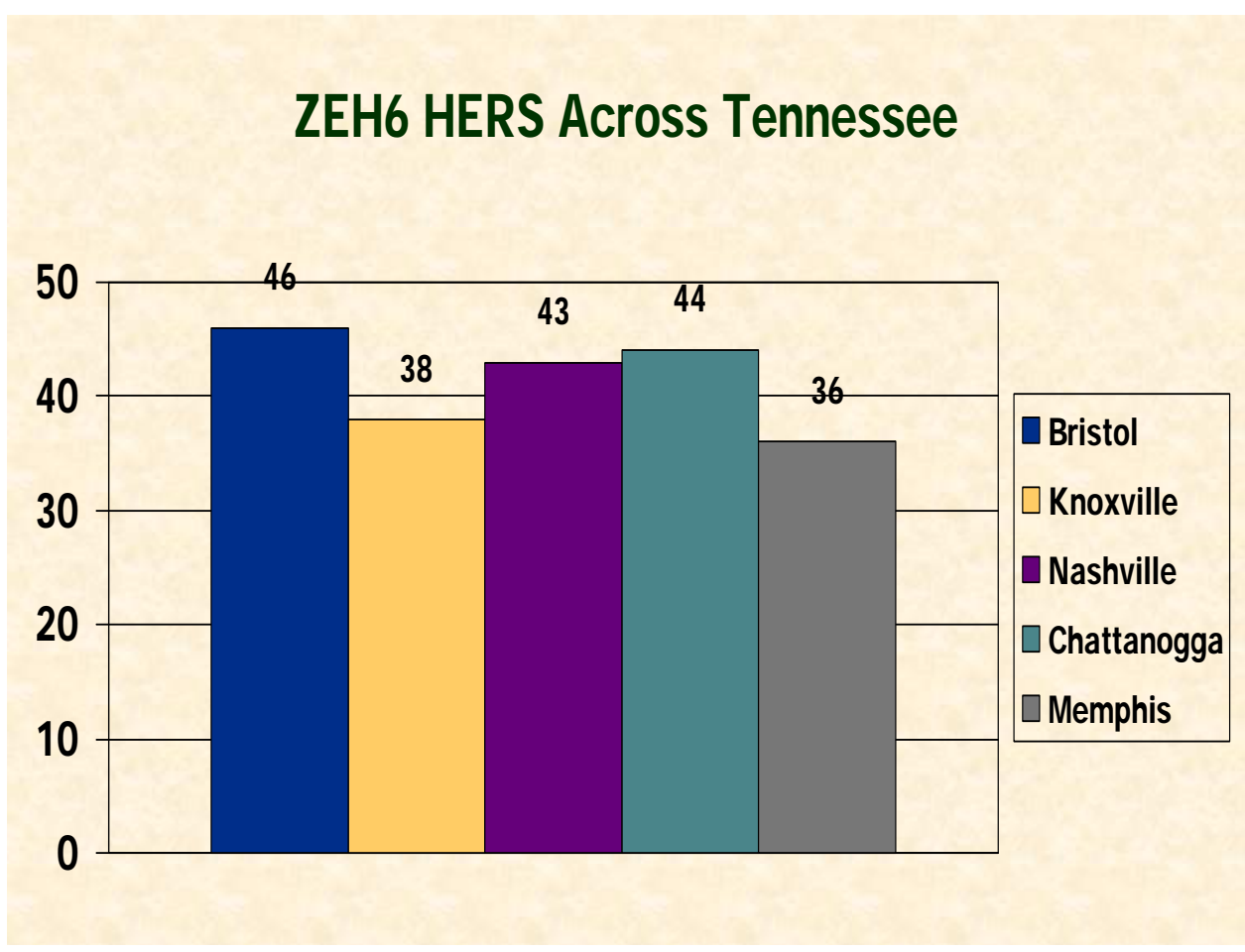

Fig. 61. ZEH6 HERS ratings for five cities across the TVA service territory.

Table 13. Heating degree days (HDD) and cooling degree days (CDD) for cities across the TVA service territory

\begin{tabular}{lccc}
\hline \multicolumn{1}{c}{ City } & $\mathbf{H D D} @ \mathbf{6 5}^{\circ} \mathbf{F}$ & $\mathbf{C D D} @ \mathbf{6 5}^{\circ} \mathbf{F}$ & $\begin{array}{c}\text { Sum } \\
\text { HDD + CDD }\end{array}$ \\
\hline Knoxville & 3662 & 1365 & 5027 \\
Memphis & 3108 & 1998 & 5106 \\
Chattanooga & 3534 & 1585 & 5119 \\
Bristol & 4345 & 928 & 5273 \\
Nashville & 4031 & 1672 & 5703 \\
\hline
\end{tabular}

A perspective drawing of ZEH6 is shown in Fig. 62.

Table 13 provides the heating degree and cooling degree days (base $65^{\circ} \mathrm{F}$ ) for the five cities in which ZEH6 energy performance is simulated. These data indicates that generally, the higher the values, the more heating and cooling energy is expected to be needed under the same internal usage. A summation of the HDD and CDD gives a very simplistic indicator of the severity of climate. Knoxville has the lowest sum and Nashville has the highest. 


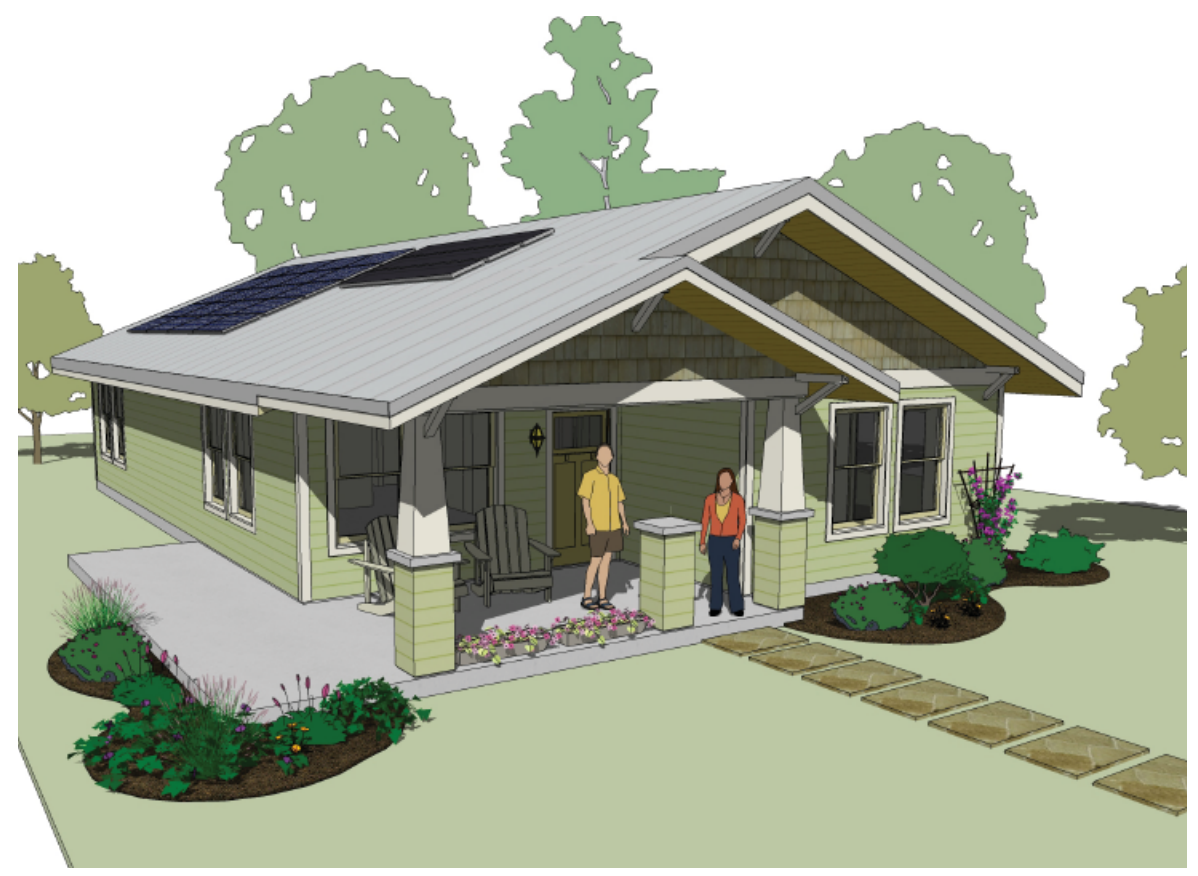

Fig. 62. Perspective drawing of ZEH6 by Eason Architects.

It is suggested that TVA facilitate the construction of ZEH6 near each of the 5 locations and conduct at least some degree of sub-metering of electrical usage to isolate the HVAC, water heating, and solar PV generation from the whole-house loads. The test houses in Lenoir City that TVA agreed to help fund in 2002 have been an enormous success. ORNL has provided hundreds of tours and spoke to thousands of interested people at conferences and workshops across North America. Being able to "kick the tires" of a model house is invaluable with respect to capturing the public's attention for energy efficiency potential. 



\section{SUMMARY}

Compared with a new code-compliant house in the TVA service territory, the homes discussed in this report will use 50\% less energy. This report compares the energy performance of a house built in the Knoxville area to that of the Building America benchmark house (essentially a conventional new home in 2009). Results show that the studied house can reduce energy usage by $54 \%$ without solar PV panels, and by $67 \%$ with PV panels. Moreover, HERs values range from 38 to 46 (0 is zero energy, 100 is typical new construction), less than half that of a conventional new home. These homes have very small energy loads and with a $2.5 \mathrm{~kW}$ peak solar PV system can produce about a third of the energy needed by an average family.

A neutral cash flow analysis was conducted that shows that these homes had a positive cash flow during the first year of occupancy with the current available incentives, the residential electric rate of $\$ 0.10 / \mathrm{kWh}$, and the solar buy back of $\$ 0.22 / \mathrm{kWh}$. Furthermore, the positive cash flow could be put into the purchase of renewable energy from TVA's Green Power Switch Program to cover the net energy purchased from the grid for an annual net cost of only \$18/yr. This house could then be considered to operate completely on renewable energy.

This report is intended to help builders and homeowners make the decision to build a maximum energy efficiency home in the TVA service territory. Detailed drawings, specifications, and lessons

learned are presented in this report. Results are based on the comprehensive analysis of data from 94 sensors that monitored the thermal performance of the studied house for 1 year. 



\section{REFERENCES}

ACCA. 2006. "Residential Duct Systems Manual D" and "Residential Load Calculations Manual J," Air Conditioning Contractors of America, 2800 Shirlington Road, Suite 300, Arlington, VA 22206, www.acca.org

ASHRAE. 2004. "Ventilation and Acceptable Indoor Air Quality in Low-Rise Residential Buildings." American Society of Heating, Refrigerating, and Air-Conditioning Engineers. ANSI/ASHRAE 62.2-2004. Atlanta, Ga.: American Society of Heating, Refrigerating, and AirConditioning Engineers.

Boudreaux, P, Gehl, T., and Christian, J., "The role of solar energy toward the goal of zero-energy homes in USA mixed-humid climates," in Solar 2009, Buffalo, NY, May 2009

Christian, Jeffrey E. 2005. "Ultra-Low-Energy Residences.” ASHRAE Journal. January.

Christian, Jeffrey E., and Jan Kosny. 1995. "Towards a National Opaque Wall Rating Label." In Proceedings for ASHRAE/DOE Thermal Performance of the Exterior Envelope of Buildings Conference VI, Clearwater Beach, Fla., December 4-8.

Christian, Jeffrey E. 1996. "Thermal Performance and Wall Ratings.” ASHRAE Journal, 38(3). March.

Christian, Jeffrey E., Paige Pate, Phil Childs, and Jerry Atchley. 2006a. "Small House With Construction Cost of \$100K, Total Energy Cost of \$0.88 a Day." Presented at 2006 ASHRAE Winter Meeting; Published in ASHRAE Transactions, 112(1).

Christian, Jeffrey E., Lauren Richards, Phil Childs, Jerry Atchley, and Hyeun Moon. 2006b. "Energy Efficiency, SIPS, Geothermal, and Solar PV Team Up to Near-Zero-Energy House.” Presented at 2006 ASHRAE Winter Meeting; Published in ASHRAE Transactions, 2006-2.

Christian, Jeffrey E. 2007. "Energy Savings from Small Near-Zero-Energy Houses Integration." FEMP Technology Installation Review. May. www1.eere.energy.gov/femp/pdfs/tir_zeroenergyhouses.pdf

Christian, Jeffrey E, 2008 “Zero Energy Peak: Annual Zero Energy Ready,” ACEEE 2008 Summer Study, August 2008.

DOE. 2004. “Typical Appliance Usage.” 2004 Buildings Energy Databook, Table 7.2. Washington, D.C.: U.S. Department of Energy.

EIA. 2010. (US Energy Information Administration). EIA website "Average Retail Price of Electricity to Ultimate Customers by End-Use Sector, by State," Tables 5 and 6. www.eia.doe.gov/cneaf/electricity/epm/table5_6_a.html.

FSEC, Florida Solar Energy Center, EnergyGauge, 2006.

Headley, James. 2005. "Rigging," Crane Institute of America Publishing \& Products, Inc., 3880 St. Johns Parkway, Sanford, Fl 32771. www.craneinstitute.com.

NREL. 2008. Building America Research Benchmark Definition, Updated December 19, 2008, by Robert Hendron. NREL/TP-550-44816. http://apps1.eere.energy.gov/buildings/publications/pdfs/building_america/44816.pdf.

Hendron, R., et al. 2004. "Building America Performance Analysis Procedures, Rev. 1." NREL/TP550-35567. Golden, Colo.: National Renewable Energy Laboratory.

Henry, Stuart. 2007. Barge, Waggoner, Sumner \& Cannon, personal communication with Jeff Christian on August 29, 2007, www.bargewaggoner.com.

Morley, Michael, 2000, "Building with Structural Insulated Panels," The Taunton Press Inc., 63 South Main Street, PO Box 5506, Newtown, CT 06470-5506, tp@taunton.com.

Parker, D. S., J. E. R. McIlvaine, S. F. Barkaszi, and D. J. Beal. 1993. "Laboratory Testing of Reflectance Properties of Roofing Materials," Report No. FSEC-CR-670-93. Cape Canaveral, Fla.: Florida Solar Energy Center.

RESNET. 2002. Residential Energy Services Network. 2002. http://www.resnet.us/standards. 
Rutkowski, Hank. May 2004. "Manual J Residential Load Calculation,” Air Conditioning Contractors of America, 2800 Shirlington Road, Suites 300, Arlington, VA 22206. www.acca.org.

Vineyard, E. A., et al. 2003. "Measured Performance of Conventional and High-Velocity Distribution Systems in Attic and Space Locations." ASHRAE Transactions, 109(2). June. 


\section{APPENDIX A: GEOTHERMAL HEAT PUMP PERFORMANCE ISSUES AND ASSOCIATED DATA}

As a result of some technical issues with the geothermal heat pump (GHP) system, system, the cooling energy consumed by the GHP was found to be much higher than experienced prior to occupancy on October 28, 2008. A discussion of the GHP and its performance can be found in Appendix A.

The occupants had programmed the thermostat to cool starting May 1 to swing from $78^{\circ} \mathrm{F}$ during the day from 8:00-17:00 to $75^{\circ} \mathrm{F}$ for the remainder of the day. Starting on July 1, 2009 this was changed to $76^{\circ} \mathrm{F}$ during the day and $75^{\circ} \mathrm{F}$ at night. The energy efficiency rating (EER) used in the EnergyGauge software program (with DOE 2.2 engine) that calibrated with the measured cooling consumption prior to occupancy was 15.5. This accounted for the loop pumping power. An EER of 10 was used to generate an estimate for cooling energy (see Table A.1). This still results in an under prediction of the cooling energy measured to serve this house with six to nine occupants from November 1, 2008-October 31, 2009. The lowest value allowed in EnergyGauge's computer simulation of energy performance is 10 . To match the high measured cooling energy demand would have required an EER of 6.5. Data had been collected for this unit since 2006; this was its fourth summer of use. Other than a lost charge incident that was corrected in June 2007, the unit had always been able to maintain set point and had never tripped due to a hot loop.

Table A.1. ZEH5 two-story measured energy use compared with calibrated model, November 2008-October 2009

\begin{tabular}{lcccccc}
\hline \multicolumn{1}{c}{ Month } & $\begin{array}{c}\text { Space heat } \\
(\mathbf{k W h})\end{array}$ & $\begin{array}{c}\text { Space cool } \\
(\mathbf{k W h})\end{array}$ & $\begin{array}{c}\text { Solar WH } \\
\text { backup } \\
(\mathbf{k W h})\end{array}$ & $\begin{array}{c}\text { Other } \\
(\mathbf{k W h})\end{array}$ & $\begin{array}{c}\text { Total } \\
(\mathbf{k W h})\end{array}$ & $\begin{array}{c}\text { Solar } \\
\text { generation } \\
(\mathbf{k W h})\end{array}$ \\
\hline Nov.-2008 & 176 & & 107 & 458 & 741 & 169 \\
Dec. & 326 & & 151 & 610 & 1087 & 218 \\
Jan. & 491 & & 158 & 599 & 1248 & 237 \\
Feb. & 334 & & 61 & 704 & 1099 & 299 \\
Mar. & 222 & & 105 & 816 & 943 & 308 \\
April & 144 & & 51 & 525 & 720 & 335 \\
May & & 321 & 36 & 554 & 911 & 316 \\
June & & 642 & 5 & 452 & 1099 & 323 \\
July & & 621 & 2 & 472 & 1095 & 289 \\
August & & 856 & 2 & 501 & 1359 & 298 \\
Sept. & & 652 & 26 & 714 & 1392 & 206 \\
Oct. & & 338 & 87 & 585 & 1010 & 154 \\
Measured & 1693 & 3430 & 791 & 6990 & 12,704 & 3152 \\
Calibration & 1688 & 2099 & 786 & 6989 & 11,562 & 3074 \\
$\quad$ model & & & & & & \\
Measured & & & $0.6 \%$ & $0 \%$ & $9.9 \%$ & $2.5 \%$ \\
$\quad$ vs. model & $0.3 \%$ & $63 \%$ & & & & \\
\hline
\end{tabular}

Figure A.1 shows the measured monthly maximum, average, and minimum entering water loop temperature for the last 4 years. This plot shows that the loop was actually a bit cooler in the summer of 2009 than in the previous 3 years.

The daily average run time supply and return temperatures for the heat pump are plotted in Fig. A.2 for the cooling season from May 1 until Sept 30, 2009. The Y axis in Fig. A.2 is temperature $\mathrm{F}$ and the $\mathrm{X}$ axis is the Julian day of the year. The run time supply temperature starting around the 
middle of June is averaging around $67^{\circ} \mathrm{F}$. This is too high and indicates a problem with the unit's ability to cool.

\section{Entering water loop temp \\ from Feb 1, 2006 - September 30, 2009}

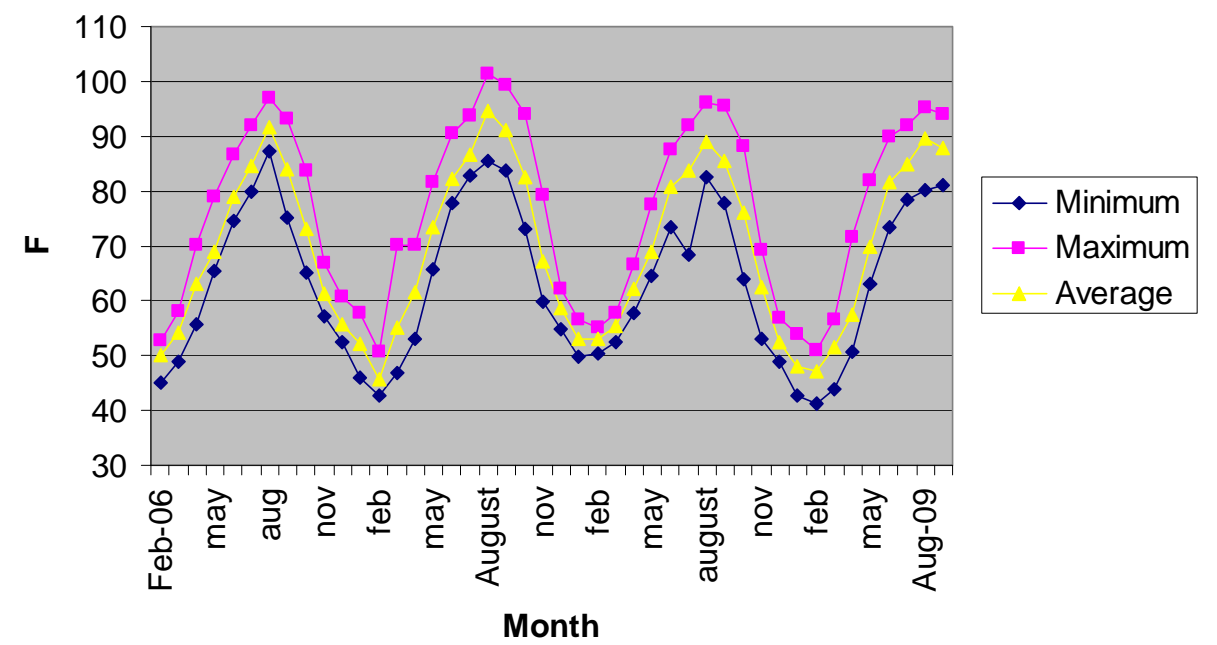

Fig. A.1. Entering water loop temperature from February 2006September 2009.

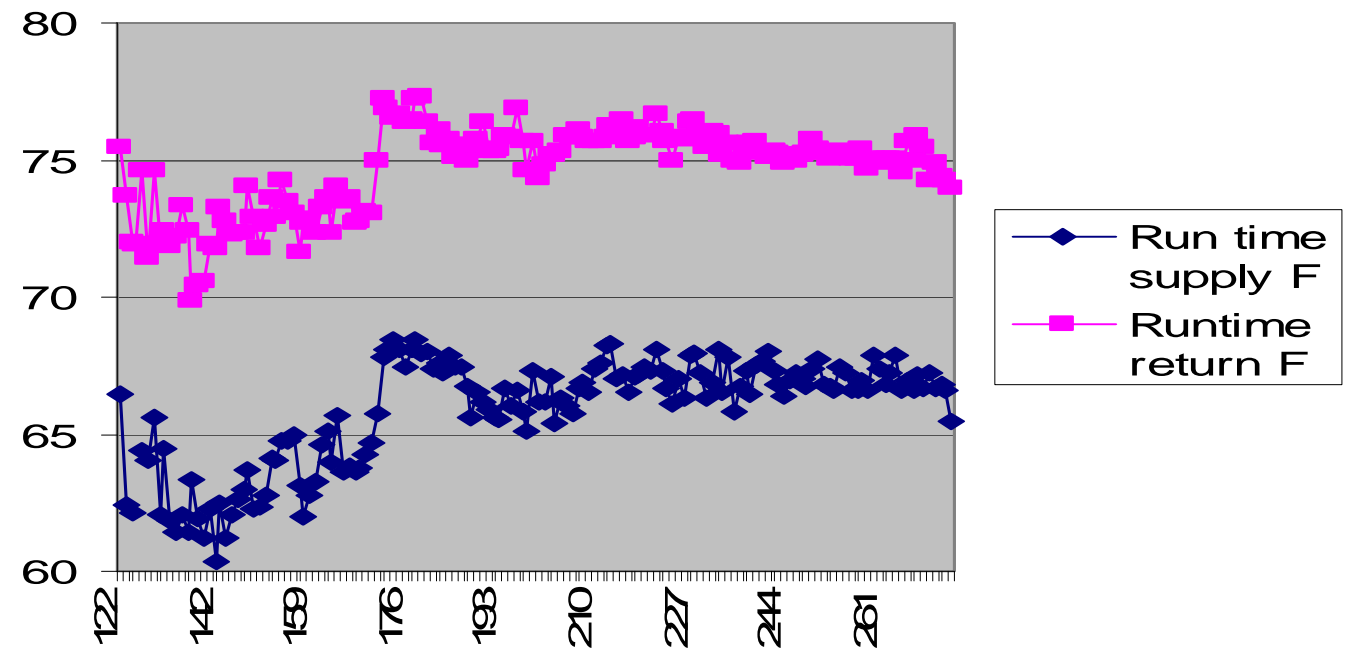

Fig. A.2. Geothermal heat pump runtime supply and return average daily air temperature.

Figure A.3 shows that on August 10, 2009, the heat pump maintained temperature and did a fair job of controlling relative humidity $(\mathrm{RH})$. The top line represents basement temperature; the second from the top is the upstairs temperature taken just above the thermostat in the center of the house. The average $\mathrm{RH}$ is $57 \%$. The lower two lines are the RH for upstairs (the flatter of the two) and the basement RH showing $61 \%$ around late morning. The thermostat is located above the return in the upstairs level of the house. 


\section{ZE5 Experiment Database}

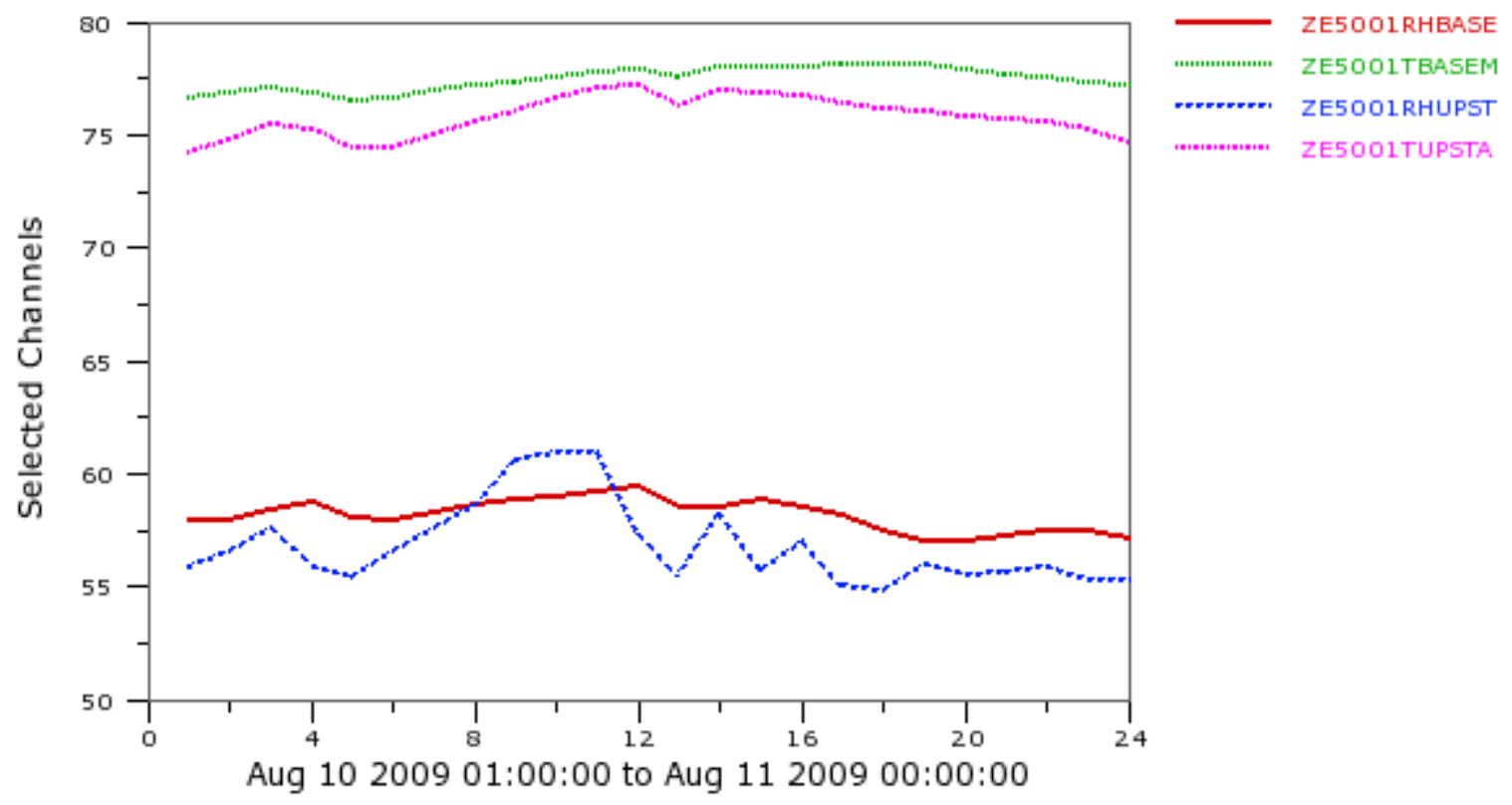

Fig. A.3. Hourly temperatures and relative humidity upstairs and down in ZEH5 on August 10, 2009.

Figure A.4 shows the kilowatts per hour for the GHP, the compressor, and total. The bottom curve (labeled PWGRLP) shows only the pump energy, the second curve is the sum of the pump and the compressor (DAT001). The remaining area under the top curve is the circulating fan energy. Four days of data are shown from August 7-August 10, 2009. The GHP on August 10 used $4 \mathrm{kWh}$ for the pump, $21 \mathrm{kWh}$ for the compressor, and $4 \mathrm{kWh}$ for the fan for a total of $29 \mathrm{kWh}$ to condition this house. This is comparable to a very similarly sized $\left(2500 \mathrm{ft}^{2}\right)$ house in the nearby Campbell Creek community which on this same day used only $16 \mathrm{kWh}$. This house has a SEER 16,2 ton air-source heat pump and used almost half the energy needed for ZEH5. The thermostats in both houses were set at $76^{\circ} \mathrm{F}$.

Figure A.5 shows the geothermal source heat pump monthly kilowatt hour measurements for 2007, 2008 and 2009 compared with "best model" (BA prototype model of ZEH5) and with a calibrated model using the actual measured internal loads and an EER of 6.5 instead of the 15.5 used in the "best model." The 6.5 EER model fits the 2009 measured data well.

The monthly energy consumption values in Table A. 2 are based on hard measurements during November 2008-October 2009, when 6 to 9 people were living in this house. The unfinished lower level was occupied full time on Sept. 1, 2009 after being finished out with open living room, dining room and kitchen, laundry room, bathroom, and two bedrooms. The actual energy cost to the homeowners was $\$ 1.58 / \mathrm{d}$. If the cooling performance of the GHP had been 15.5 as expected, this daily cost would have been $\$ 1.25 / \mathrm{d}$. 


\section{ZE5 Experiment Database}

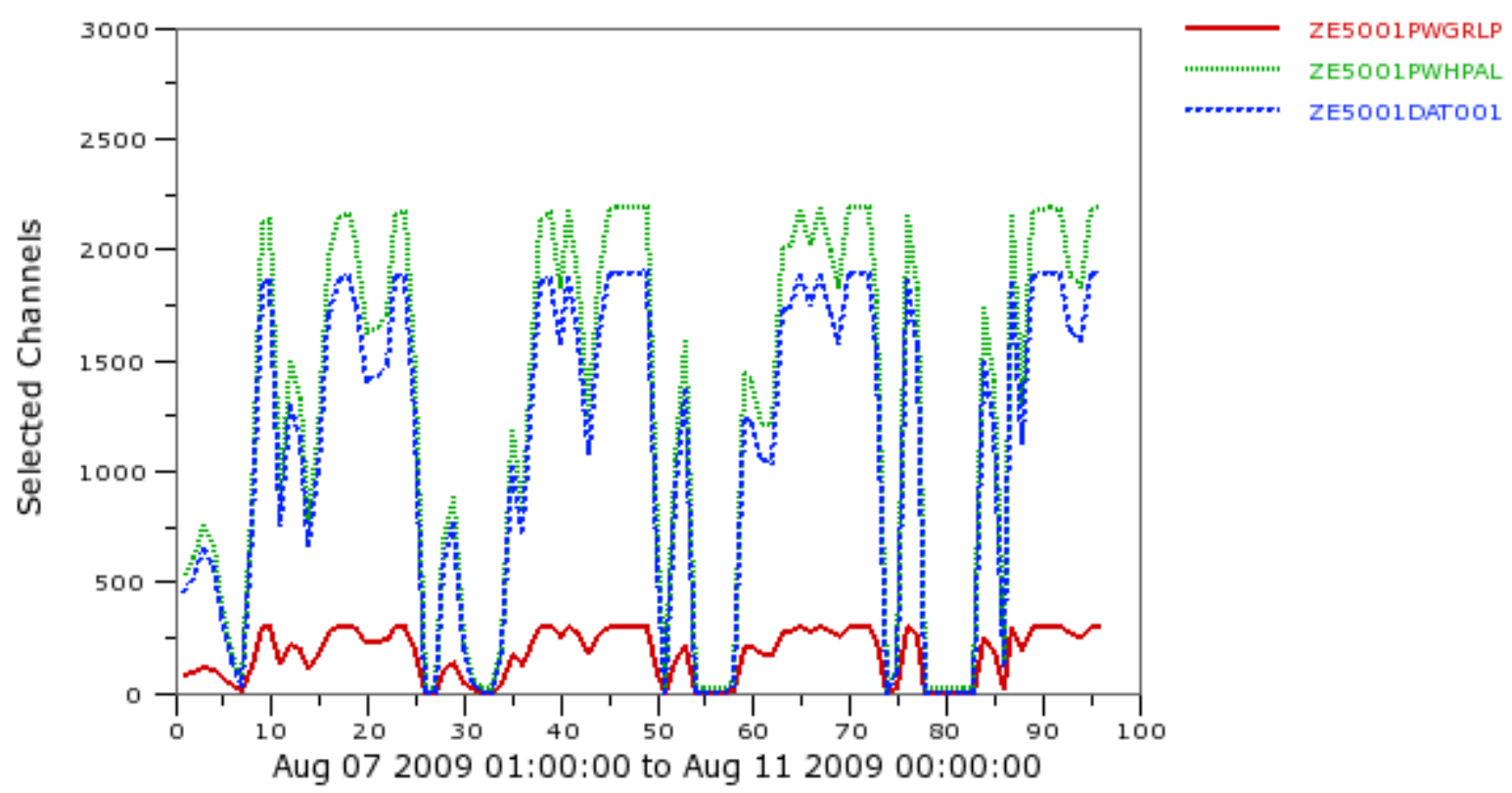

Fig. A.4. Geothermal heat pump energy needed for the pump, compressor, and fan on 4 days in August 2009.

\section{Heat Pump Monthly kWh}

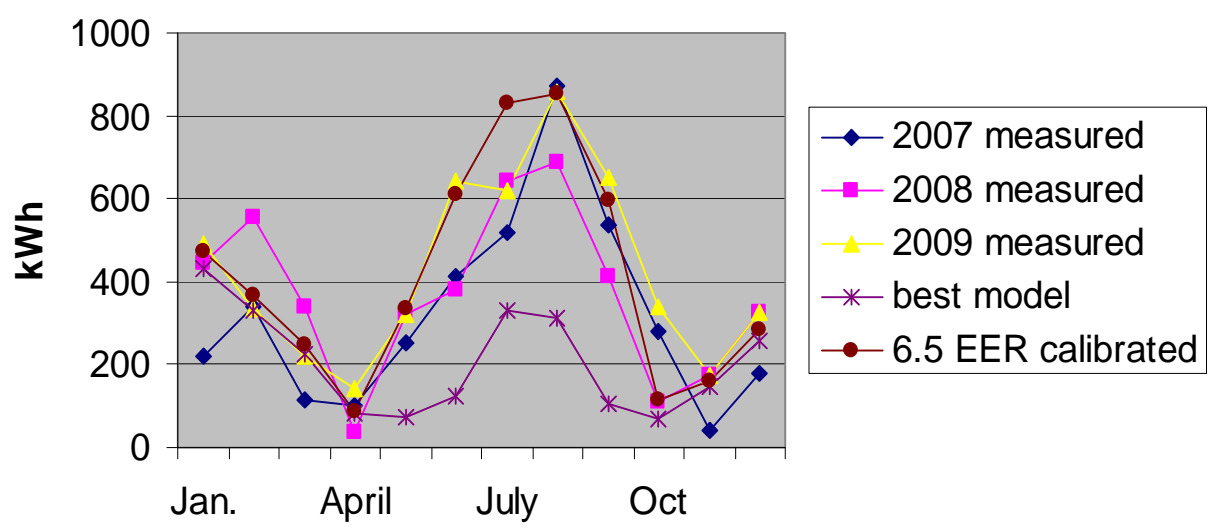

Fig. A.5. Geothermal heat pump measured monthly kWh for 2007, 2008, and 2009 compared with "best model" (BA prototype model of ZEH5) and with a calibrated model using the actual measured internal loads and an EER of 6.5 instead of the 15.5 used in the best model. 
Table A.2. ZEH5 two-story and measured energy use and annual cost breakdown, November 2008-October 2009

\begin{tabular}{lccccccc}
\hline Month & $\begin{array}{c}\text { Space heat } \\
(\mathbf{k W h})\end{array}$ & $\begin{array}{c}\text { Space cool } \\
(\mathbf{k W h})\end{array}$ & $\begin{array}{c}\text { Solar WH } \\
\text { backup } \\
(\mathbf{k W h})\end{array}$ & $\begin{array}{c}\text { Other } \\
(\mathbf{k W h})\end{array}$ & $\begin{array}{c}\text { Total } \\
(\mathbf{k W h})\end{array}$ & $\begin{array}{c}\text { Solar } \\
\text { Generation } \\
(\mathbf{k W h})\end{array}$ & $\$$ \$d \\
\hline Measured & 1693 & 3430 & 791 & 6990 & 12,704 & 3152 & \\
Annual cost $^{a}$ & $\$ 169$ & $\$ 343$ & $\$ 79$ & $\$ 699$ & $\$ 1270$ & $-\$ 693$ & $\$ 1.58$ \\
\hline
\end{tabular}

${ }^{a}$ Residential rate $\$ 0.10 / \mathrm{kWh}$, solar buyback of $\$ 0.22$.

On October 30, 2009, a WaterFurnace technician inspected the geothermal heat pump (GHP). The GHP was turned on and lowered $5^{\circ} \mathrm{F}$ from $76^{\circ} \mathrm{F}$ to $71^{\circ} \mathrm{F}$, which forces the unit into cooling mode. The entering water temperature was measured at $69^{\circ} \mathrm{F}$ and the leaving water temperature at $76.1^{\circ} \mathrm{F}$. The corresponding water loop pressures taken at the unit were 25.2 psi leaving and 30.9 psi entering - a pressure difference of $5.7 \mathrm{psi}$, which WaterFurnace technical support translated to a flow of $9 \mathrm{gpm}$. The measurements on the air side were $73^{\circ} \mathrm{F}$ on the return and $64^{\circ} \mathrm{F}$ on the supply after running for about $10 \mathrm{~min}$. The refrigerant was $124 \mathrm{psi}$ on the suction side and $240 \mathrm{psi}$ on the liquid side. The subcooling was measured at $7^{\circ} \mathrm{F}$ and the superheat $18^{\circ} \mathrm{F}$. The WaterFurnace technician determined that a small amount $(9 \mathrm{oz})$ of $410 \mathrm{~A}$ refrigerant should be added (manufacturer's specifications state that this unit should contain $66 \mathrm{oz}$ ).

After the charge, the suction side pressure was $137 \mathrm{psi}$ and the liquid side $250 \mathrm{psi}$. The subcooling went from $7^{\circ} \mathrm{F}$ to $8^{\circ} \mathrm{F}$ and the superheat remained at $18^{\circ} \mathrm{F}$. The water temperature delta $\mathrm{T}$ (difference) between the entering and leaving went from $5^{\circ} \mathrm{F}$ to $7^{\circ} \mathrm{F}$, but the WaterFurnace technician believed this should have been closer to $10^{\circ} \mathrm{F}$. The temperature difference on the air side remained the same as before the charge, $11.2^{\circ} \mathrm{F}$. This had a $71.2^{\circ} \mathrm{F}$ return side and a $60^{\circ} \mathrm{F}$ supply. According to the technician, a $20^{\circ} \mathrm{F}$ delta $\mathrm{T}$ should have been attainable. However, after these diagnostic tests were run, it was concluded that there was no major problem with the GHP. On November 6, 2009, the ball valve was installed in the water loop and flow reduced to $6 \mathrm{gpm}$. The entering water temperature was $72.7^{\circ} \mathrm{F}$ and the leaving water temperature was $82.7^{\circ} \mathrm{F}$ (delta $\mathrm{T}$ of $10^{\circ} \mathrm{F}$ ). The entering water pressure was 39.8 psi and the leaving water pressure was 37.1 (delta $\mathrm{P}$ of 2.7). The reduced pressure corresponded to a lower flow of about $6 \mathrm{gpm}$. At this point it was felt that all is well with the ground loop. The return air temperature was $72.2^{\circ} \mathrm{F}$ and the leaving air temperature was $60.9^{\circ} \mathrm{F}$ (delta $\mathrm{T}$ $11.3^{\circ} \mathrm{F}$ - still well below the desired delta $\mathrm{T}$ of $20^{\circ} \mathrm{F}$ across the coil in the AC mode). On November 11, 2009, the prime suspect to the units' poor performance was that the thermo static expansion valve (TXV) was "sticking." After a WaterFurnace technical inspection, on December 7, 2009, it was suggested that the TXV should be replaced. After the replacement, which was covered under warranty, the homeowner agreed to allow monitoring of the unit for one more year.

In June 2010, problems with the heat pump finally resulted in a homeowner complaint . WaterFurnace covered under warranty the TXV replacement and a leak in the indoor coil, which had caused the slow refrigerant leak. ORNL checked the status of the unit to confirm that the sticking of the TXV only during the cooling season was the cause of the poor performance. The unit was forced into the cooling mode by dropping the thermostat setting from $76^{\circ} \mathrm{F}$ to $71^{\circ} \mathrm{F}$. The leaving outlet ground loop pressure was $26.5 \mathrm{psi}$ and the entering loop pressure $30.0 \mathrm{psi}$. After a continuous $30 \mathrm{~min}$ of measurement, the delta $\mathrm{P}$ was indeed 3.5. The temperature difference of the ground loop in and out of the unit after $30 \mathrm{~min}$ of operation was measured at $6.8^{\circ} \mathrm{F} .\left(91.1^{\circ} \mathrm{F}-84.3^{\circ} \mathrm{F}\right)$. The delta $\mathrm{T}$ started out at $4^{\circ} \mathrm{F}$. It is not entirely clear why the GHP cooling performance was so low. The refrigerant super heat initially was measured at $8^{\circ} \mathrm{F}$ and after $30 \mathrm{~min}$ dropped to $6.5^{\circ} \mathrm{F}$. The subcooling initially was $14^{\circ} \mathrm{F}$ and after $30 \mathrm{~min}$ of operation in the cooling mode dropped to $12^{\circ} \mathrm{F}$. After $30 \mathrm{~min}$ of cooling the return air side temperature was $71.3^{\circ} \mathrm{F}$ and the supply air temp from the unit in the supply plenum was $58.6^{\circ} \mathrm{F}$. The temperature difference of almost $14^{\circ} \mathrm{F}$ was determined to be satisfactory and confirmed that the unit operational problems had been resolved satisfactorily. 
Data collection for this house was terminated in July 2010, and there have been no homeowner complaints of the horizontal ground loop heat pump not meeting the cooling and the heating needs of the upstairs and downstairs living units. On average this house had eight occupants, five living upstairs and three downstairs. The unit was checked several times for refrigerant charge throughout the 2010 summer cooling season. Besides a faulty TXV and a slow refrigerant leak, there was a major renovation for the last year of data collection when the unit was converted from a single-family houses to a duplex. This renovation could have contributed to the GHP issues for several reasons.

(1) During renovation, doors and windows were likely open more often than usual to vent dust and dry paint.

(2) In the beginning of the summer the occupants had set the thermostat at $78^{\circ} \mathrm{F}$ during the day, turning it down to $75^{\circ} \mathrm{F}$ at 17:00. This daily change may have forced long run times on the loop, which possibly raised the temperature of the soil around the pipe more than if the unit had been operated more consistently.

(3) The house occupancy varied from six to 9 throughout the test period. The Building America Benchmark protocol modeling assumes three occupants for a house of this size.

(4) A 4 in. hole for the lower level oven fan was discovered unsealed during construction of the bottom-level living unit. This may also have contributed to a higher uncontrolled air leakage than assumed from the blower door test results $(0.08 \mathrm{ACH}$ at $4 \mathrm{~Pa})$ conducted before occupancy.

(5) The air cycler may have been accidently turned off by the occupants, which would have caused the motorized damper on the 6 in. fresh-air duct to be left in the unenergized open 24/7 mode. This would have increased the fresh-air intake from $50 \mathrm{cfm}$ to $150 \mathrm{cfm}$ when the circulating fan was running. 


\section{APPENDIX B: RESOURCES}

Precut kits (for houses like ZEH5)

- Pacemaker Plastics, http://www.pacemakerbuildingsystems.com/ (ZEH1)

- FisherSIPS, http://www.fischersips.com/ (ZEH2)

- Insulspan, http://www.insulspan.com/ (ZEH3)

- Winter Panel, http://www.winterpanel.com/ (ZEH4)

- Premier Building Systems, http://www.premier-industries.com/ (ZEH5)

\section{Other resources}

http://www.ashchem.com/ascc/ (peel-and-stick tape for SIP seams manufactured by Ashland Chemical)

DuPont Tyvek (www.tyvek.com)

www.atas.com/dutchseam

www.englertinc.com/roofing-panels.aspx?Page=7 (metal roofing)

Www.unirac.com/s5.htm (clips for solar modules)

www.andersenwindows.com (energy efficient windows)

http://www.igshpa.okstate.edu/ (training)

www.waterfurnace.com (geothermal systems)

http://www.ghpc.org/about/how.htm (about geothermal)

www.Aircycler.com (heat pump compressor monitor)

www.energystar.gov/index.cfm?c=fixtures.alp_consumers (about lighting)

www.bigfrogmountain.com/ (photovoltaic/solar modules)

http://solarroofs.com/purchase/documents/060503Sys5InstallManual.pdf. (solar water heater)

www.guaranteedDryBasements.com (waterproofing) 